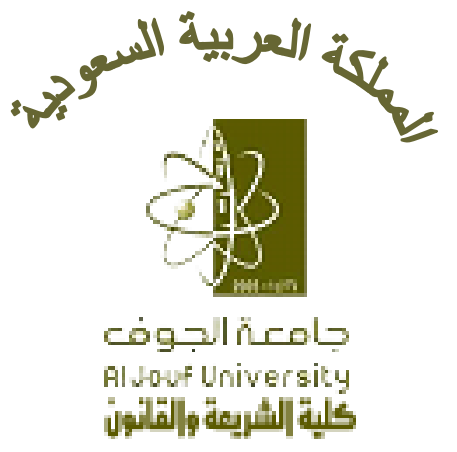

$$
\begin{aligned}
& \text { أحقية المرأة في همارسة التجارة ودورها } \\
& \text { في تصقيق رؤية المملكة .r.r }
\end{aligned}
$$

( دراسة هقارنة بين النظم الوضعية والشريعة الإسلامية )

$$
\text { إعداد }
$$

$$
\text { د. مسعود يوزتس عطوان عطا }
$$

ملدرس القانون التجاري والبحري بكلية الشريعة والقانون - بطنطا - جامعة الأزهر وأستاذ القانون التجاري والبحري المساعد بكلية الشريعة والقانوز بجامعة الجوف

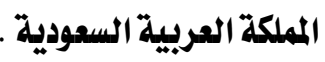


مجلة كلية الدراسات الإسلامية والعربية بنات - دمنهور العدد الثاني - المجلد السابع v.•rم 
"أحقية المرأة في ممارسة التجارة ودورها في تحقيق رؤية المملكة .ب.r ( دراسة مقارنة ...
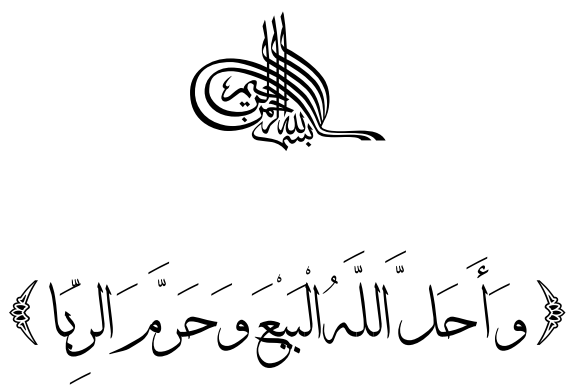

سورة البقرة : من الآية رقم rVO

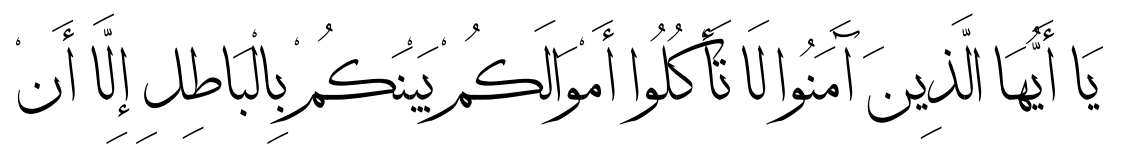

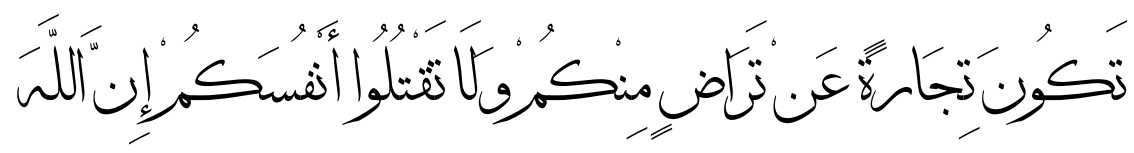

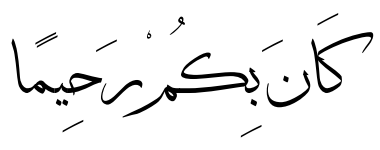

سورة النساء : الآية رقم 9

sY 


\section{\&) إن}

$$
\text { إلى كل امر أة ، إلى الفتيات الطموحات ،،؛ }
$$

إلى الأمهات الفضليات الحانيات 66666،

$$
\text { إلى الر اغبات في الكسب الحلال ،6،؛، }
$$

إلى الزوجات المقدمات على الأعمال ،6،

إلى كل تاجرة أهدى ثمرة هذا البحث . 


\section{مقدمة}

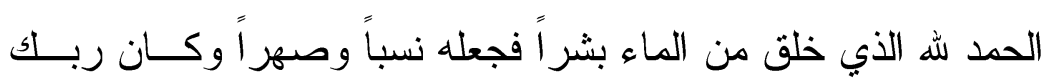

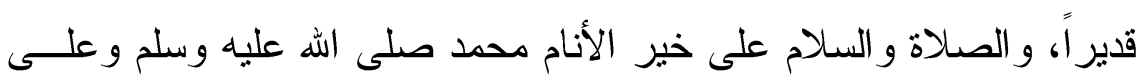
آله وصحبه وسلم.

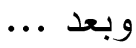

فلقد أولت الشريعة الإسلامية المر أة عنايتها؛ فبعدما كانت مــؤودة و إن تركت فممقته (') أصبحت تثتع بذمة مالية مستقلة مثلها مثل الرجل نماماً

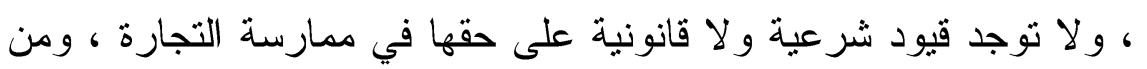
هذا المنطلق فقد أولت رؤية المملكة العربية السعودية .ب .ب م أهمية فائقة

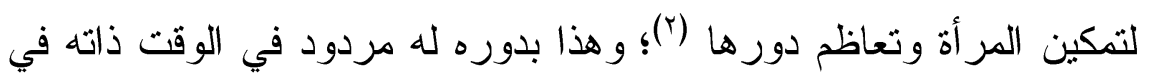
إنجاح هذه الرؤية المباركة وتحقيق أهدافها ، وقد أثبت التاريخ قديما وحديثاً دور المرأة في التجارة ولا أدل على هذا الدور من دور تجارة أم المؤمنين

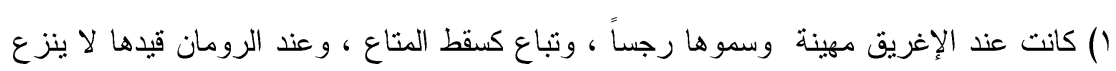

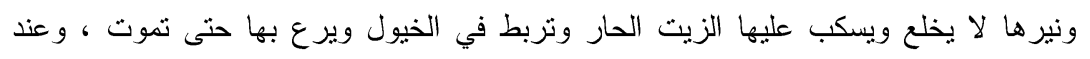

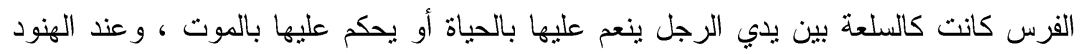

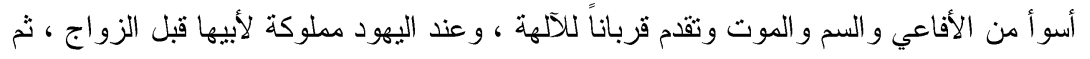

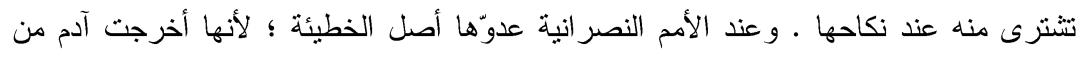

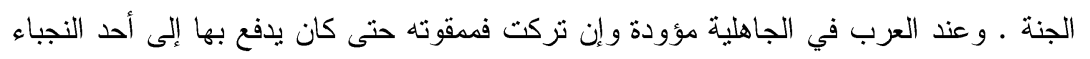

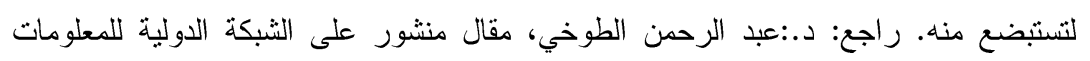
و والمراجع الني أثنار إليها في الموقع التنالي: .http://www.alukah.net/social/0/27156/\#ixzz5CehbwgQu

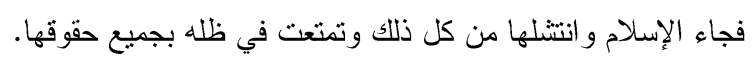

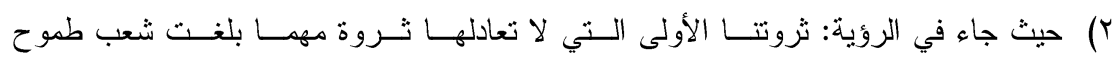

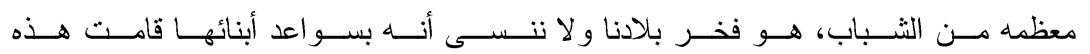

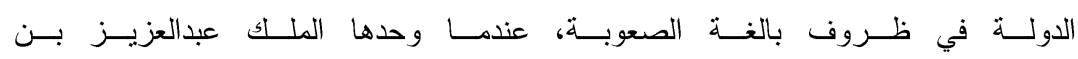

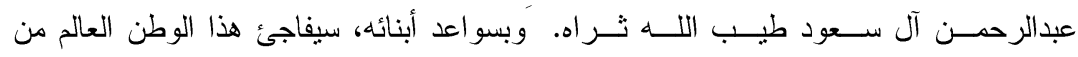


خديجة رضي الله عنها في نشر الدعوة الإسلامية ورعايتها في مهدها الأول

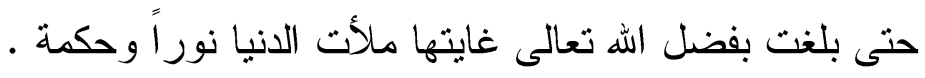

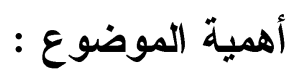

تأثي أهمية الموضوع في أن المر أة تمثل نصف المجتمع ، وعليها مهمة

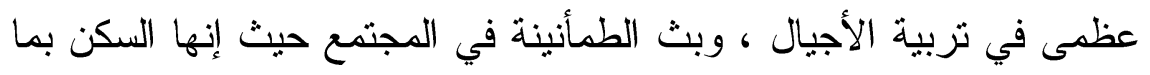

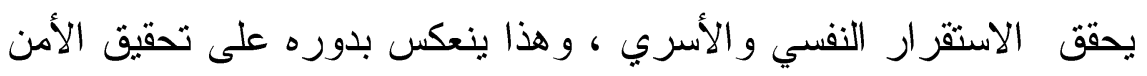

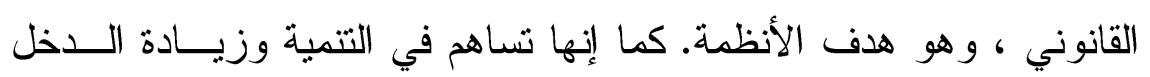

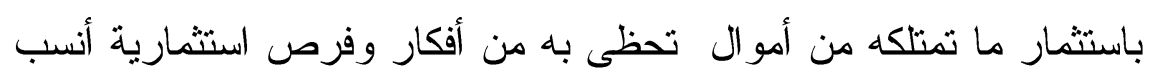

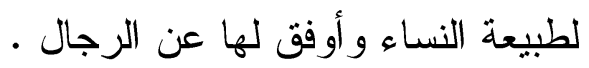

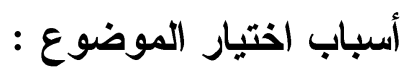

أهيته السابقة ؛ولبيان مدى أحقيتها في ممارسة تجارة منفرده عن وليها

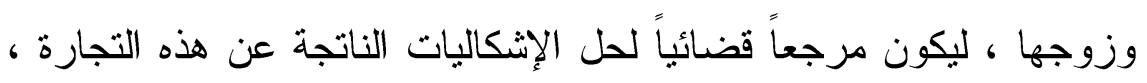

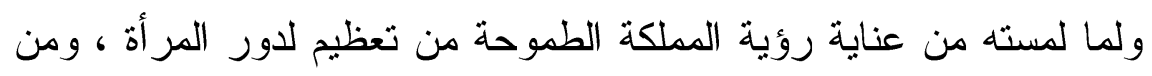

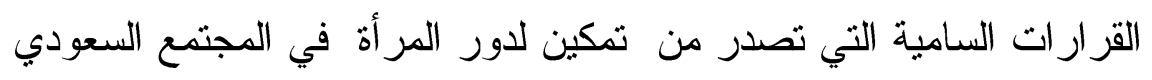

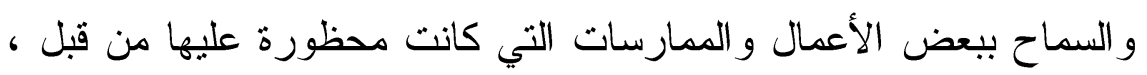

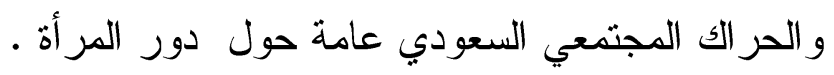

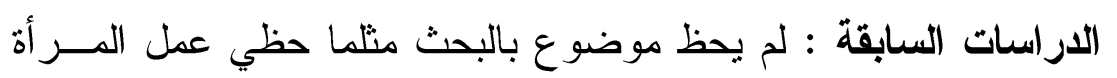

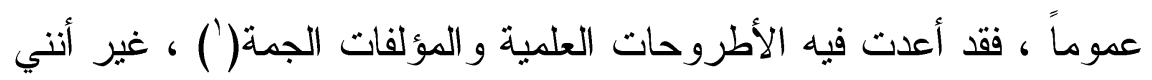

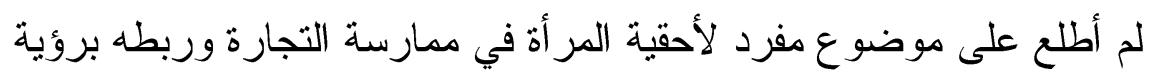

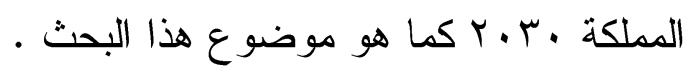

() من ذلك المر اجع التي ترد في ثثايا هذا البحث . 
منهج البحث : يقوم البحث على المنهج الاستقرائي، حيث سبر أحسـداث

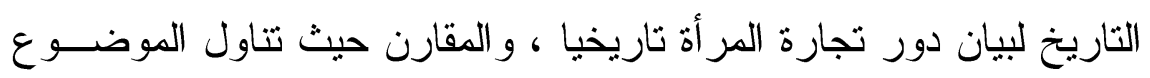
بين النظم الوضعية و الثريعة الإسلامية . لمان

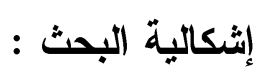

تتمثل في أن المر أة السعودية تحظى بمزيد رعاية و عنايــة طبقـا لأحكام الشريعة الإسلامية الغراء و التيهي سمة المجتمع السعودي بوجه عام

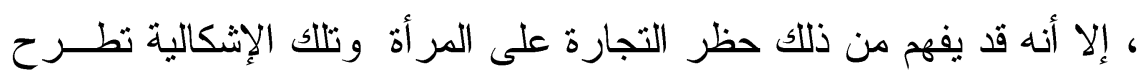
تساؤلات التي يأتي البحث للإجابة عليها وهي: دهي:

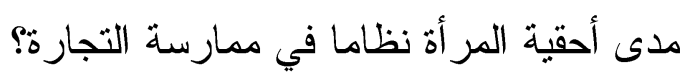
موقف الثريعة الإسلامية من ممارسة المرأة للتجارة؟ مداء

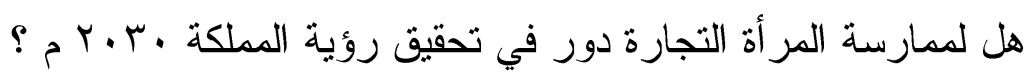
خطة البحث: تشتمل على تمهيد وثلاثة مباحث: تمهيد :الدور التاريخي لممارسة المر أة التجارة. المبحث الأول :عناية النظم الوضعية بأحقية المر أة في ممارسة التجارة المبحث الثاني: موقف الثريعة الإسلامية من ممارسة المر أة التجارة..

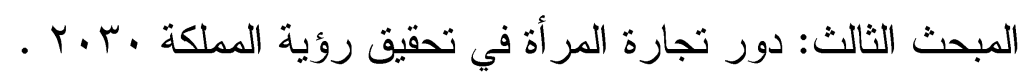




\section{التمهيد}

\section{الاور التاريخي لممارسة المرأة التجارة}

تمهيد وتقسيم : تحفيم

يحفل التاريخ ويشرف بالدور البارز للمر أة في ممارسة التجارة وموقفها

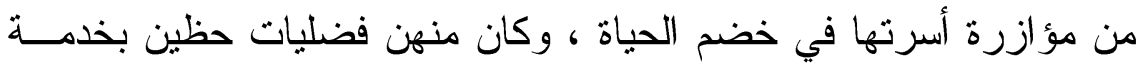

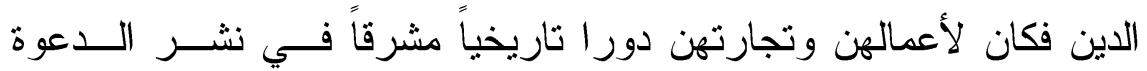

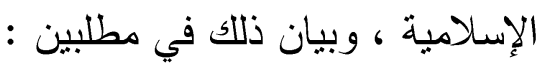

المطلب الأول : ممارسة المر أة التجارة في العصور القديمة المطلب الثاني :الدور التاريخي لتجارة المر أة في نشر الدعوة الإسلامية المطلب الأول

\section{ممارسة المرأة التجارة في العصور القديمة}

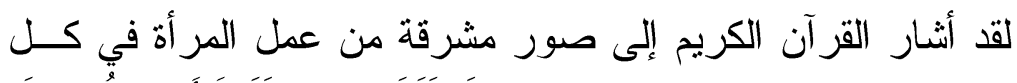

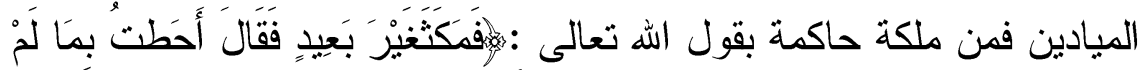

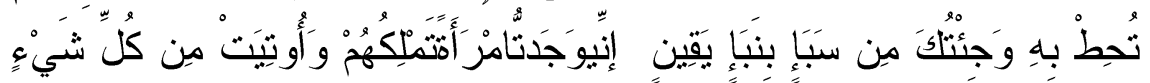

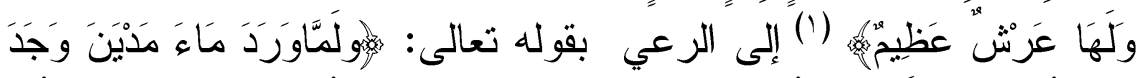

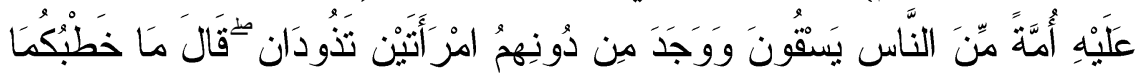

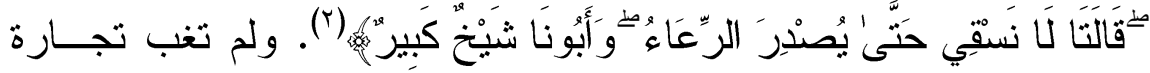
المر أة عن المشهد التاريخي فها هي أم المؤمنين خديجة - رضي الله عنهاء

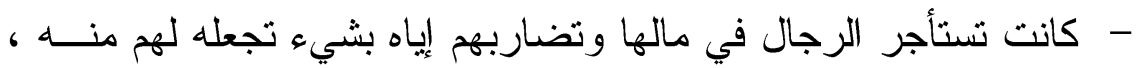

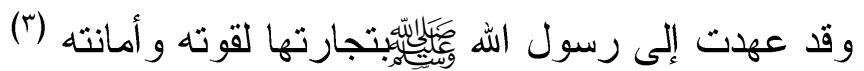
ومن المعلوم أن النساء شقائق الرجال وقد اشتغلت النساء بالتجـــارة فــي

$$
\begin{aligned}
& \text { () سورة النمل ، الآية (Y - ك r (Y ). }
\end{aligned}
$$

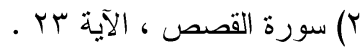

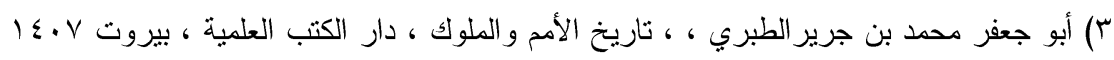

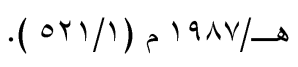


الأسواق ، وخاصة بعد عهد الدولة القديمة ، ومناظر الأسواق التي سجلتها النقوش الجدارية في معابد الدولة القديمة نساء يجلسن على ضفة نهر النيل

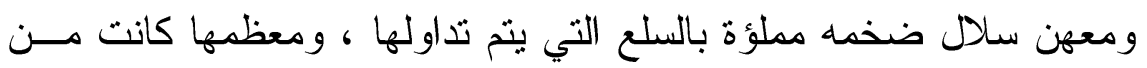
منتجات الريف المصري ، و لا شك أن عمل النساء الريفيات في حاضــرنا

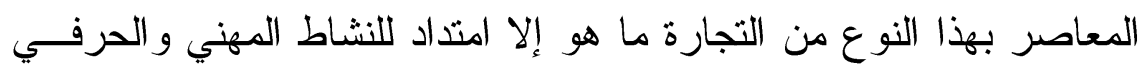
الكبير الذي عرفت به نساء الريف في العصور القديمة('). وللمر أة السعودية دوراً اجنماعياً حيوياً منذ القدم ، بسبب أن الرئ الرجل كان يترك البيث لفترة طويلة سعياً لطلب الرزق و الجهاد في سبيل الهه ، وكانت تتولي توفير الرعاية التامة للعائلة (؟).

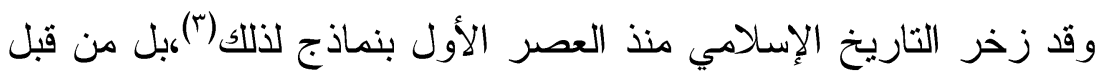

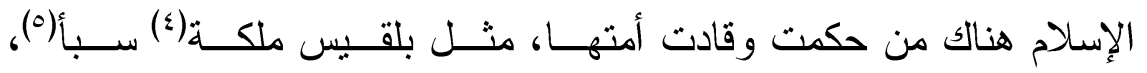

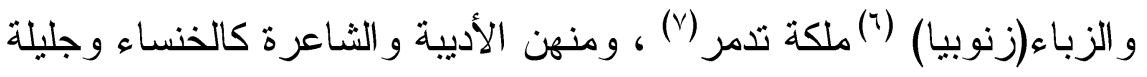
بنت مرة ، و عاتكة بنت عبد المطلب ـ وفي فجر الإسلام كانت خمس نسوه

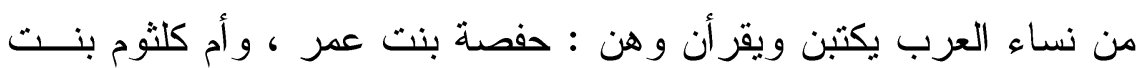

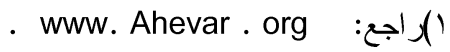

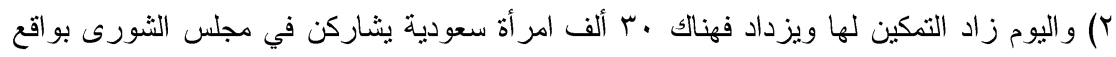

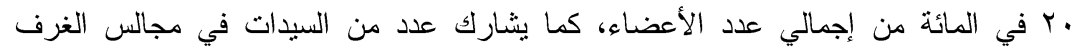
p://www.aleqt.com/2014/07/17/article_868081.ht

$$
\text { التجارية في الرياض وجدة وغير لجما. و راجع: }
$$

r) راجع :المطلب الثاني من المبحث الأول من هذا البحث .

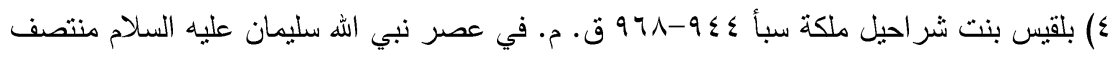

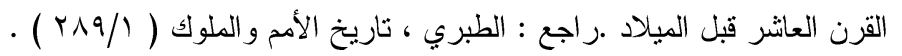

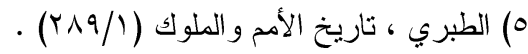

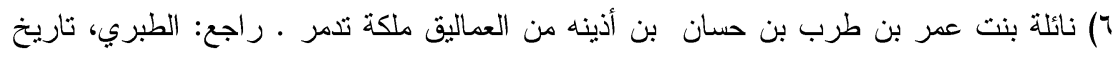

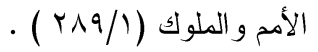

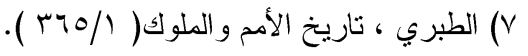


عتبة ، و عائشة بنت سعد ، وكريمة بنت المقداد ، و الثـــفاء بنـــت عبــــالله

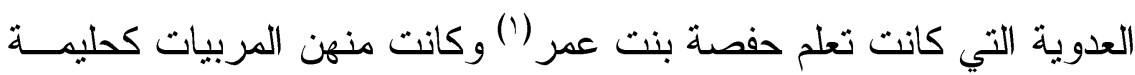

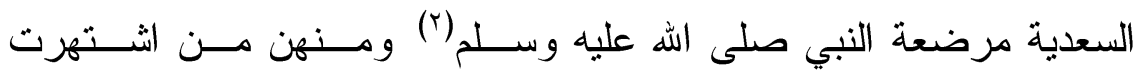
بالصناعة ردينة امر أة السمهري ، وينسب لها الرماح الجيدة (باّ) في العطارة وبيع الطبب منشم من بني غدائة(؛). وبعد الإسلام هناك من النساء من نولت إدارة السوق وهي ليلى بنت عبد الله بن عبد شمس العدوية (0) ومنهن من عملت بصناعة الطب ومداواة النساء أم الحسن بنت القاضي أبي جعفر الطنجالي (־) وأخت الحفيد بن زهر و ابنتها تداوي أهل المنصور (V) ومنهن من أقامت المشروعات المعري العملاقة كفتح الطرق وحفر الآبار و إقامة السدود و إنشاء عديد من القلاع و الحصون

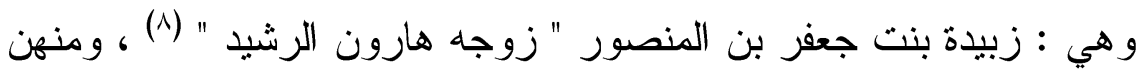

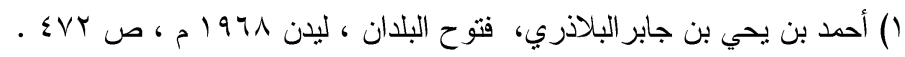

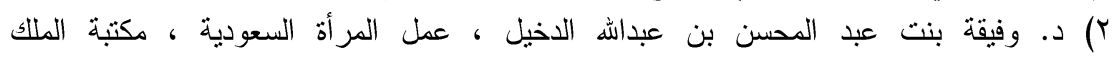

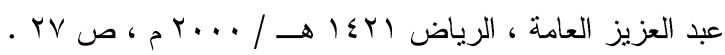

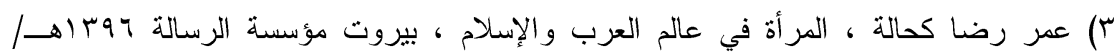

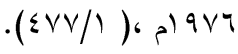

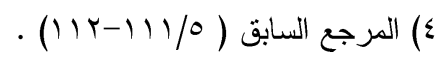

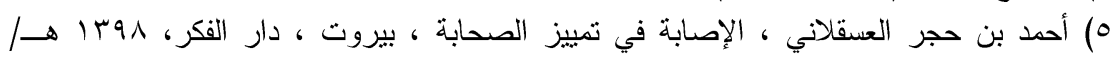

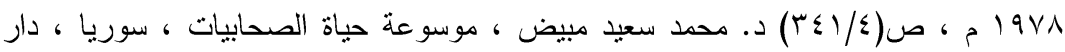

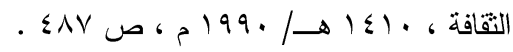

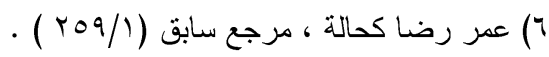

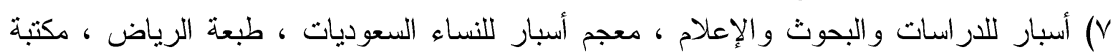

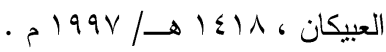

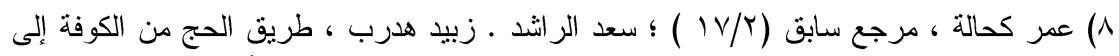

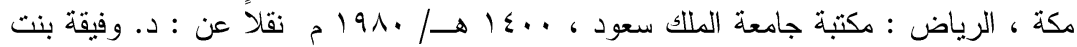

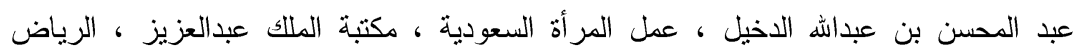

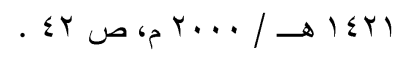




\section{· أحقية المرأة في ممارسة التجارةودورها في تحقيق رؤية المملكة •r+r ( دراسة مقارنة ...}

من اشتهرت بالأعمال الحرفية السقي والخرازة والأعمال المنزلية مثل

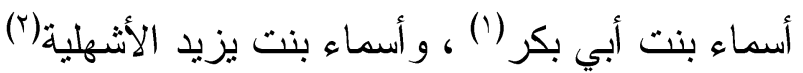
وقد حظيت النساء باحتر ام كبير من قبل المجتمع في المقابـلـل امتثــالاً

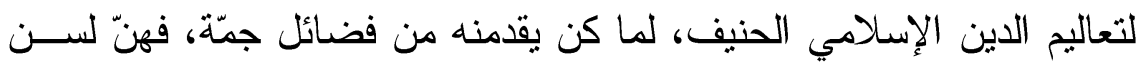

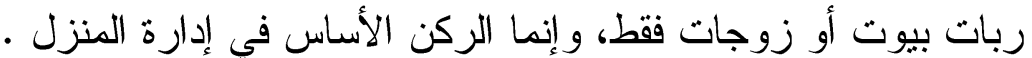

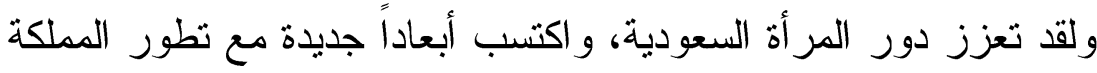

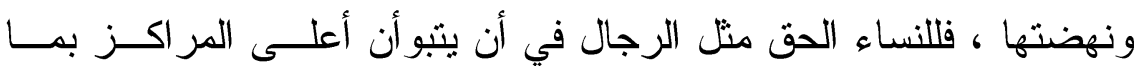

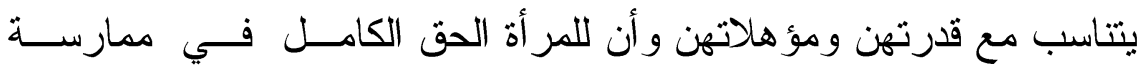
التجارة فضلاً عن التعليم و العمل و الوظائف مثلها مثل الرجال وذللك فــي لكي

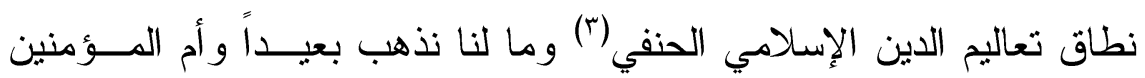
عائشة تتصدق من كسبها وأن أطيب الصدقة ماكان من كسب اليد .

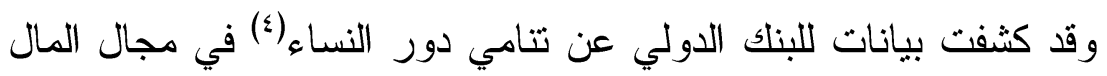

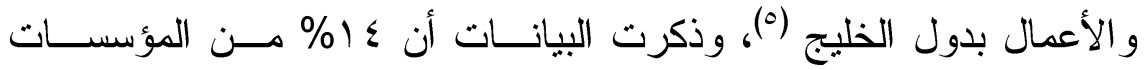

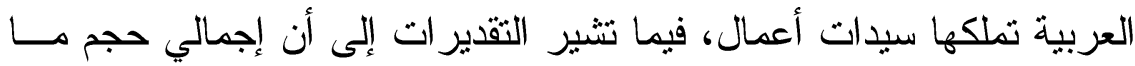

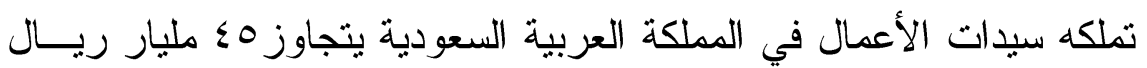

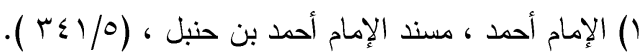

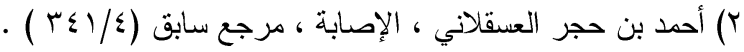

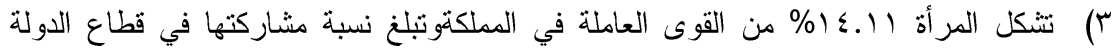

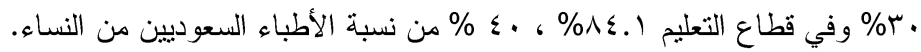

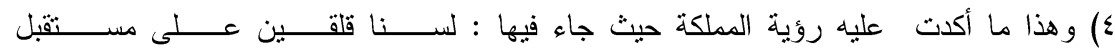

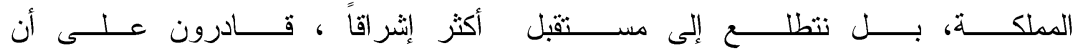

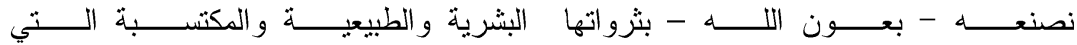

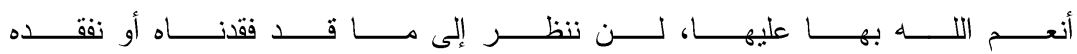

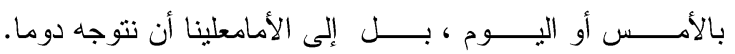
ه م ويترأس مجلس إدارة السوق المالية بالمملكة العربية السعودية امر أة. 


\section{مجلة كلية الدراسات الإسلامية والعربية بنات - دمنهور العدد الثاني - المجلد السابع Vا.+rم}

في البنوك السعودية. كما تبلغ قيمة الاستثمار ات العقارية باسم الســعوديات

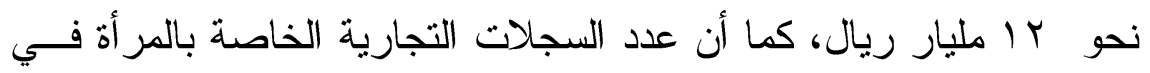
تز ايد مستمر فقد كان عددها بـ ألف سجل في مختلف مناطق المملكة في

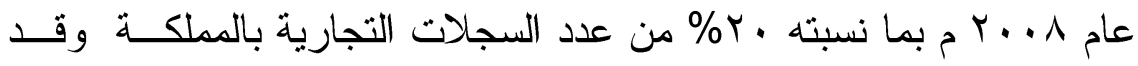

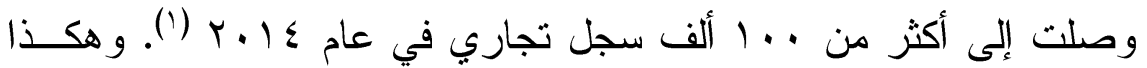

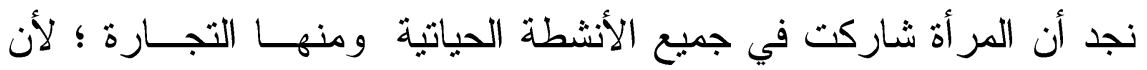
الإسـام حين وضع المر أة موضع المسؤولية منحها حق الكسب الحــلال ،

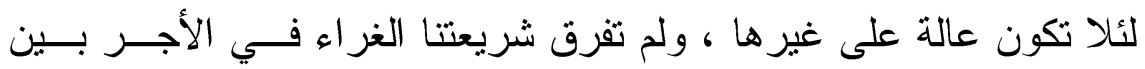

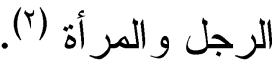

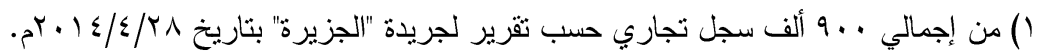

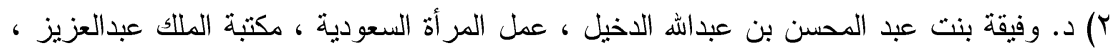

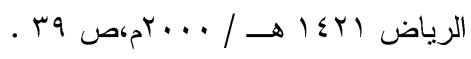




\section{المطلب الثاني}

\section{الاور التاريخي لتجارة المرأة في نشر الدعوة الإسلامية}

للمر أة دور تاريخي مشرق لا يمكن تجاهله (') فهذه مؤازرة أم المــؤمنين

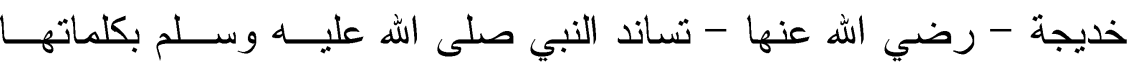

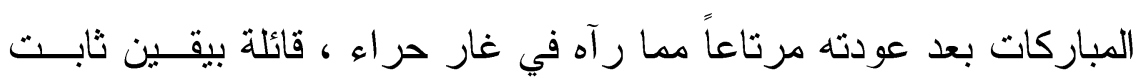

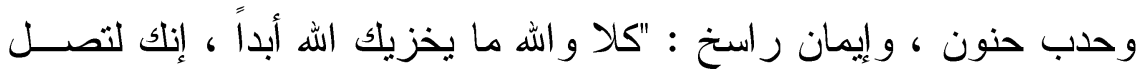

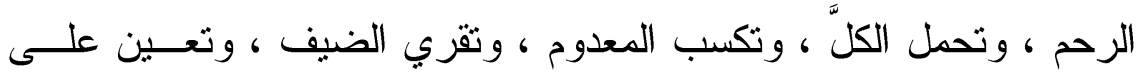

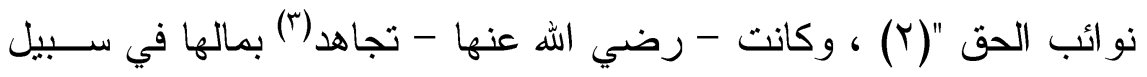

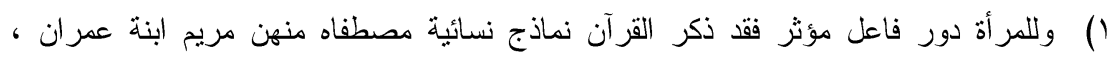

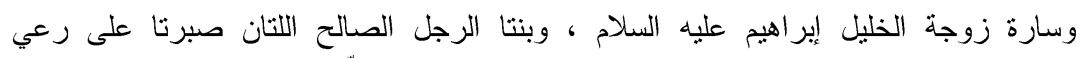

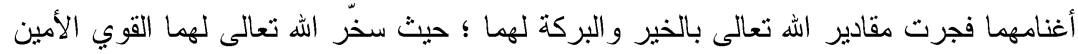

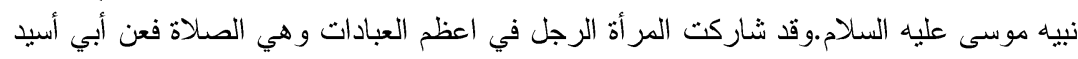

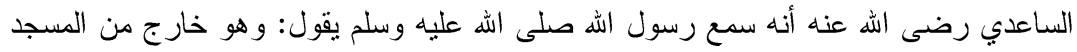

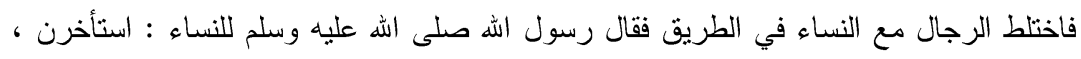

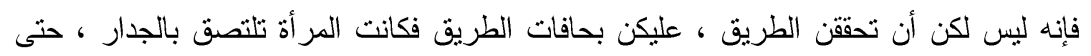

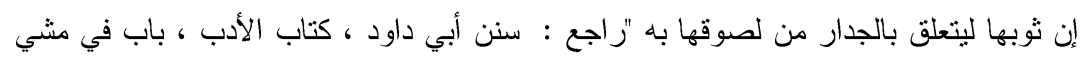

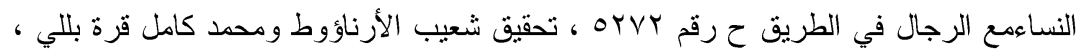

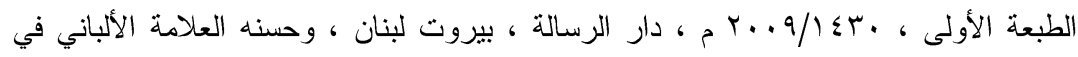

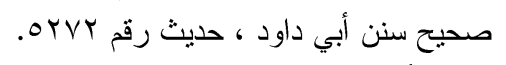

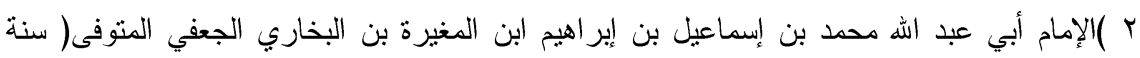

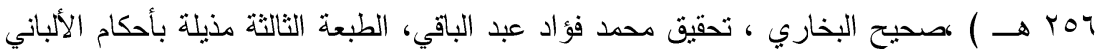

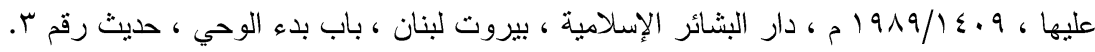

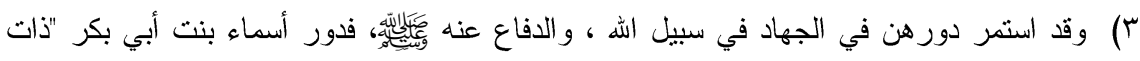

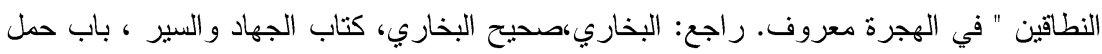

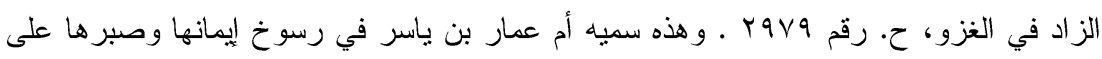

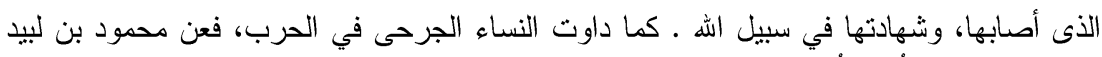

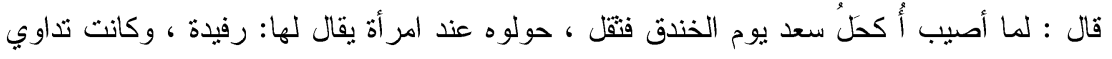

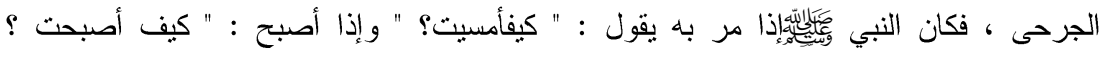

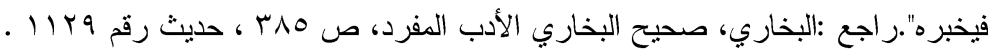


الله وتتفق بسخاء(') رغم حبها الثديدلمالها فقد كانت تـــؤمن أنــهـ عصــب وجودها ، وتاج حياتها وكانت قافلة من عندها تعدل قو افل قــريش كلهـــا ،

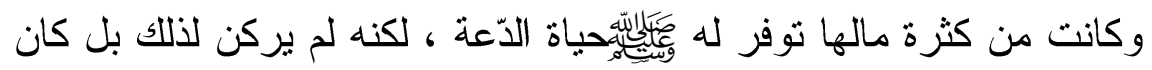
يخرج يتاجر لها في مالها (؟). وقد نزل الوحي ولم يمنعها من تجارتها ، ولم

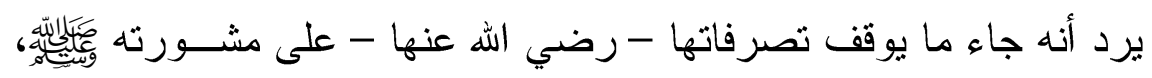

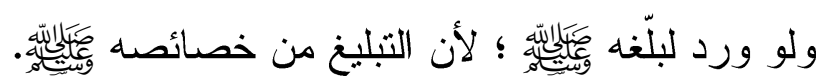

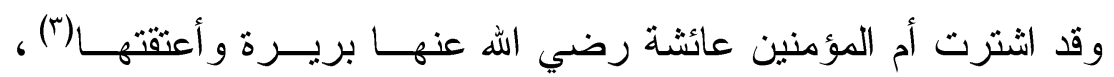
وكانت أم أيمن تتمي أمو الها وتتفق على أسرتها ، وقد باعت أسماء بنت أبي بكر الصديق رضي الله عنهما جارية لها فذخل عليها زوجها وثثن الجارية

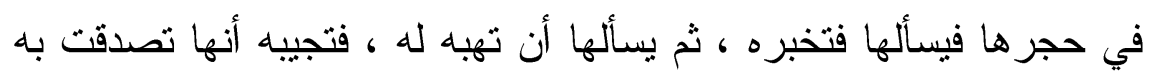

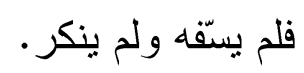

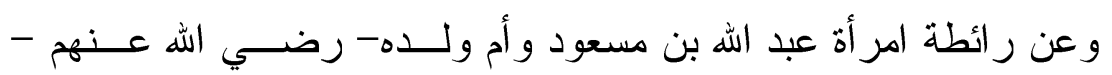
كانت صناعاليد وتتكسب من صنعتها وكانت تنفق على زوجها وولدها مـــا

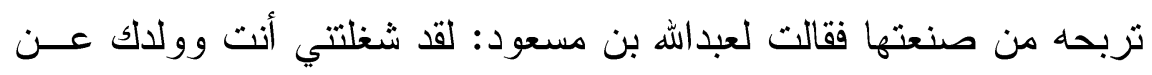

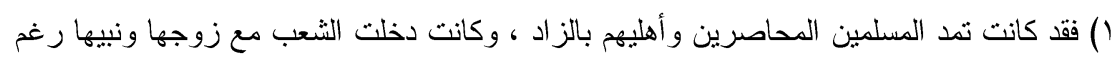

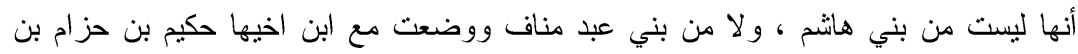

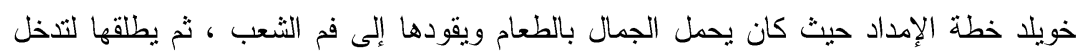

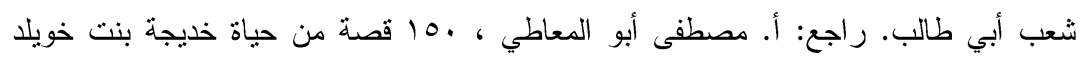

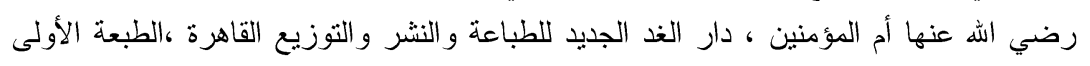

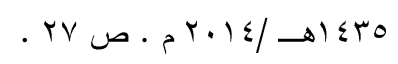

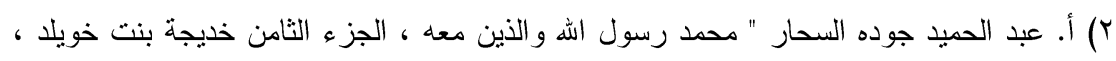

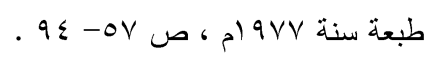

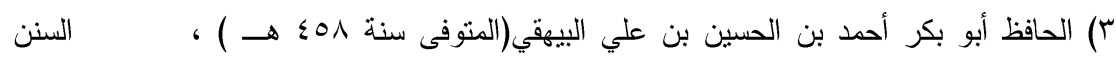

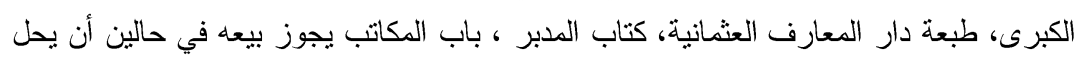

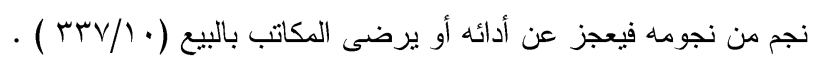


الصدقة، فما استطيع أن أتصدق معكم بشئ، فقال لها عبد الله: و الله ما أحب

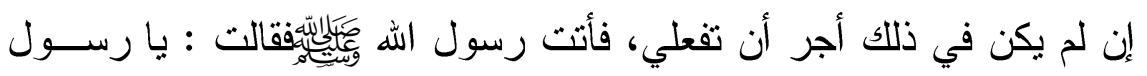

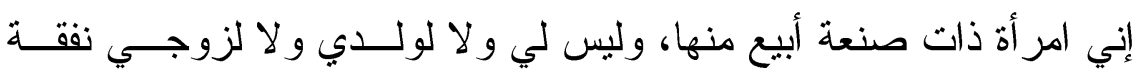
غيرها، وقد شغلوني عن الصدقة ، فما استطيع أن أتصدق بشئ، فهل لـي ولـي

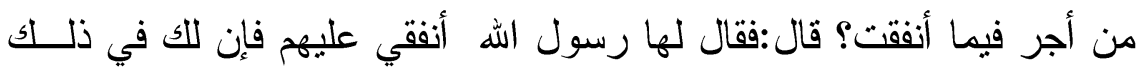

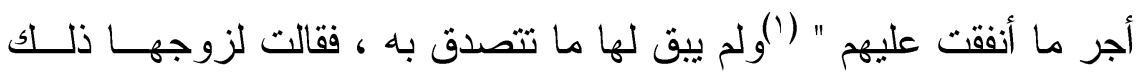

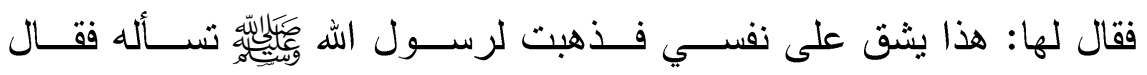
لها: " زوجك وولدك أحق من تصدقت به عليهم " (r). ومن ذلك يثبث أن الصحابيات - رضوان الله عليهن - مارسن التجــارة

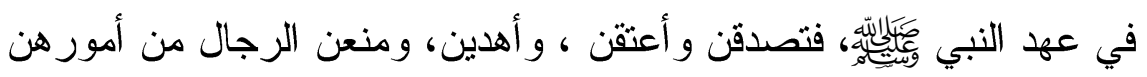

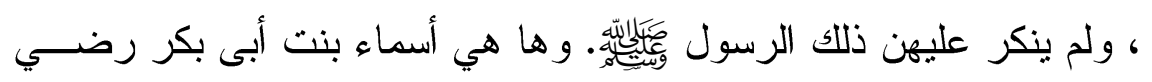

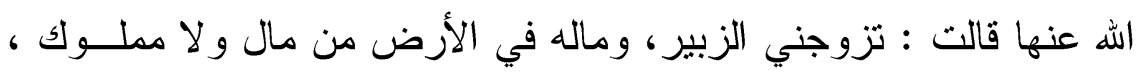

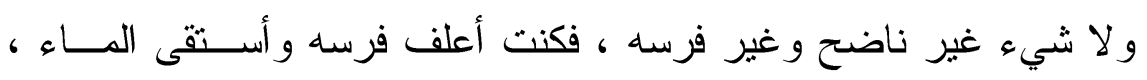
و أخرز غربه و أعجن ، ولم أكن أحسن أخبز ، وكان يخبز جار ات لي هــن فئن

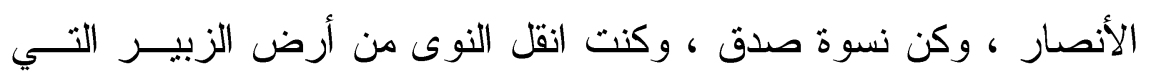

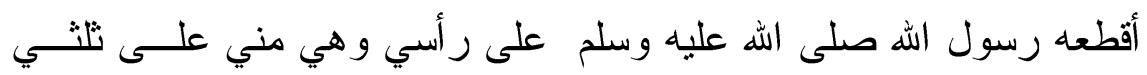

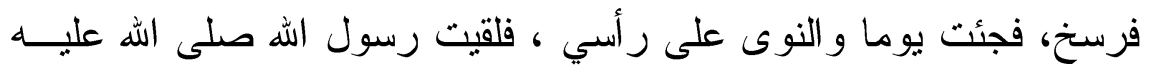

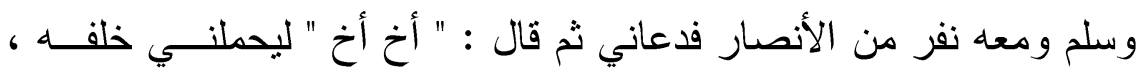
فاستحييث أن أسير مع الرجال، وذكرت الزبير وغيرته وكان أغير الناس،

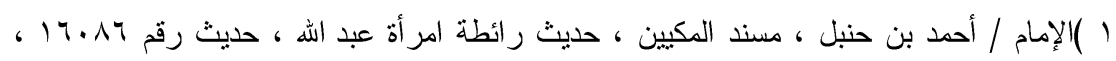

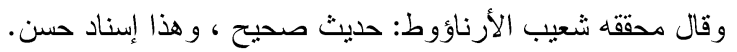

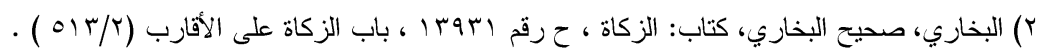


فعرف رسول الله أني قد استحييت فمضى، فجئت الزبيــر فقلــت : لقينـي

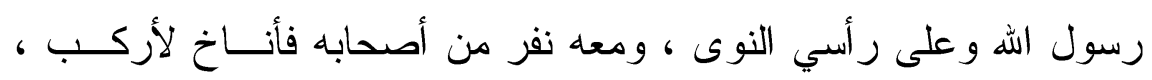

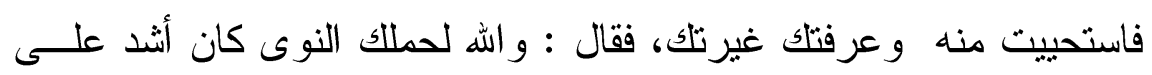
من ركوبك معه، قالت : حتى أرسل أبو بكر بعد ذلك بخادم تكفيني سياسية الفرس فكأنما أعتقني( (1) فهذه امر أة تعمل مع زوجها لمعاثهما.

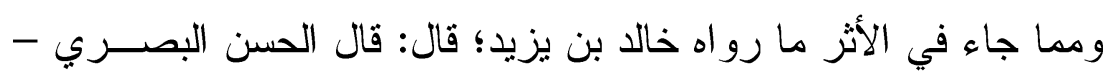

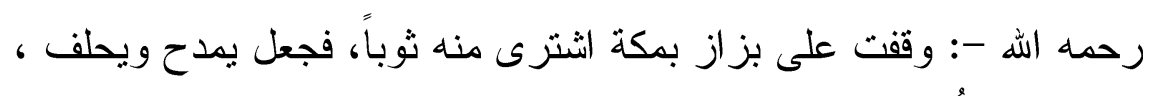

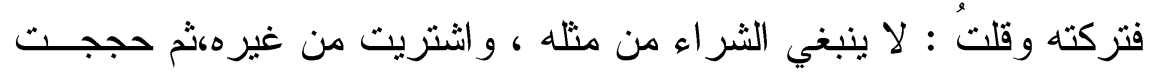

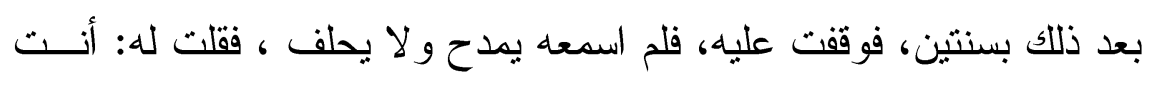

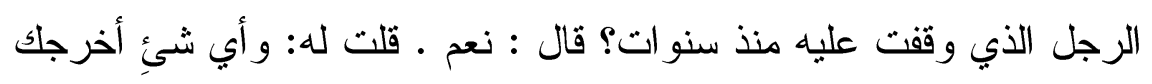

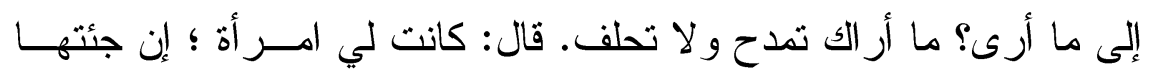
بقليل نزَرته ، و إن جئتها بكثير قلّتنه ، ثم أماتها الله ، فتزوجت امر أة بعدها

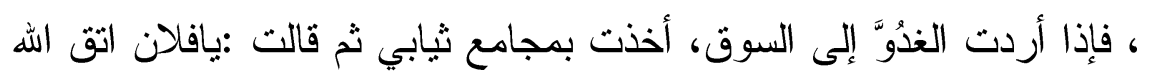

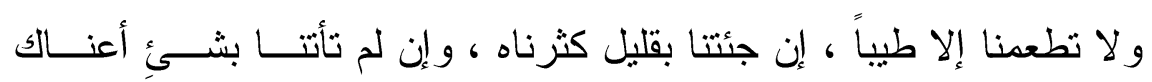

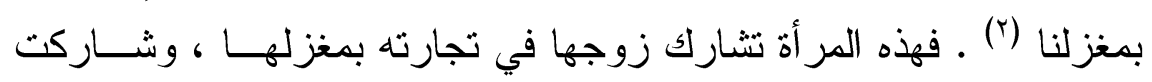
زوجها عملياً في التغلب على مشكلته . فالمر أة نصف المجتمع وتلا النصف الآخر و المجتمع زاخر بأنو اع مـن فئن

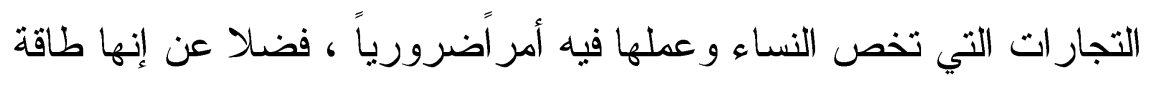
بشرية مثمرة تمثل عو ائد إيجابيه على تتمية المجتمع في مختلف المجالات،

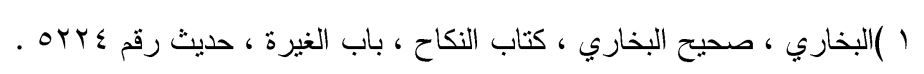

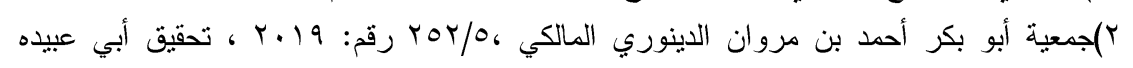

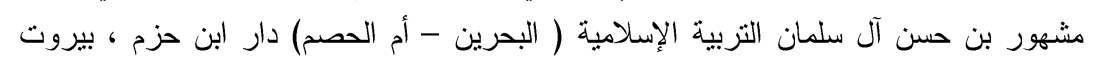

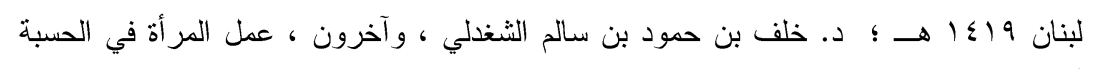

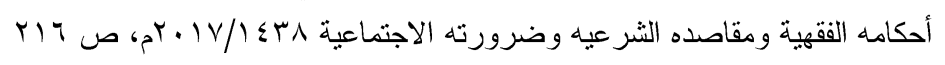


وقد تضطر المر أة المسلمة لتحقيق معاشها الخروج للعمل ، و إن لم تعمـلـل يصيبها ضرر كبير في التز امها بدينها من هدر الحاجات ، إنها بعملها فـي

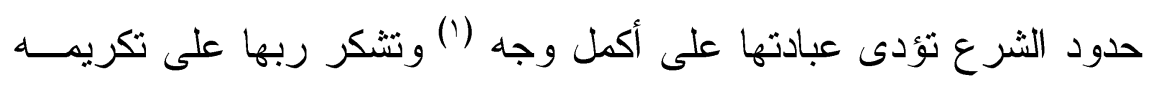
إياها ، و تلبى نداء الفطرة التي فطر ها الله عليها وتكليفه سبحانه وتعالى لها لها بالعمل و البعد عن البطالة .

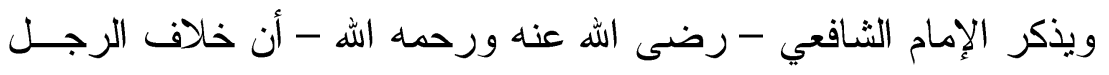

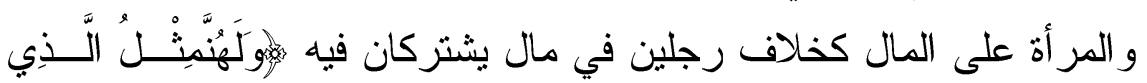

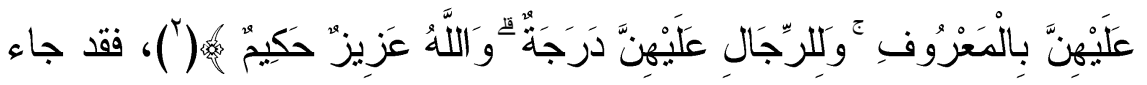
في الأم : إذا اختلف الرجل و المر أة في متاع البيت الذي هما فيه ساكنان وقد افترقا أو لم يفترقا أو ماتاأو مات أحدهما فاختلف ورثثها أو ورثة أحدهما

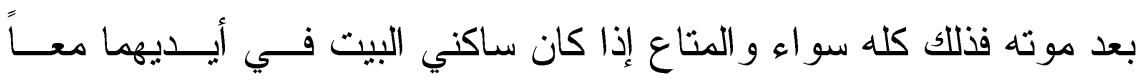
فالظاهر أنه في أيديهما كما تكون الدار في أيديهما أو في يد رجلين فيحلف

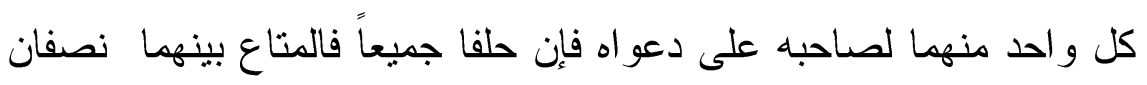

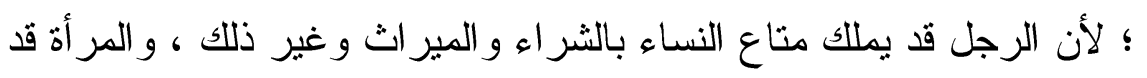
تملك متاع الرجل بالثر اء و الميراث و غير ذلك فلما كان هذا ممكناً وكـــان

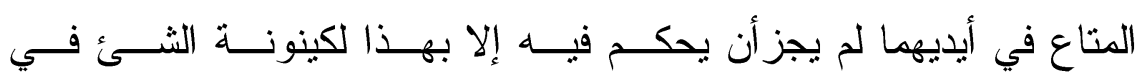

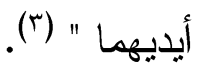

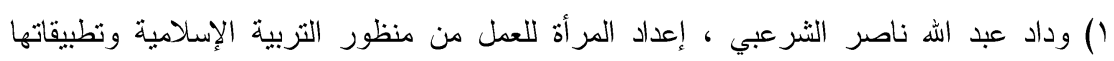

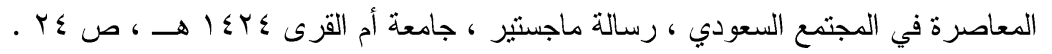

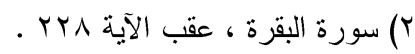

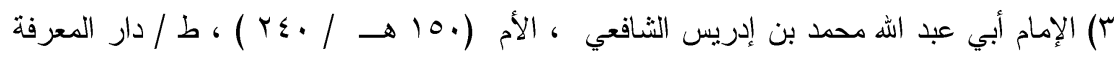

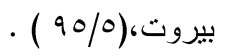




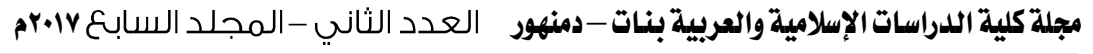

\section{المبحث الأول}

عناية النظم الوضعية بأحقية المرأة في ممارسة التجارة

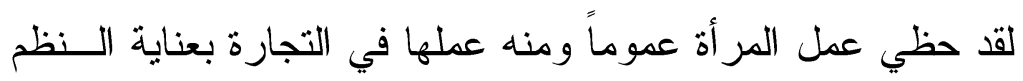
سو اء في المعاهدات و المو اثثي الدولية ، أم في النظم الداخلية للدول ؛ وذللك لأهمية مشاركتها في تحقيق الدخل واستثمار أمو الها ، فضلاً عن إنها طاقة بشرية مثمرة تمثل عو ائد إيجابيه على تتمية المجتمع في مختلف المجالات، وبيان ذللك في مطلبين.

المطلب الأول : أحقية المر أة في ممارسة التجارة في المعاهدات و المو اثيــق الدولية

المطلب الثاني : أحقية المر أة في ممارسة التجارة في النظم الداخلية . 


\section{المطاب الأول}

\section{أحقية المرأة في ممارسة التجارة في المعاهدات والمواثيق الدولية}

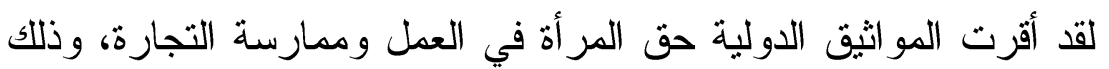

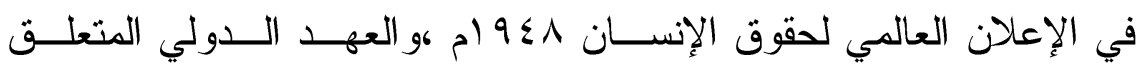
بالحقوق الاقتصادية و الاجتماعية والثقافية ، و العهد الدولي المتعلق بالحقوق المدنية و السياسية و البروتوكول الاختياري الملحق به وقد وقعت المصــادقة

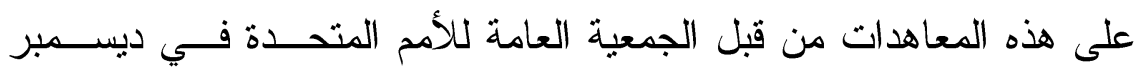
- م) 977

وكذلك اتفاقية القضاء على كافة أشكال التمييز ضد المر أة الصــادر فـي

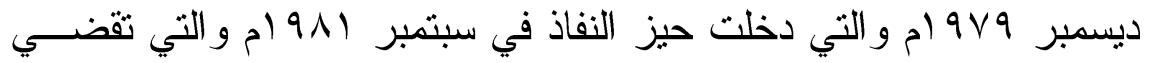

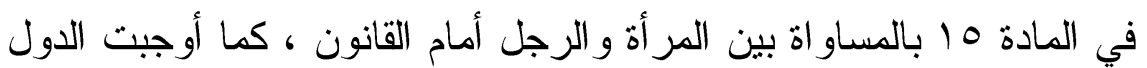
الأطر اف أن تمنح المر أة في الثؤون المدنية أهلية قانونية مماتلـــة لأهليـــة فئة الرجل تماماً ، وأن تساوي بينهما في فرض ممارسة تلك الأهلية بحيث تكفل للمر أة بوجه خاص حقوقاً مساوية لحقوق الرجل في إبــرام العقــود و إدارة

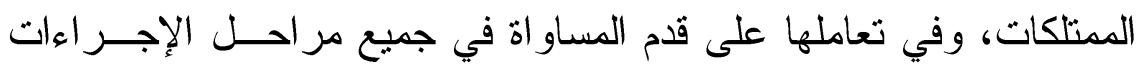

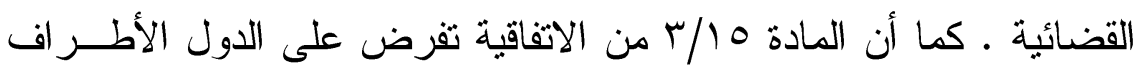

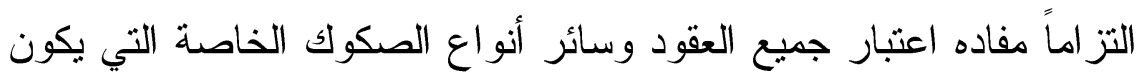
لها أثز قانوني يستهدف الحد من الأهلية القانونية للمر أة باطلة و لاغية .

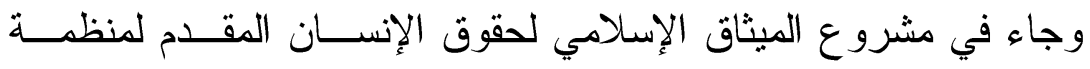

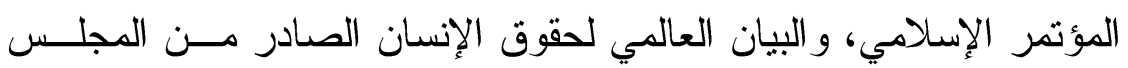
الإسلامي العالمي في 9 اسبتمر سنة الهوام المادة 17 للإنسان الحق في 
التجارة المشروعة على ألا يحتكر أو يغش أو يضر بالمسـتهلك ('). ذلـــك دون تقرقة بين الرجل و المر أة .

وتتص المادة ماج في بند الحقوق الاقتصادية على أن : الملكبـــة

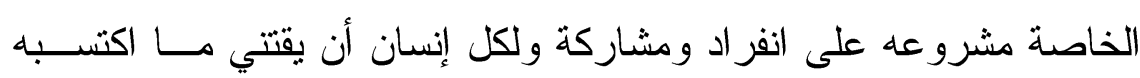
بجهده وعمله.

وقد آتت هذه المو اثيق و البرونوكو لات و المو اثيق أُكلها فقد كثفت بيانات

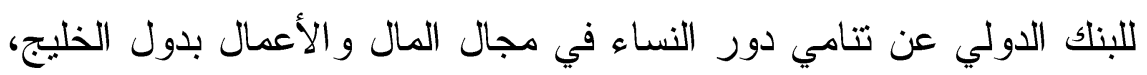
وذكرت البيانات أن § (\% من المؤسسات العربية تملكها سيدات أعمال(باء).

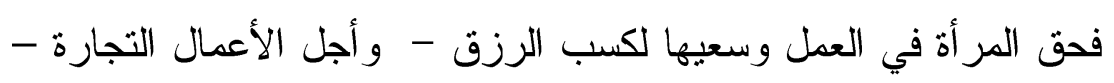
حق مشروع لها مثلها مثل الرجال (") الرئ

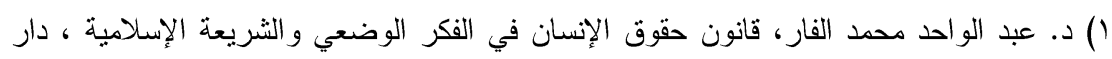

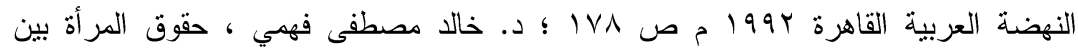

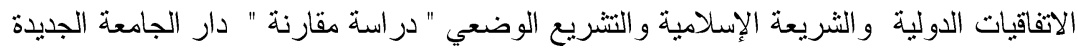

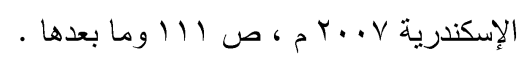

/( $r / /$ saudiwomen.wordpress.com/stats

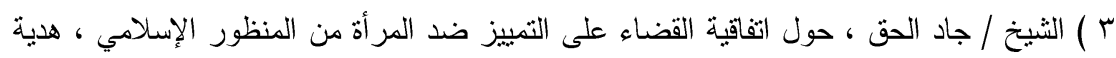

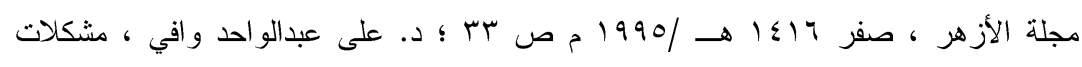

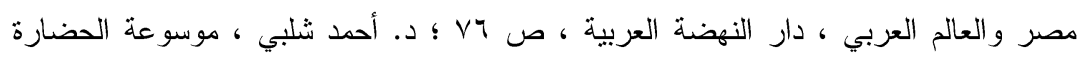

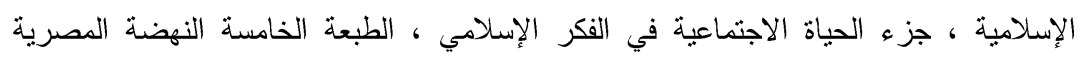

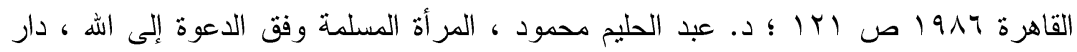

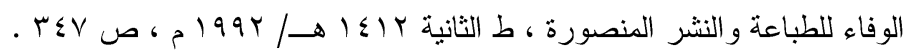




\section{أحقية المرأة في ممارسة التجارة في النظم الداخلية}

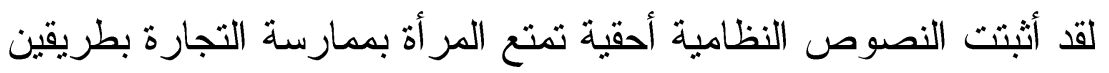

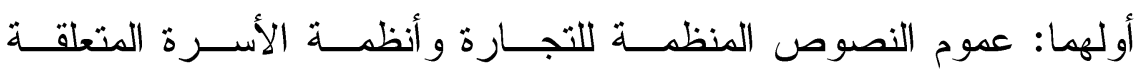
بتقرير الأهلية ـ و الآخر : النصوص النظامية الخاصة بتثرير حق ممارســة

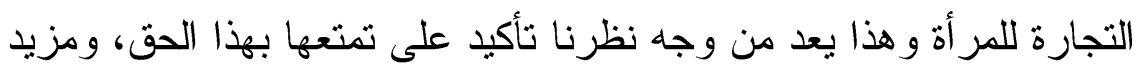

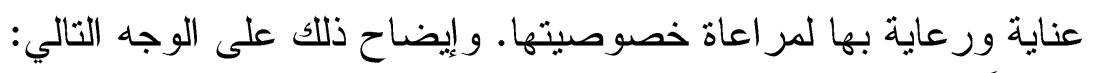

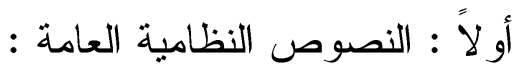

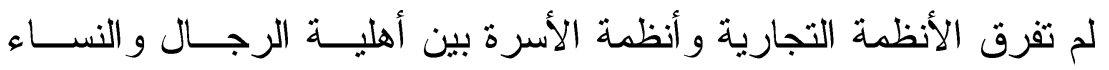
متزوجات أو غير متزوجات فمتى بلغت السن المقررة للأهلية غير مصابة بعارض من عوارض الأهلية فإنها تكتسب صفة التاجر متى تو افرت شروط

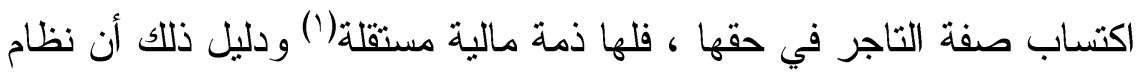

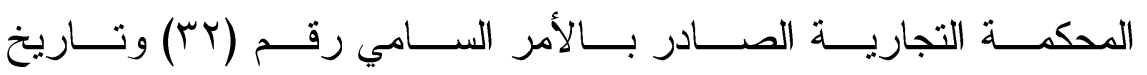

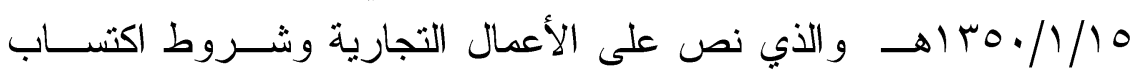

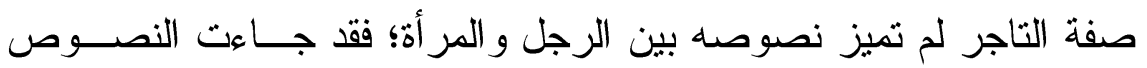

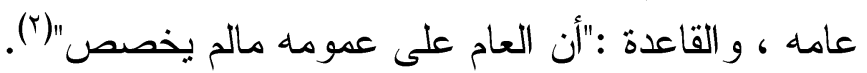

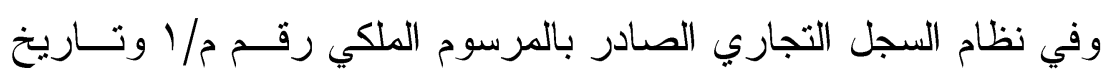

1) الذمة لغة : العهد ؛ لأن نقضه يوجب الذم . و اصطلاحاً : صفة يصير الإنسان بها أهلاً للالتز ام ؛

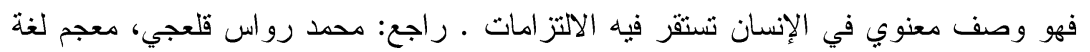

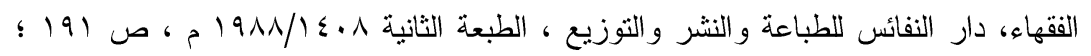

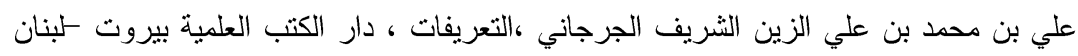

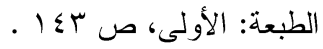

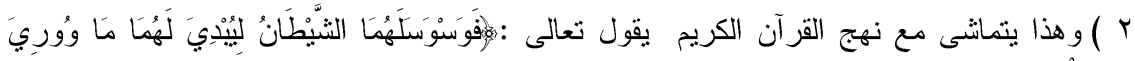

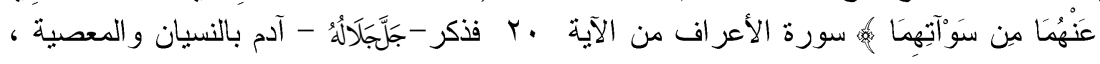

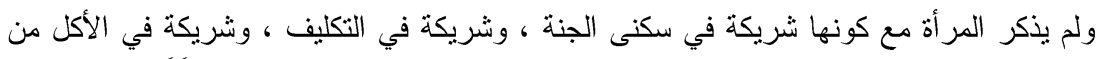

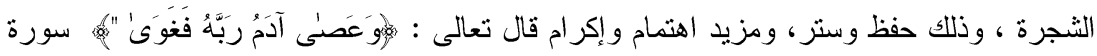




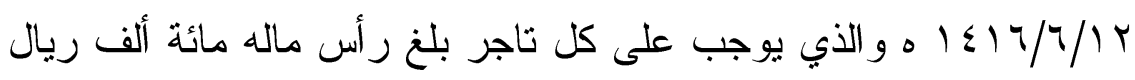

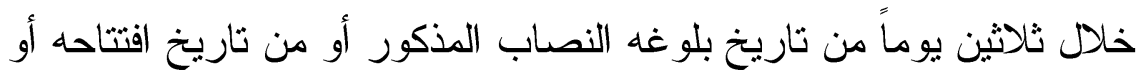

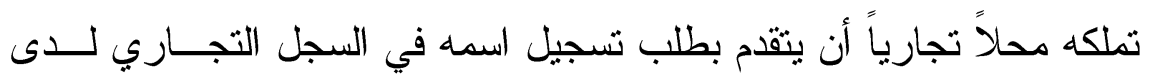

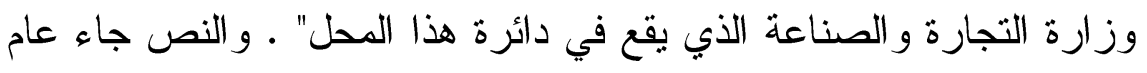
لم يفرق بين الرجال و النساء. كما أن القو اعد العامة تقتضي تمتع المر أة بالحقوق التي ينعم بهاء الرجال

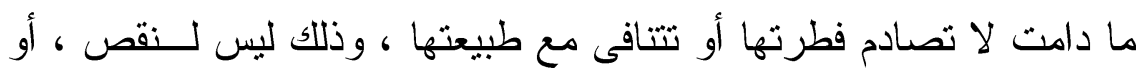

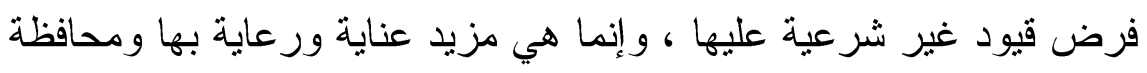

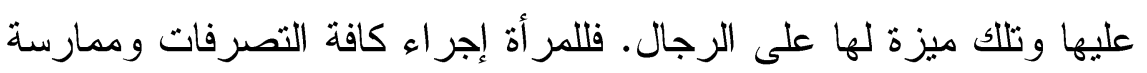

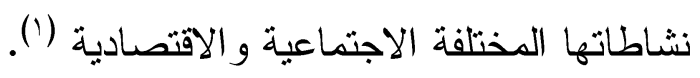
ثانياً : النصوص النظامية الخاصة : لقد جاء النظام السعودي بنصوص و اضحة الدلالة على جواز ممارســة

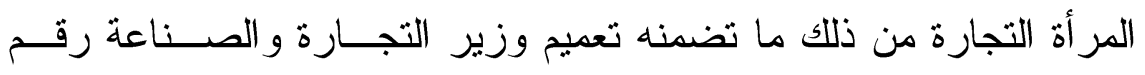

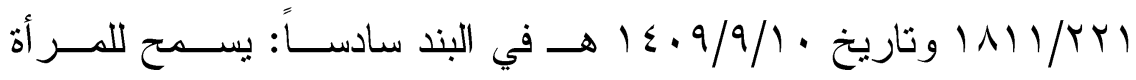

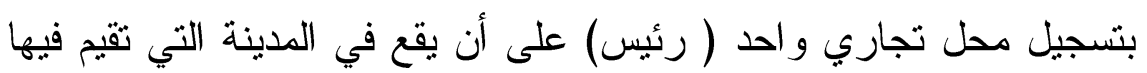

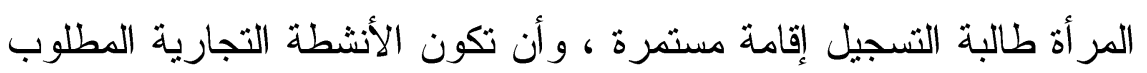

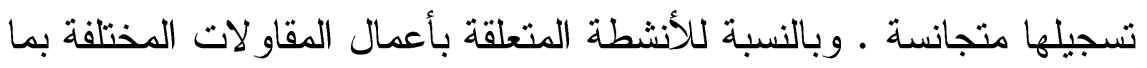

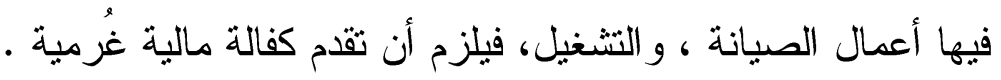

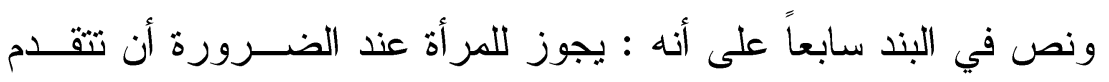
بطلب لتسجيل فرع و احد فقط في المدينة التي تقيم فيها المر أة طالبة التنجيل

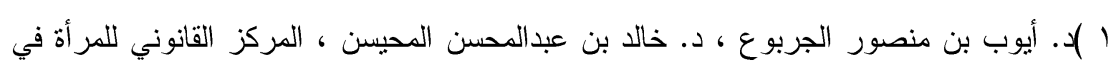

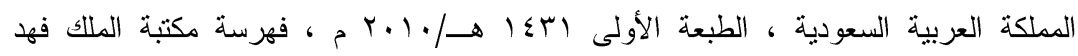

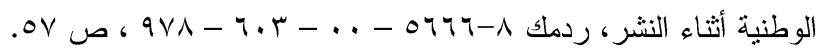


، على أن يعرض هذا الطلب على معالى الوزير" وزير التجارة و الصناعة "

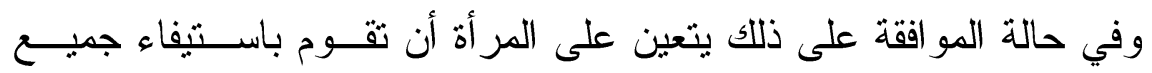
المستندات النظامية اللازمة للقيد في السجل التجاري .

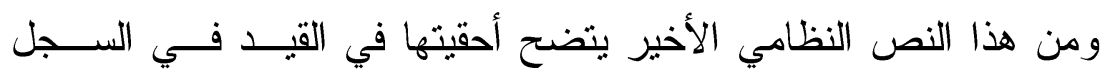

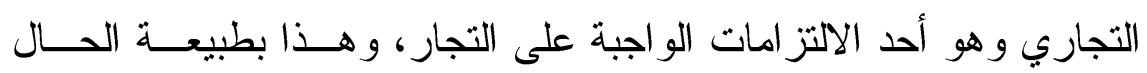
بستلزم سبق تمتعها بأحقيتها في ممارسة التجارة .

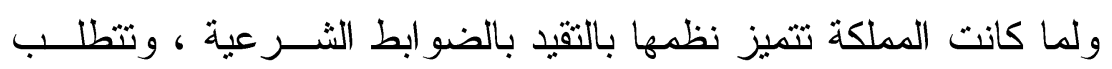
ضرورة عدم اختلاط النساء بالرجال؛ فقد ثقرر وجــود وحــدات نســائية

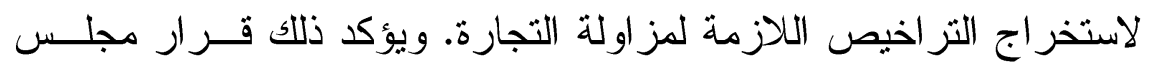

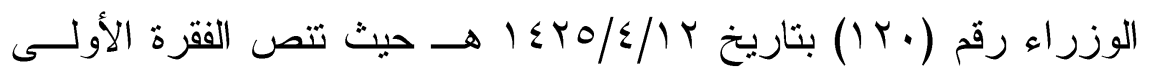

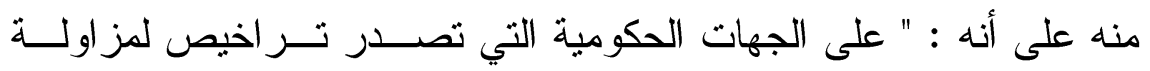
الأنشطة الاقتصادية - كل جهة في مجال اختصاصها - اســتقبال طلبــات النساء لاستخر اج التزاخيص اللازمة لمزاولة تلك الأنشطة التي تمنحها هذه

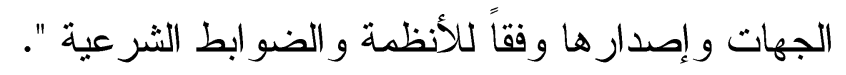
ونص في المادة الثانية منه على أنه : على جميع الجهات الحكومية التي

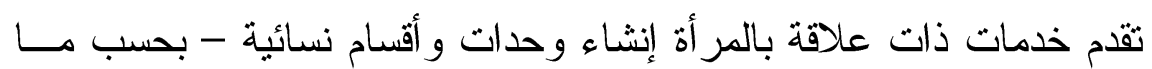
تقتيه حاجة العمل فيها وطبيعته - خلال مدة لا تزيد على سنة من تاريخ

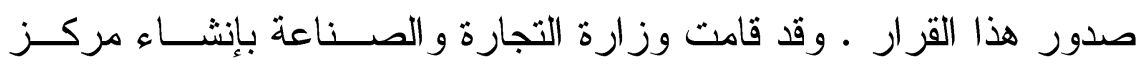
لخدمة السيدات يهدف إلى تقديم الخدمة مباشرة إلى المر أة دون الحاجة إلى لى

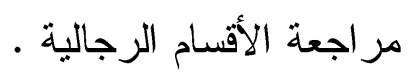
ويتضح من ذلك أن هذه الإجر اءات تهدف إلى تسهيل تمكين المر أة مـنـ

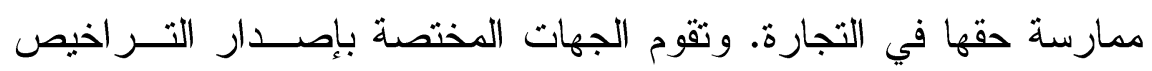




\section{مجلة كلية الدراسات الإسلامية والعربية بنات_- دمنهور العدد الثاني - المجلد السابع V|.rم}

للمر أة لمزاولة العمل التجاري ، وتم فتح مجالات جديدة لهن فــي المهـن

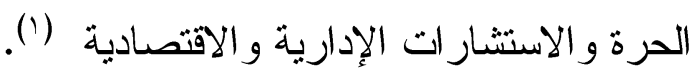

كما أنه يوجد لدى الهيئة العامة للاستثمار مركز خدمة المستثمر ات تعمل بــهـ كفاءات نسائية بهدف دعم القطاع الاستثماري النسائي • وكذلك تقــدم الغــرف

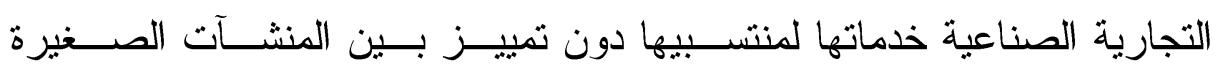

أو الكبيرة (r)

و هذه النصوص النظامية تؤسس لمبادئ مهمة وهي:

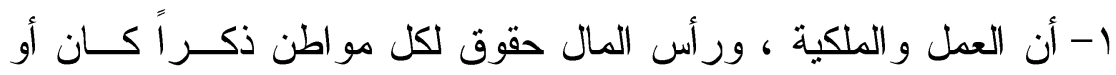

أنثى.

r - أن المملكة تسن من الأنظمة التي تجعل الحصول على العمل ميسـراً وفي ذات الوقت توفر الحماية للعمال و أصحاب العمل ـ ومن ذلك سن التن نظام بجو از قيادة السيار ات للمر أة ، و إنشاء جمعيات نسائية كتمكين . ب-أن كتاب الله تعالى وسنة رسوله صلى الله عليه وسلم همـــا الحاكمـــان

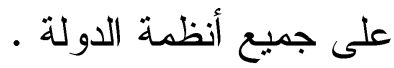
ء-أن جميع النصوص النظامية تتطبق على جميع المو اطنين رجالاً ونساء

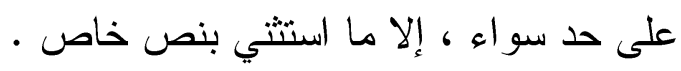
وعلى ذلك فللمر أة أن تمارس التجارة كشخص طبيعي أو تؤسس شـــركة

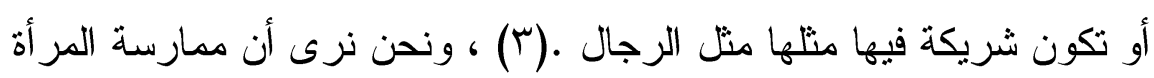

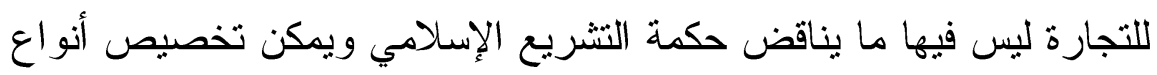
من التجار ات تقصر عليهن ومن ذلك محلات الأغر اض النسوية على كافــة

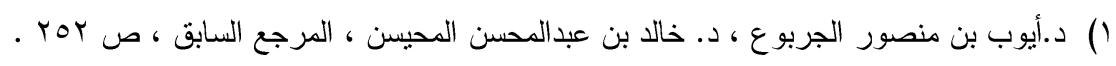

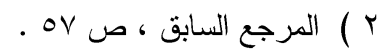

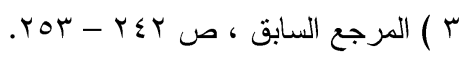




\section{" أحقية المرأة في ممارسة التجارةودورها في تحقيق رؤية المملكة •r+r ( دراسة مقارنة ...}

أنو اعها ، وشركات طبية لهن ومستشفيات خاصة للنساء و الأطفال تدار بهن وبو اسطهن ، ومطاعم ، ودور رعاية الأطفال وكل ما يمكن فيه العمل على الاقتصار على النساء دون حاجة فيها للرجال .

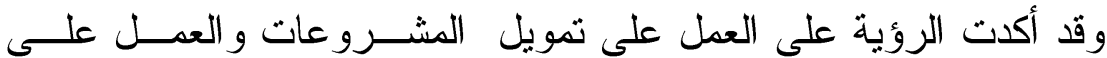

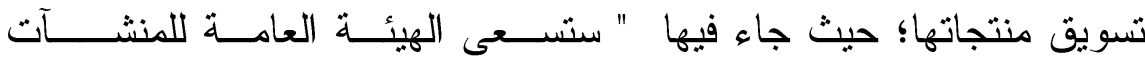

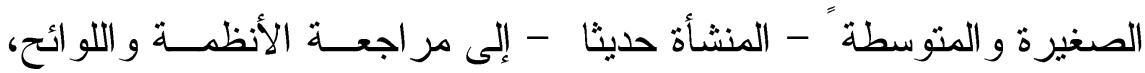

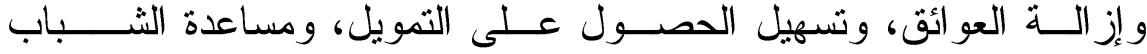

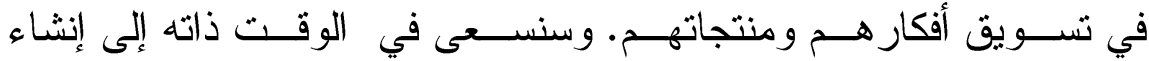

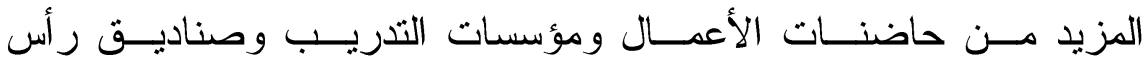
المــال الجـريء المتخصصـــة لمساعدة رواد الأعمـــال عــلـــى تطويـــر مهار اتهــم و ابتكار اتهــم، كما سنســاعد المنشــآت الوطنيــة الصغـــــرة

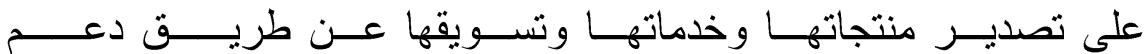
التشــــيق الإلكــتروني و التتســيق مــع الجهــات الدوليــة ذات العلاقة." الالتزامات التجارية للمرأة : الإن إذا مارست المرأة التجارة (') وجب عليها الالتزامات التجارية ، وهـيـي (1) وممارسة التجارة رهين بتوافر أهلية الأداء ، ومع ذلك يجوز للقاصرة ممارسة التجارة في حالات

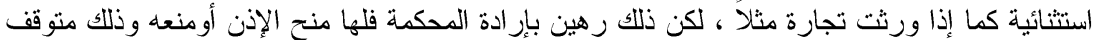

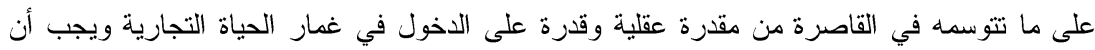

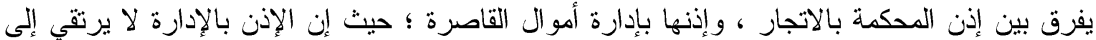

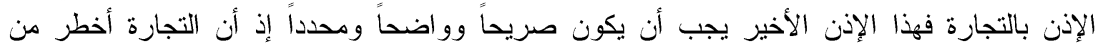

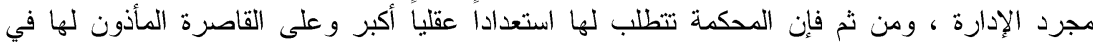

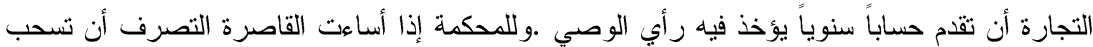

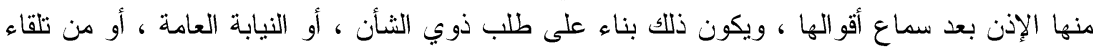

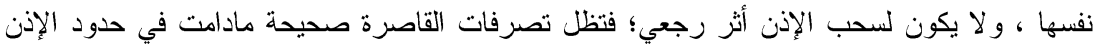

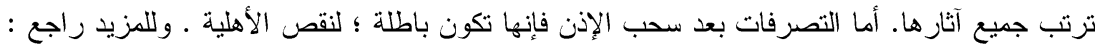

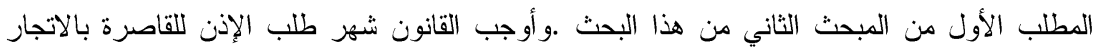
$=$ 


\section{مجلة كلية الدراسات الإسلامية والعربية بنات_-دمنهور العدد الثاني - المجلد السابع r.lrم}

القيد في السجل التجاري وقد سبق بيانه في البند السابق ، وكذلك الإمســاك

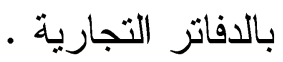

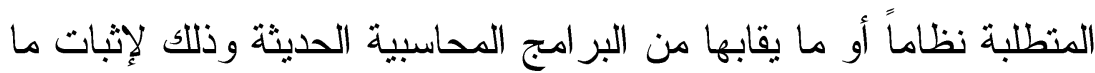

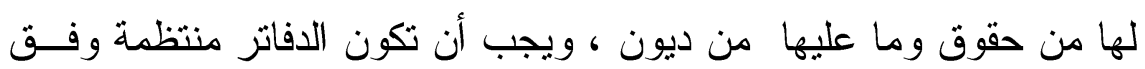

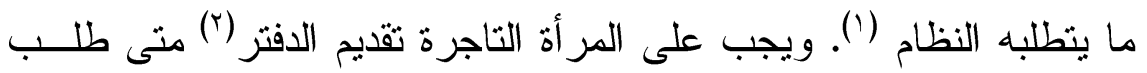

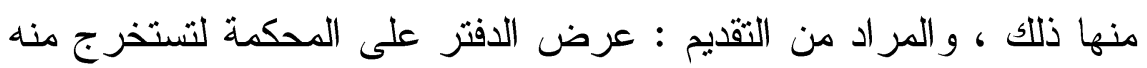

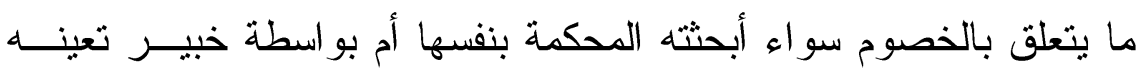

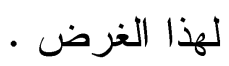

و لا يجوز في حالة التقديم تسليم الدفاتر لخصم التاجرة حتى يبحث فيهــا ويطلع على أسرار خصمه ؛ بل ينبغي حال اطلاع المحكمة أو الخبير على فلى لإنى الدفتز ضرورة حضور التاجرة أو من تتيبه لذلك، وينتهى الأمر كله متـى بلى

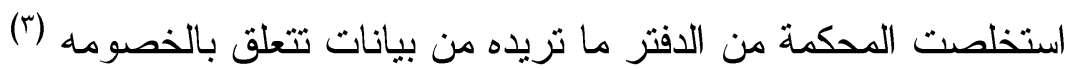

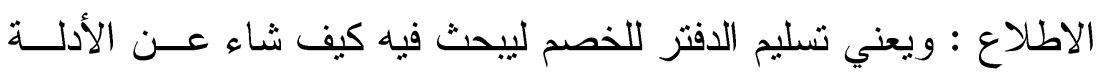

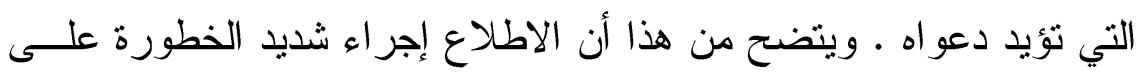

وطلب الإلغاء في سجل معد لذلك بقلم كتاب المحكمة ـ و وعلى قلم الكتاب التأنشير على هامش تسجيل

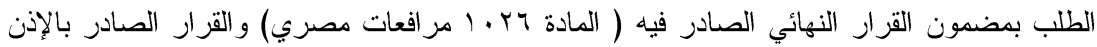

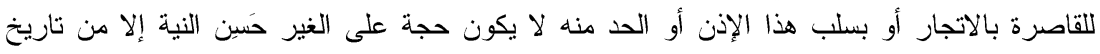

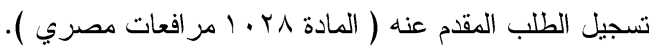

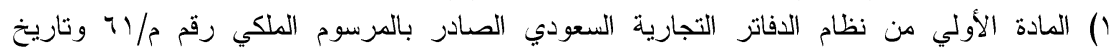

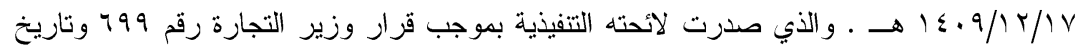

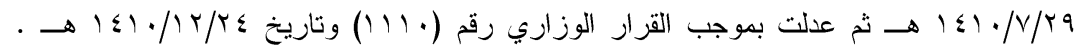

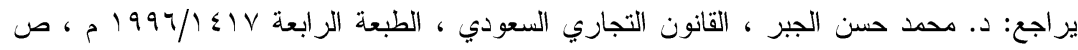

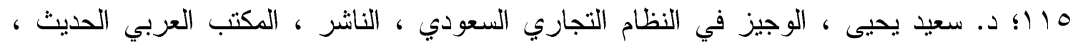

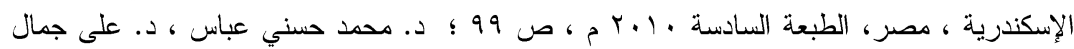

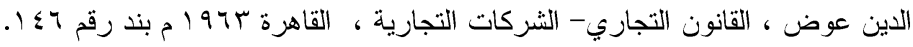

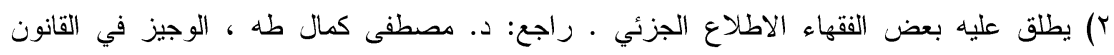

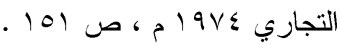

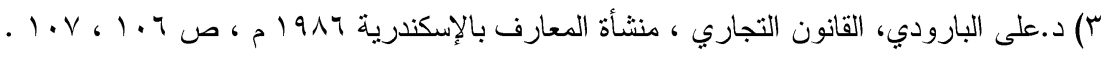




\section{أحقية المرأة في ممارسة التجارة ودورها في تحقيق رؤية المملكة •ب.r ( دراسة مقارنة ...}

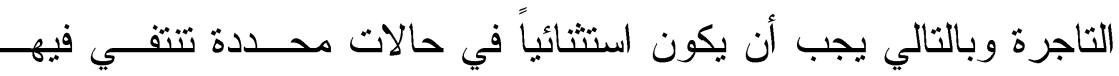

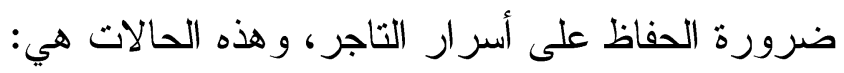

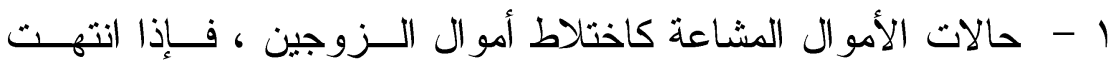

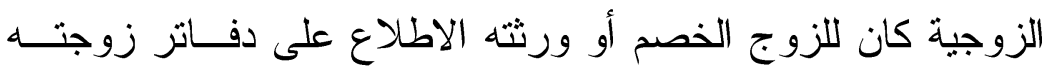

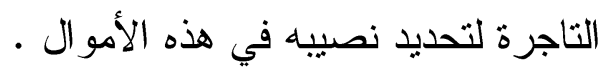

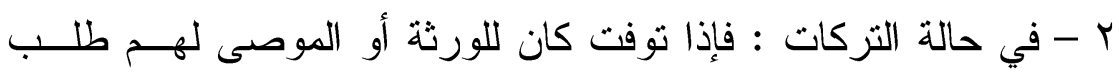

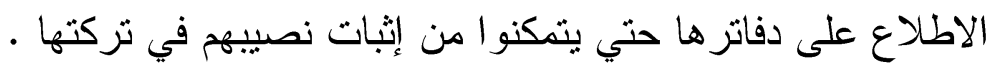
r - قسمة الثركات : فإذا انقضت الثركة ودخلت مرحلة التصفية كــان

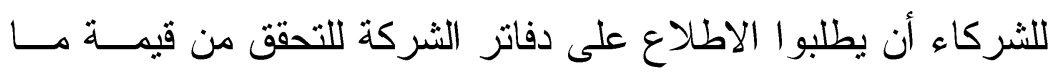
يحق لكل منهم من قسمة موجوداتها. ع - في حالة الإفلاس : لأمين التفليسة الاطلاع على دفاتر التاجرة المفلسة

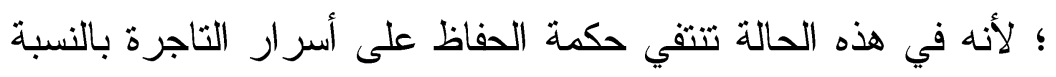

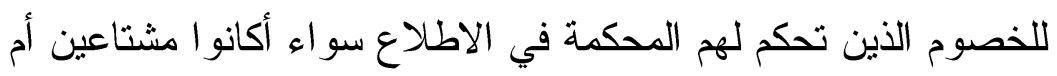
ورثة أم شركاء أما في حالة الإفلاس فقد انهارت التجارة بأسر ها ولم المان

$$
\text { يعد فيها سراً ('). }
$$

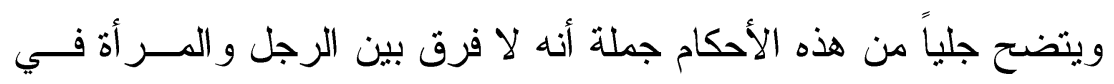

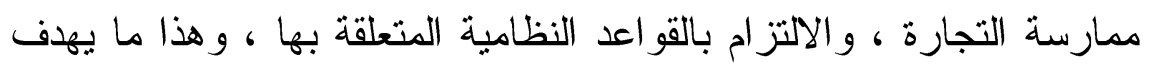

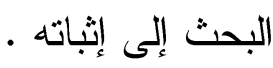




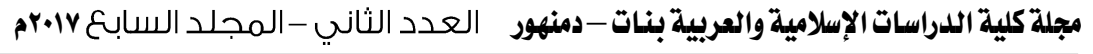

\section{المبحث الثاني}

\section{موقف الثريعة الإسلامية من ممارسة المرأة التجارة.}

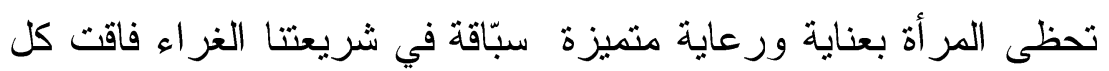

النظم وقد أعمل الفقهاء جهدهم في تفصيل حقوق المر أة عامة ، وحقها فـــي فئسي

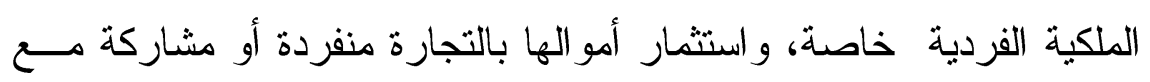

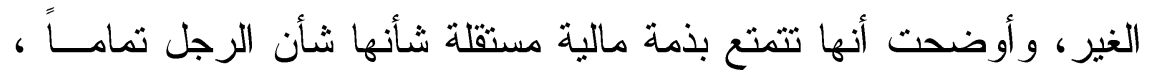
ويظل لها هذا الحق في الاستقلال المالي حتى بعد زواجها ، وليس للــزورج منعها من ممارسة التجارة، وبيان ذلك في المطلبين التاليين:

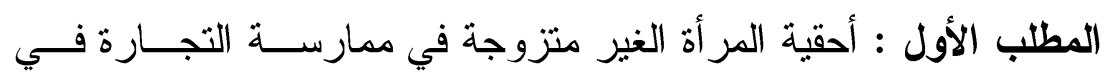
الثريعة الإسلامية.

المطلب الثاني: أحقية المر أة المتزوجة في ممارسة تجارة منفـرده عــن زوجها في الثريعة الإسلامية . 


\section{المطاب الأول}

\section{أحقية المرأة الغير متزوجة في ممارسة التجارة في الثريعة الإسلامية}

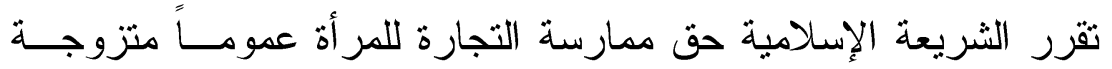
كانت أم غير متزوجة، وقد أوضحت نصوص القر آن الكريم و السنة النبوية ذللك :

\section{أولا: النصوص القرآية :}

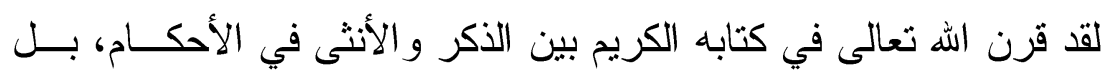
قرر المفسرون أن النصوص الواردة بصيغة المذكر تشمل الرجل والأنثى ،

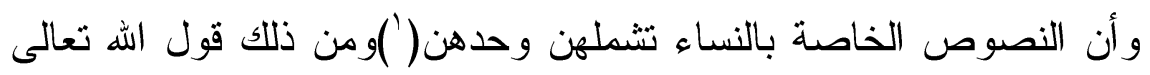

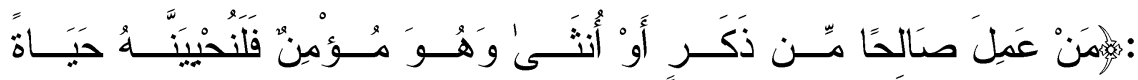

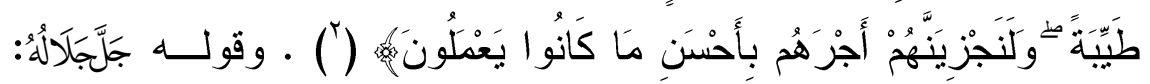

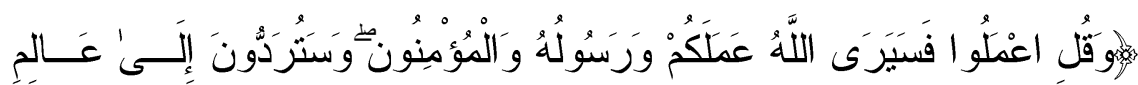

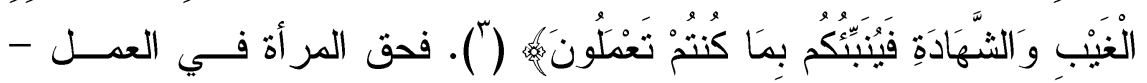

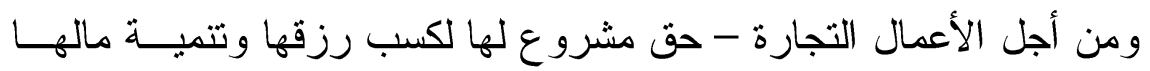

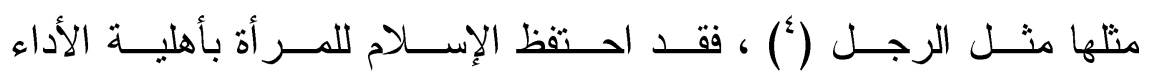

() أو بعد هذه العناية الربانية من قول في رعاية المرأة وتمتعها بالحقوق بأن يفرد لها أحكاما خاصة

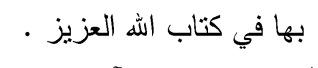

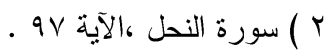

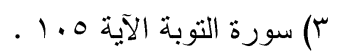
؛ ) الثيخ / جاد الحق ، حول اتفاقية القضاء على التمبيز ضد المرأة من المنظور الإسلامي ، هدية

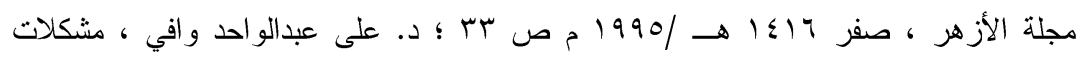

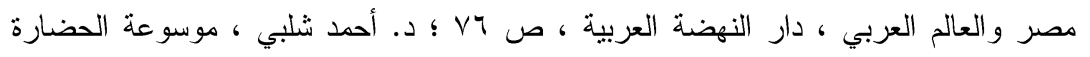

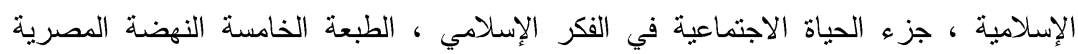

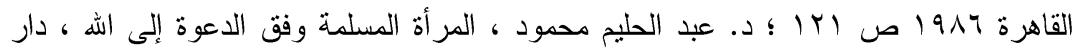

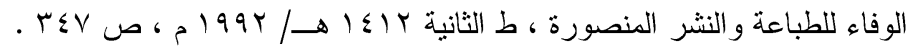


و الوجوب(')مثل الرجل و لا تفرقة ولا تمييز بسبب الدين أو الجنس أو اللون

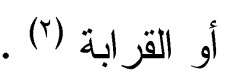

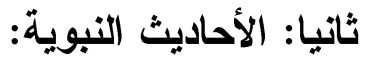

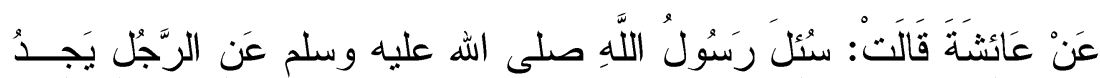

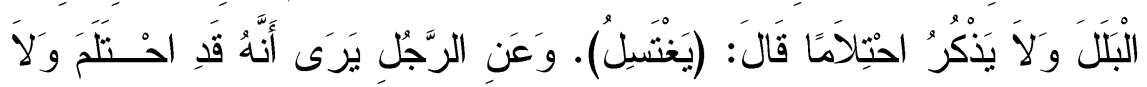

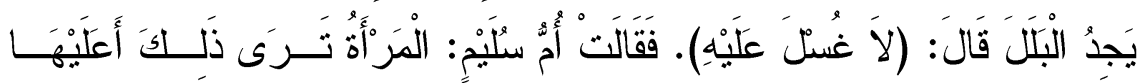

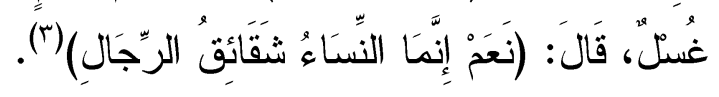

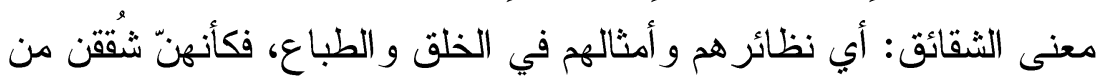

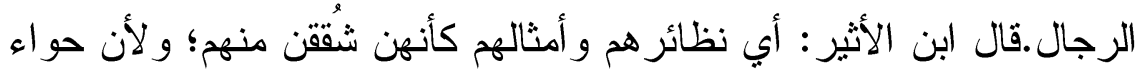

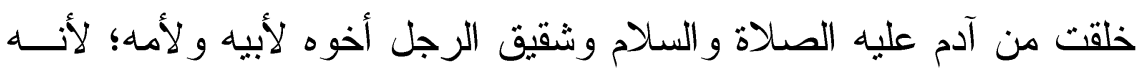

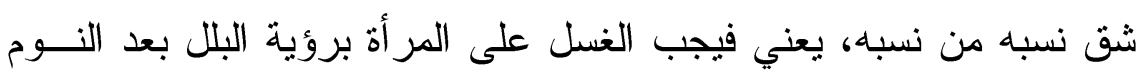

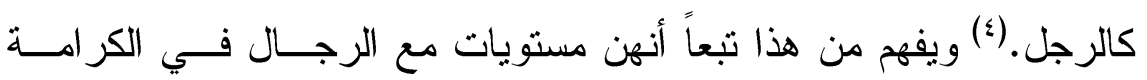

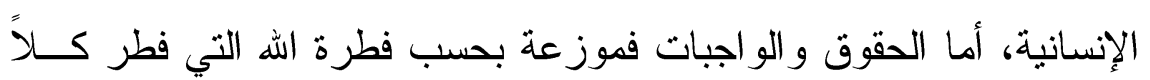

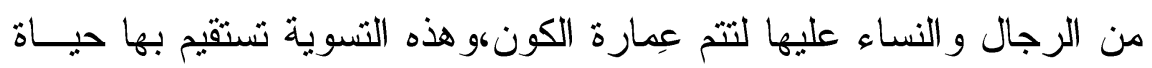
الناس ويستقر المجتمع وينعم باستثمار مالها (0) . وما رواه مسلم في صحيحه عن قيلة أم بني أتمار قالت: أتيت رسول الله

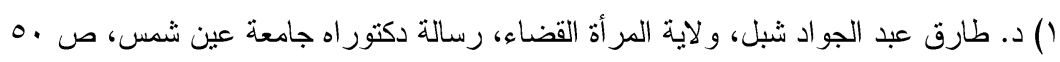

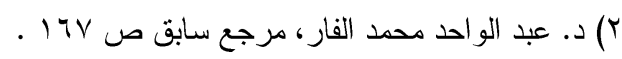

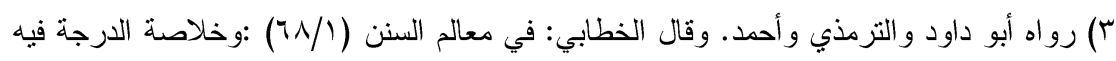

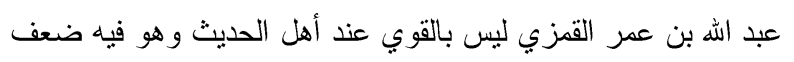

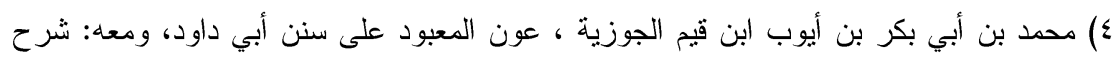

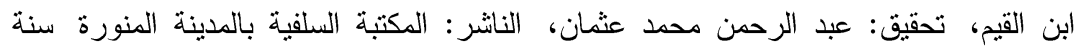

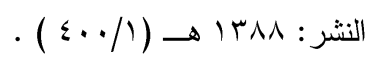

0) د. أنس قاسم جعفر،الحقوق السياسية للمرأة في الإسلام والتثريع المعاصر، دار النهضة

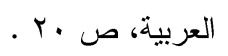


صلى الله عليه وسلم في بعض عمرة عند المروة فقلت : يارسول الله إنــي

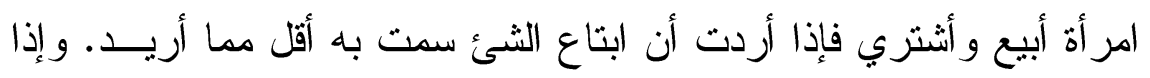
أردت أن أبيع الثئ سمت به أكثر من الذي أريد، ثم وضعت حتى أبلغ الذي لثي

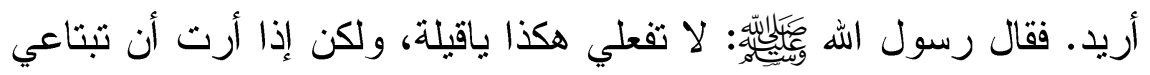
شيئًا فأعطي به الذي تريدين أن تأخذيه به أعطيث أو منعت ، و إذا أردت أن

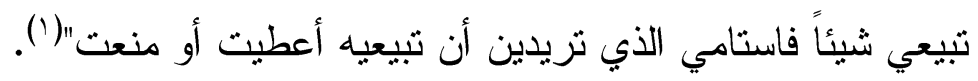

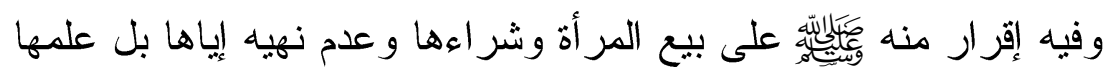
أصول البيع و الثر اء. وهذا من أقوى الأدلة على أحقية المر أة في ممارســة

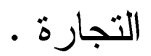

وقد قرر جمهور الفقهاء من الحنفية و الثافعية وعطاء وسفيان الثـوري

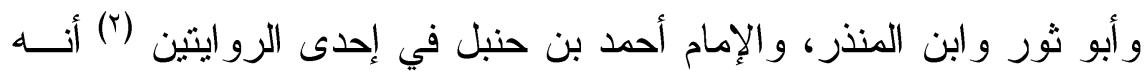
تثبت للمر أة أهلية الوجوب و أهلية الأداء كما هي ثابتة للرجل فلها ذمة مالية

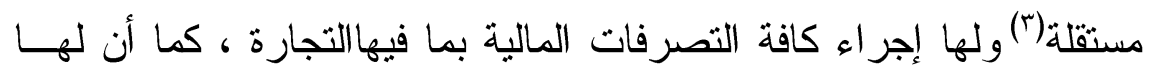

( ) أبو عبد الله محمد بن سعد بن منيع الهاثثمي بالولاء، البصري، البغدادي المعروف بابن سعد،

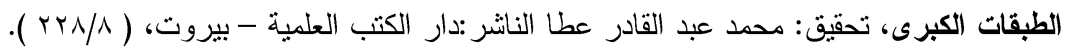

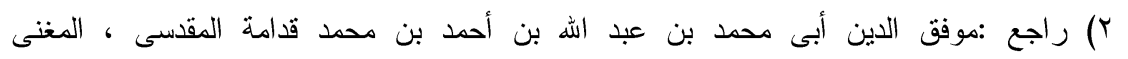

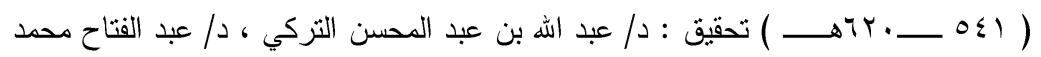

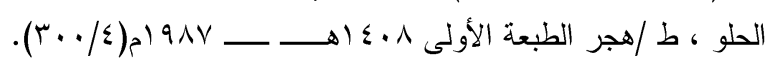

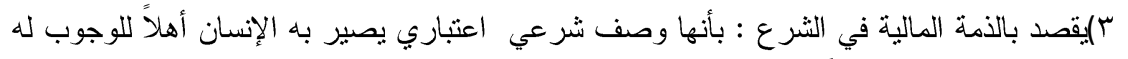

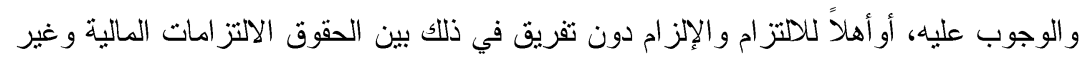

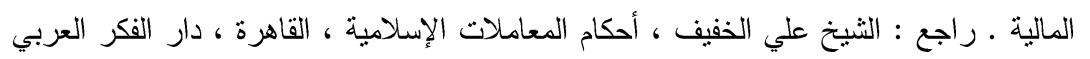

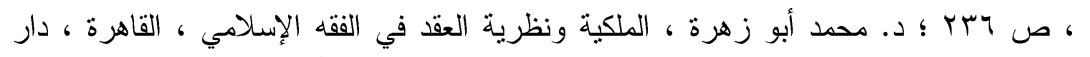

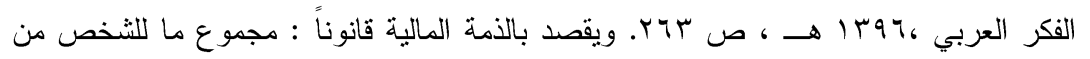

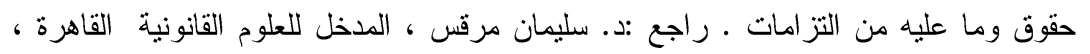


إنثاء الالتزامات كعقود البيع و المقاولة ، فقد اتفق الفقهاء على إعطاء مالها

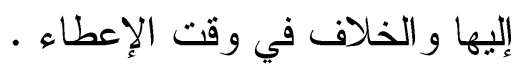
و الجمهور يرون أن المر أة إذا بلغت رشيدة يدفع لها مالهــا قياسـاً

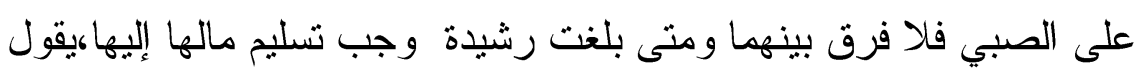

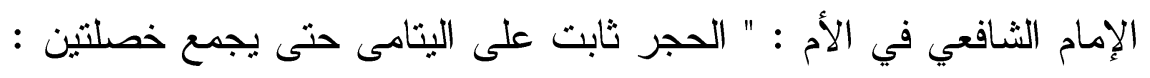

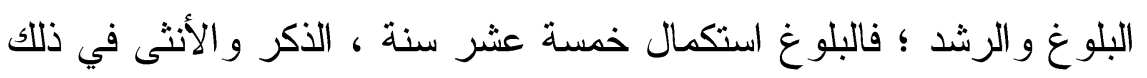

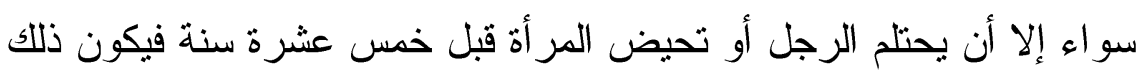

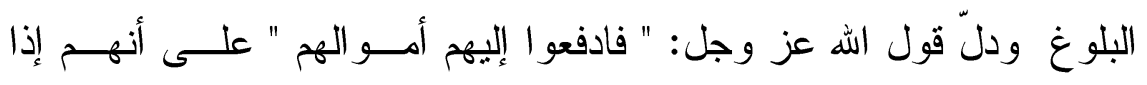

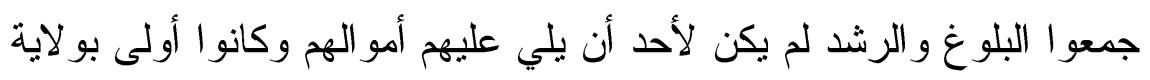

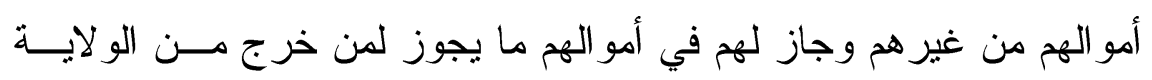

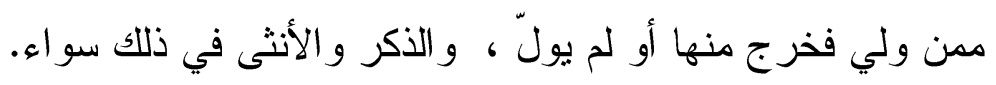

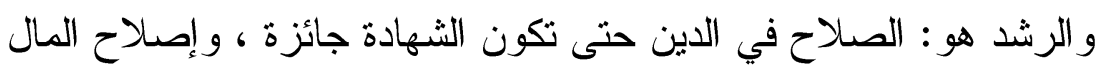

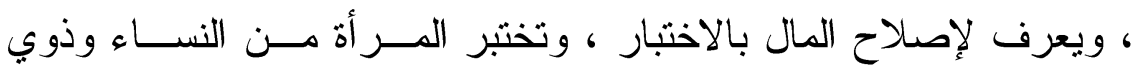

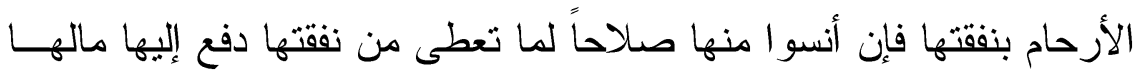

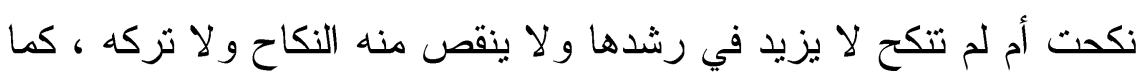

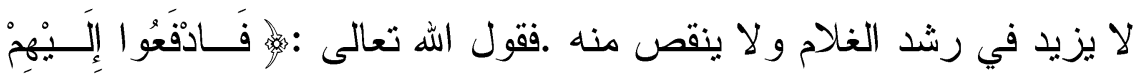

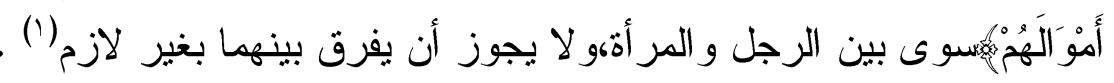

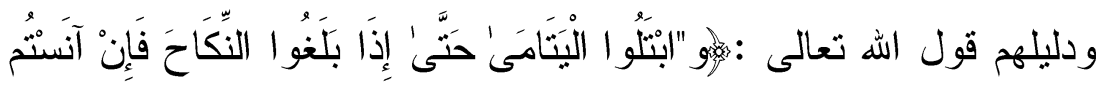

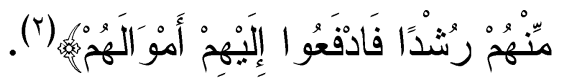

وجه الدلالة :أمر المولى عز وجل بدفع المال المستحق للأكر والأنثى إذا

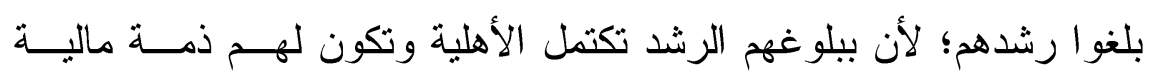

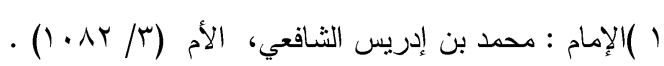

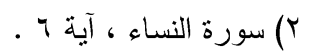




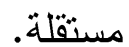

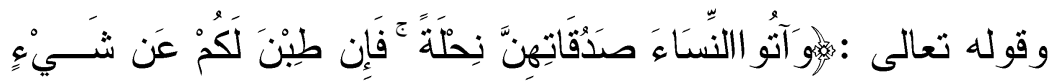

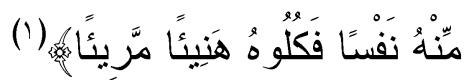

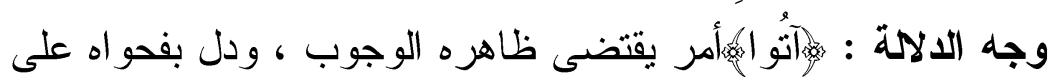

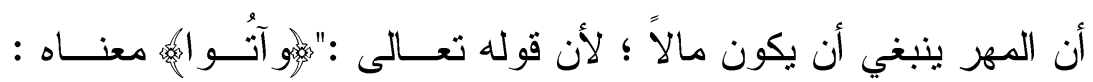

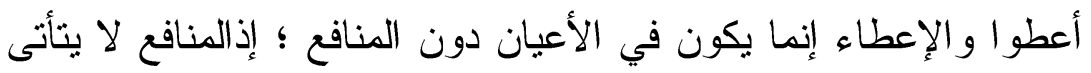

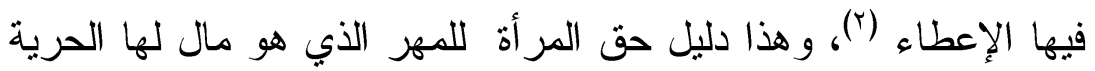
في التصرف به بشر اء وغيره من المعاملات المالية .

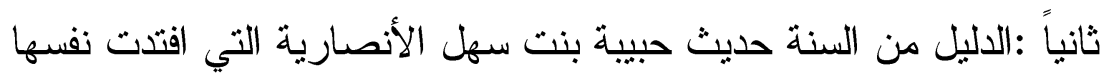

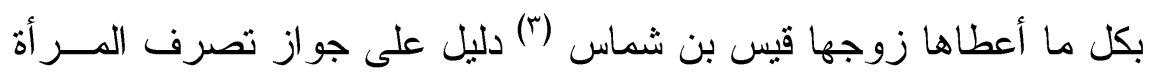

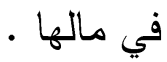

الرأي الثاني: ما نقل عن الإمام أحمد : أنه لا يدفع إلى الجارية مالها بعد

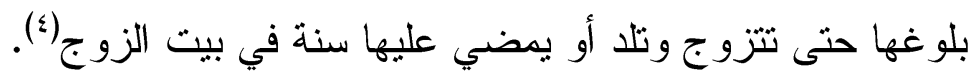

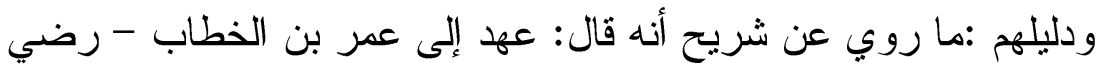

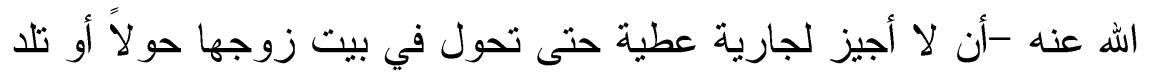
ولداً (0)

الرأي الثالث : مذهب المالكية ورواية عن أحمد : لا يدفع إليها مالها حتى

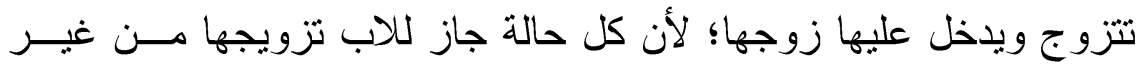

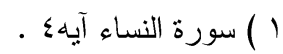

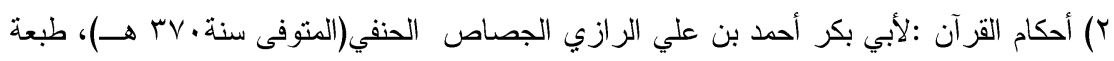

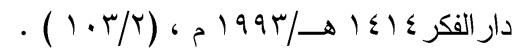

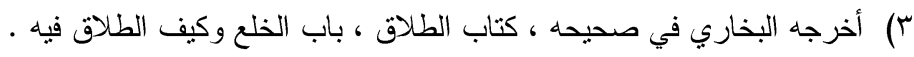

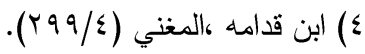

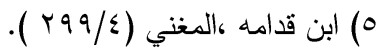


إذنها لم ينفك عنها الحجر كالصغيرة (1).

وقد ناقش الجمهور أدلة المانعين إعطاء مالها إليها من وجهين:

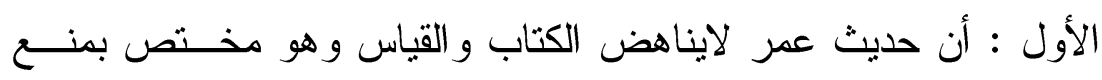

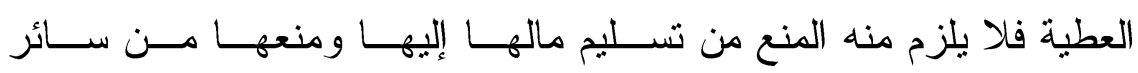

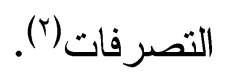

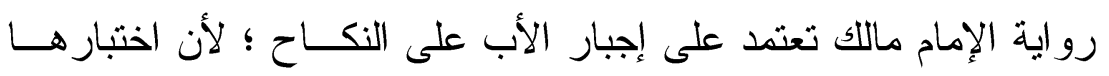

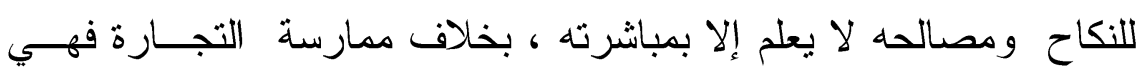

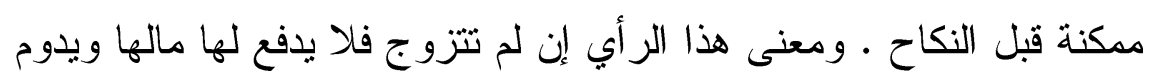
الحجر عليها ، وهذا غير متصور بدلالة أن القاضي عياض قال : عندي أن يدفع إليها مالها إذا عنست وبرزت للارجال يعني كبرت (r).

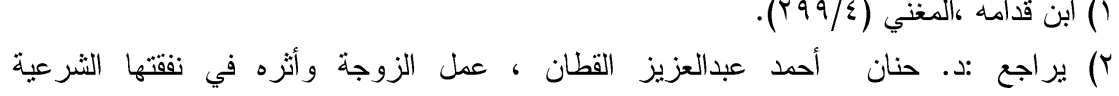

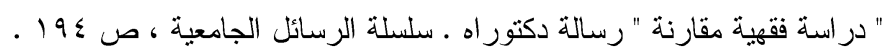

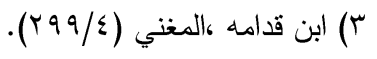


المطلب الثاني

\section{أحقية المرأة المتزوجة في ممارسة تجارة منفردة عن زوجها في الشريعة الإسلامية}

لقد ثقرر فيما سبق بيان أحقية المر أة في ممارسة التجارة شأنها شأن الرجل فحق التملك مقرر للمر أة (') وتبقى أموالها التي نمتلكها بعد زواجهــا

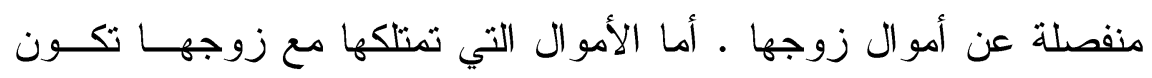

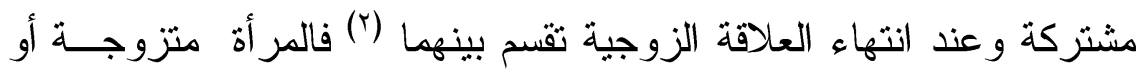

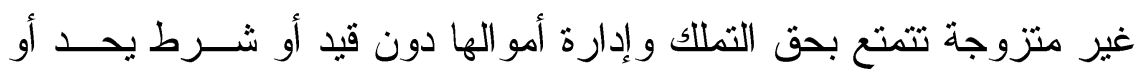

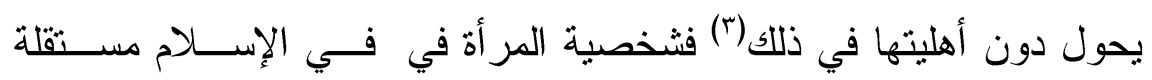
ومحترمة لا تذوب بعد الزو اج ولا قبله (ఓ). وقد اتفق جمهور الفقهاء() من الحنفية و الثافعية و المالكية و الحنابلة

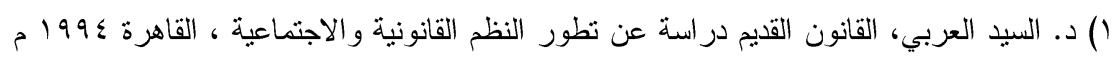

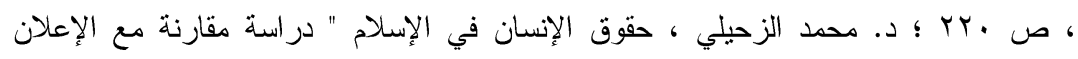

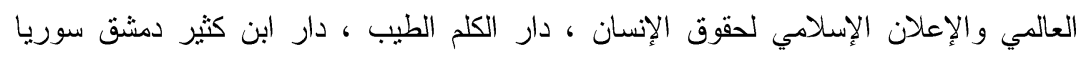

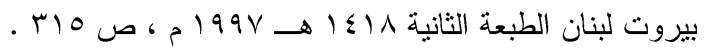

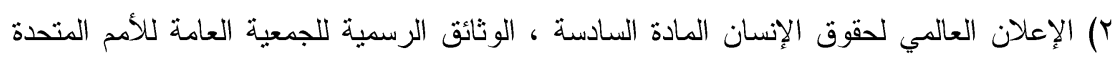

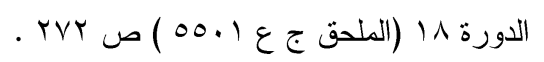

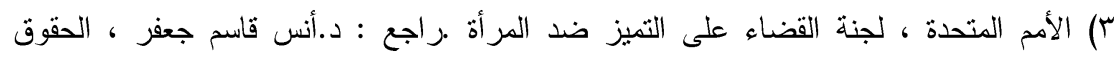

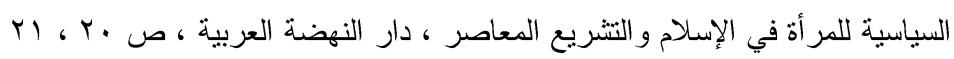

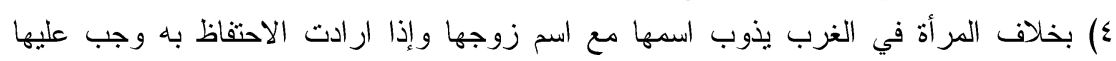

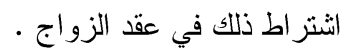

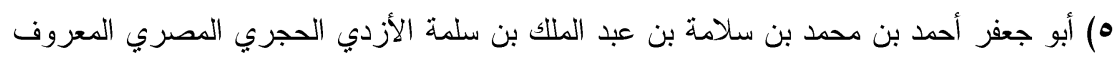

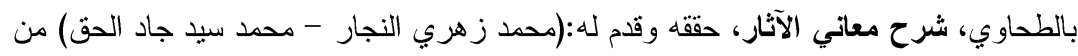

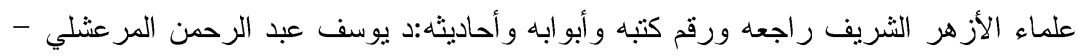

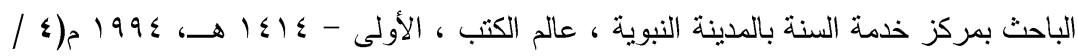

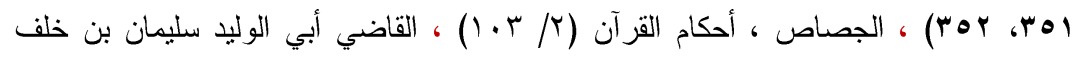

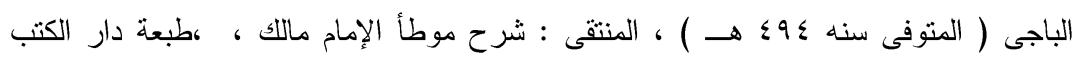
$=$ 
و الظاهرية على جواز تصرف الزوجة فى مالها بالبيع و الثراء بدون إذن

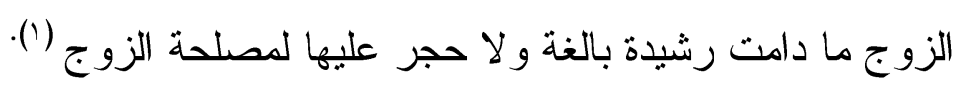

الأدلة :

استذل الجمهور على جواز تصرف الزوجة فى مالها بالبيع و الشر اء " "لدهاء التجارة " بدون إذن الزوج بالكتاب و السنة و المعقول:

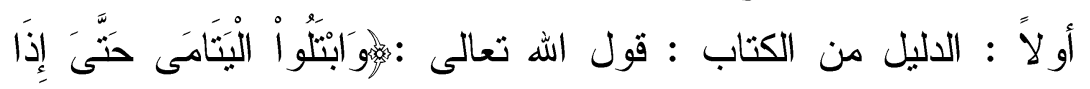

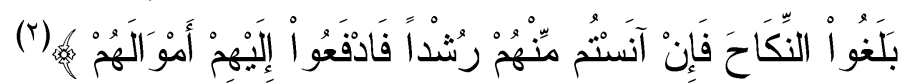
وجه الالالة : أمر الله عزوجل بدفع الأموال ؛ لأنه بلغ وأونس

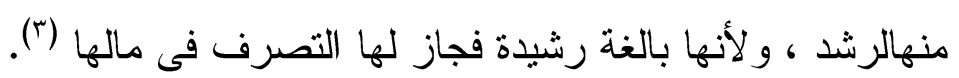

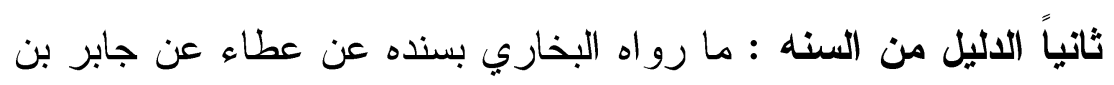

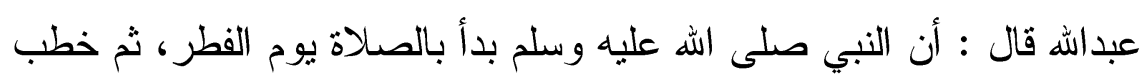

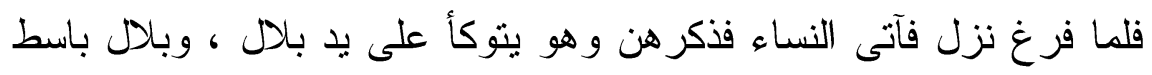

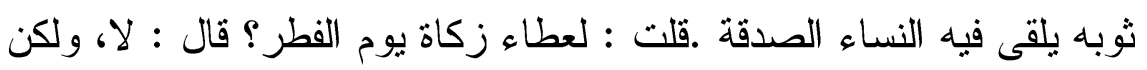
صدقه (ఓ) موبه

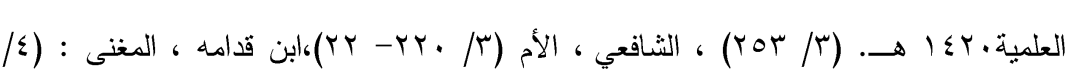

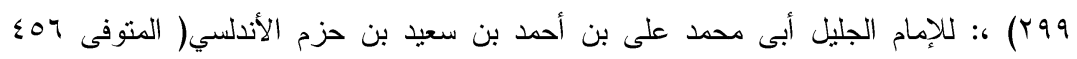

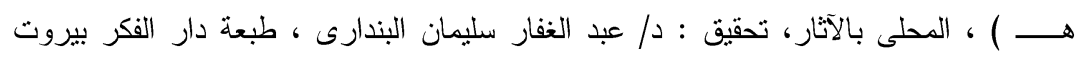

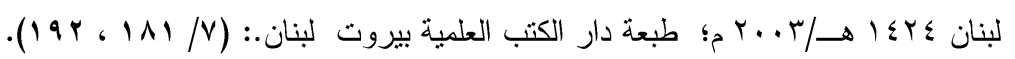

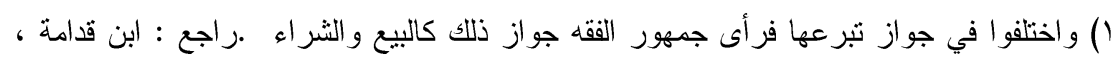

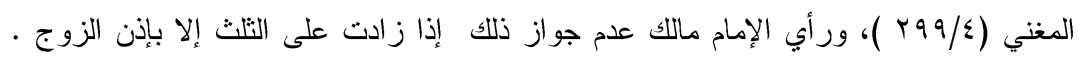

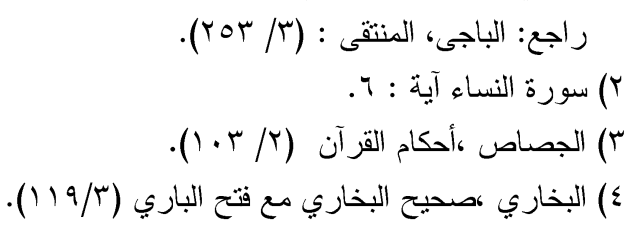




\section{· أحقية المرأة في ممارسة التجارةودورها في تحقيق رؤية المملكة •r+r ( دراسة مقارنة ...}

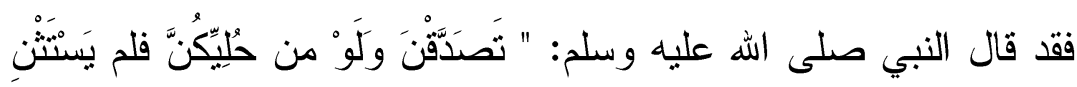

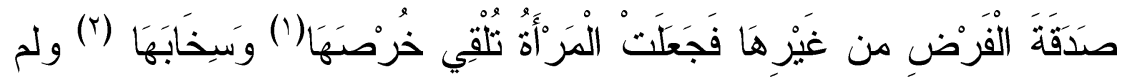

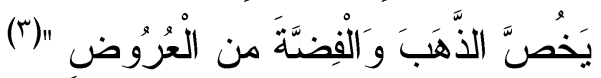

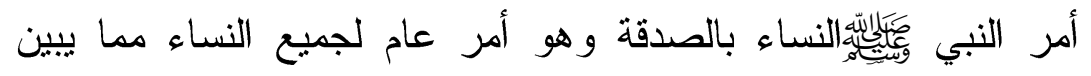

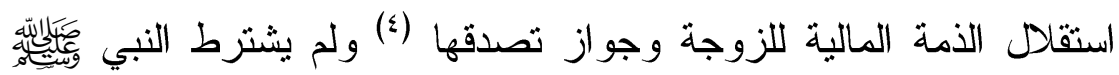

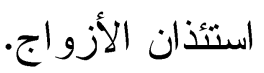
أن الصحابيات تصدقن فقبل رسول الله صدقتهن ولم بسأل ولم بيتفصل ، و آتته ر ائطة امر أة عبد الله بن مسعود و امر أة أخرى اسمها زينب فسألثه عن الصدقة هل يجزيهن أن يتصدقن على أزو اجهن و أيتام لهن فقال: نعم . وما رواه مسلم في صحيحه عن جابر بن عبداله قال: "طلقت خالتي

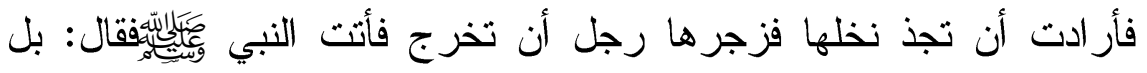
جذي نخلك لعلك أن تصدقي منه أو تفعلى خيراً" (0). وما رواه البخاري في صحيحه أن أسماء بنت أبي بكر قالت : " كنت

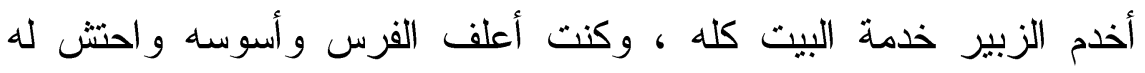

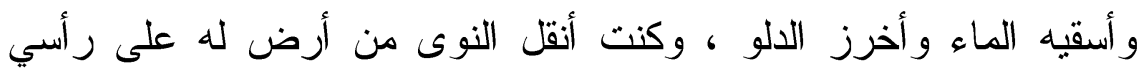

1) والخرص بضم المعجمة وسكون الراء بعدها مهملة : الحلقة التي تجعل في الأذن.

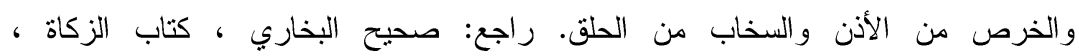

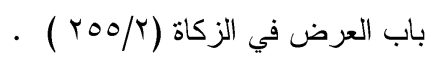

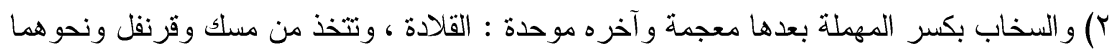

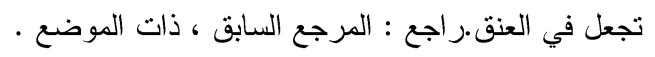

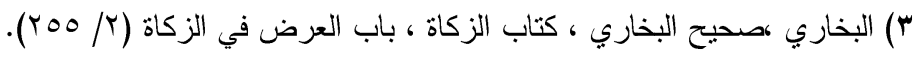

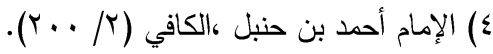

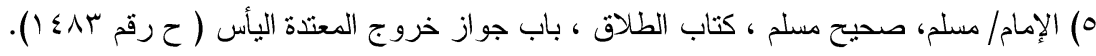


وهي في ثلثي فرسخ من المدينة (') . وقيل إنها كانت تفعل ذلك ليفرغ زوجها للجهاد. فللمرأة ذمة صالحة لكل الالتزامات ، ولها إرادة مستقلة تتشئ بها تصرفات يقر ها الشارع (؟).

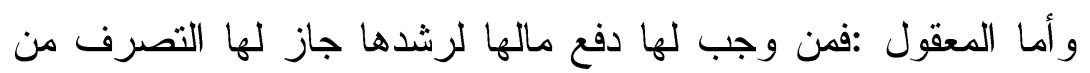

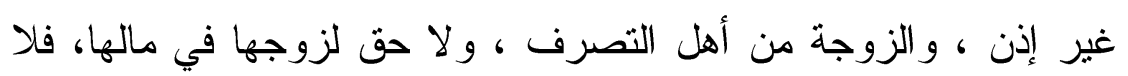
بملك الحجر عليها ("). ونو اردت النصوص عن عاء الفقهاء بجو از ممارسة المر أة المتزوجة التجارة

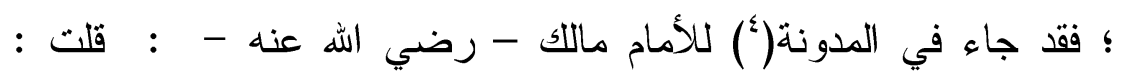

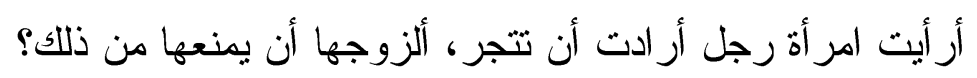

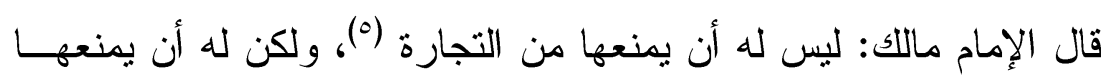

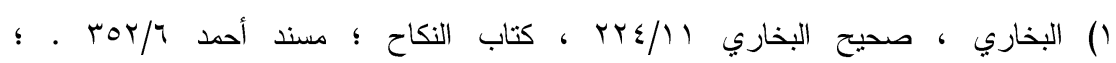

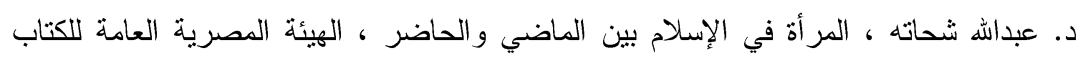

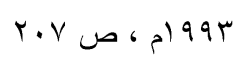

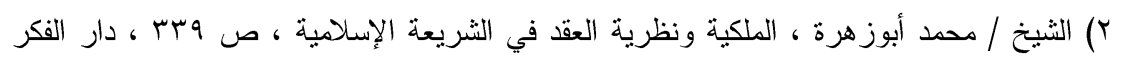

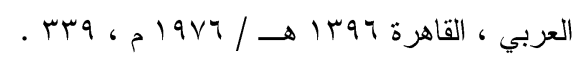

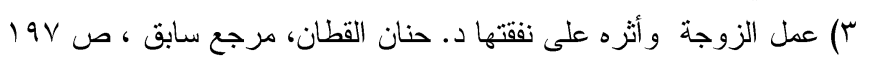

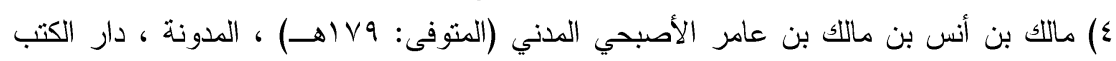

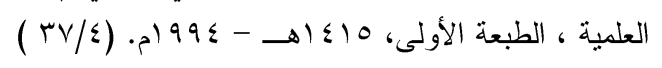

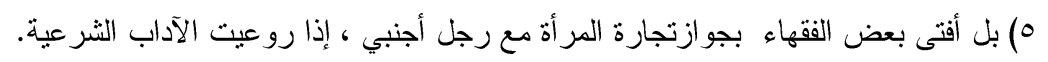

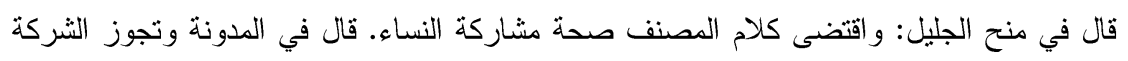

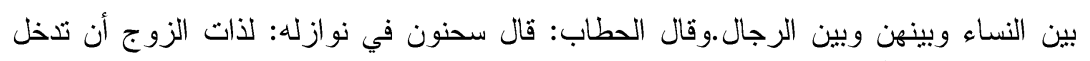

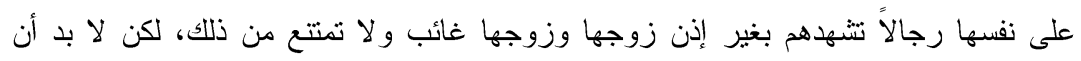

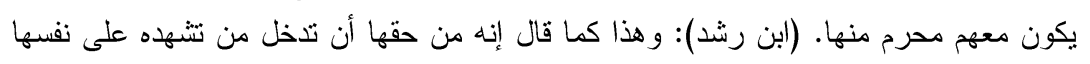

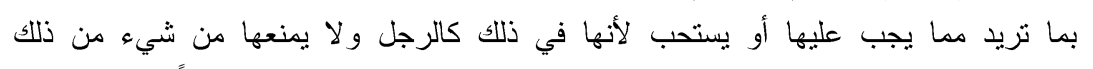

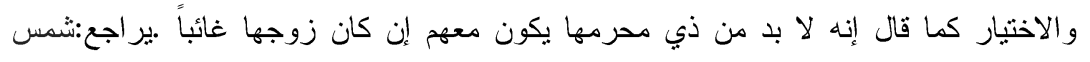

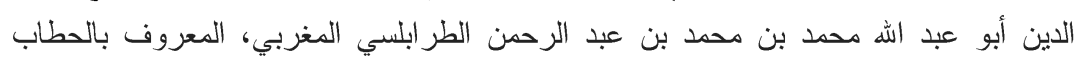

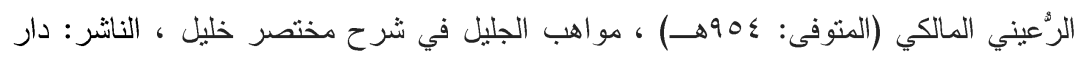

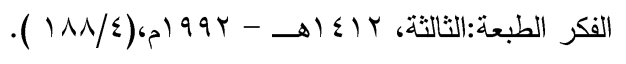




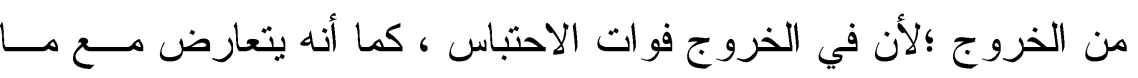

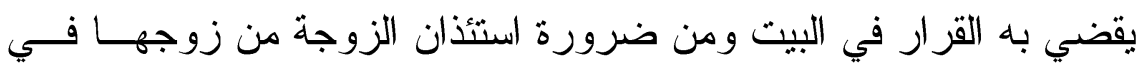

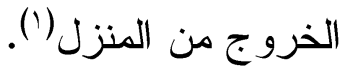
ولا ينبغي الغلو في فهم قرار المرأة في البيت؛ لأن ذلك يفوت

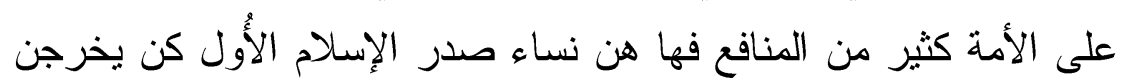

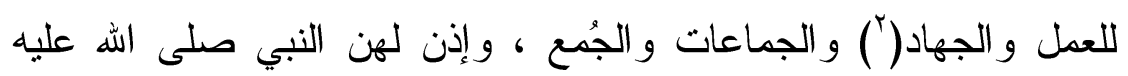

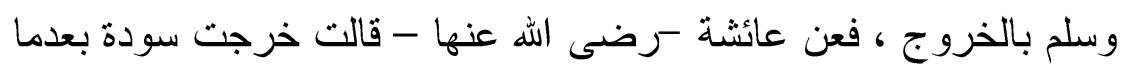
ضرب الحجاب لحاجتها وكانت امر أة جسيمة لا تخفى على من يعرفها

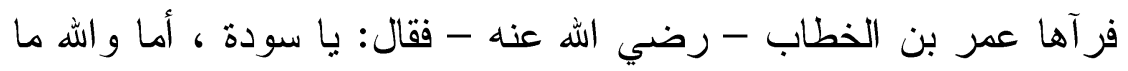

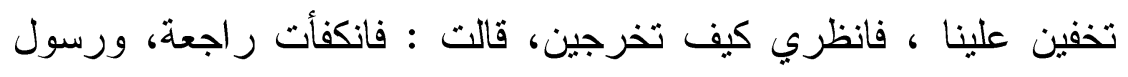
الله

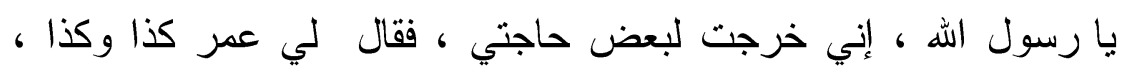

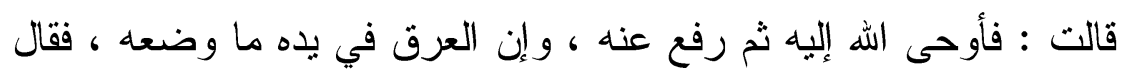

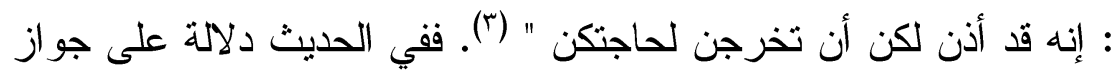

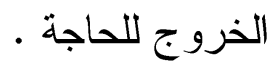

قال الإمام ابن حجر : قال ابن بطال: فقه هذا الحديث : أنه يجوز للنساء

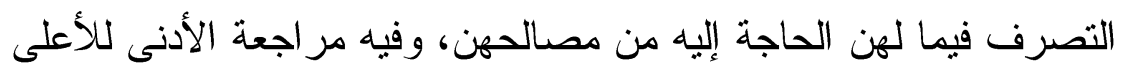

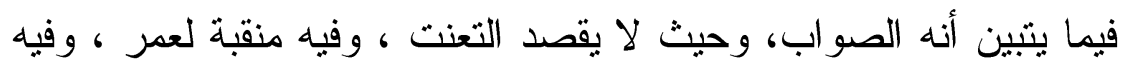

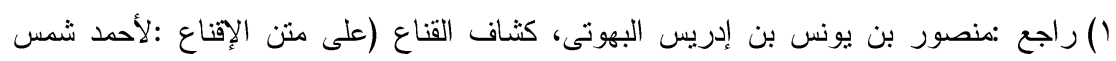

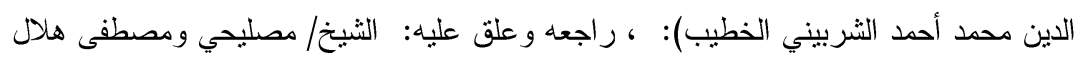

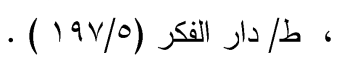

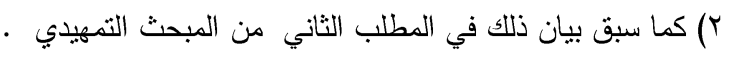

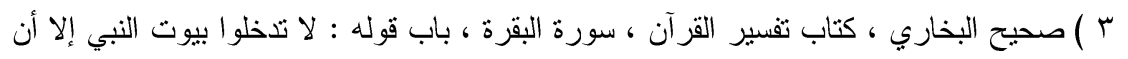

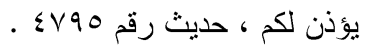


جواز كلام الرجال مع النساء في الطرق للضرورة ، وجواز الإغلاظ في

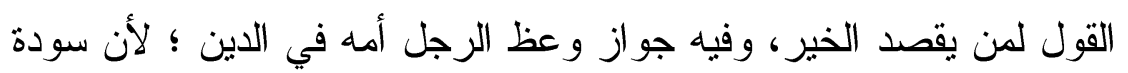

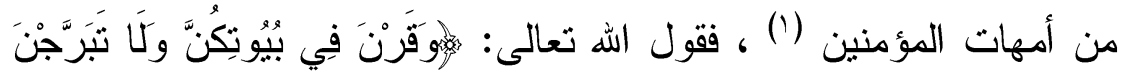

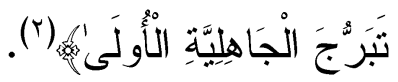
يدل على أن الأصل القرار في البيت ، لكن إلى إلى دعت الحاجة للخروج

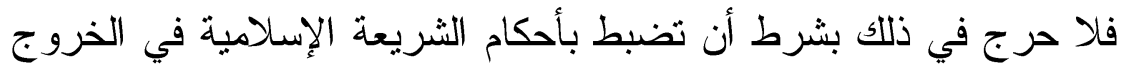

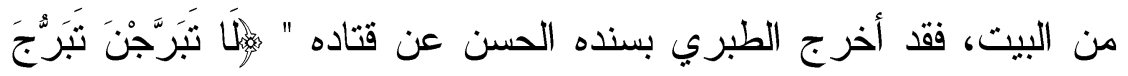

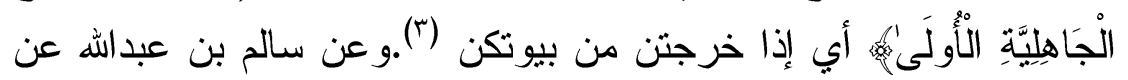

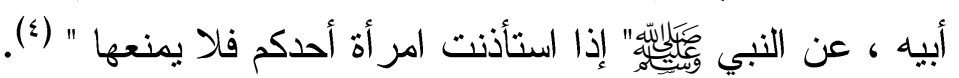

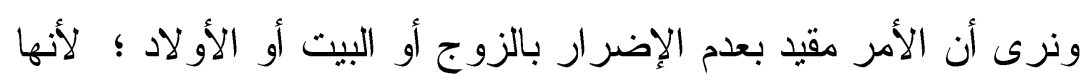

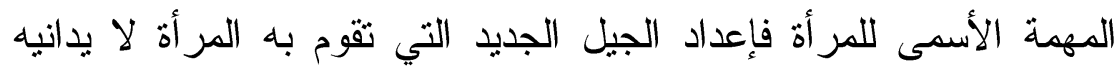

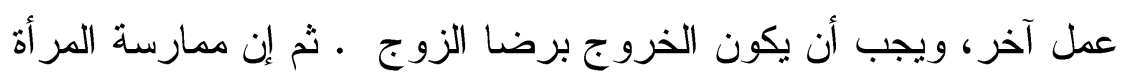

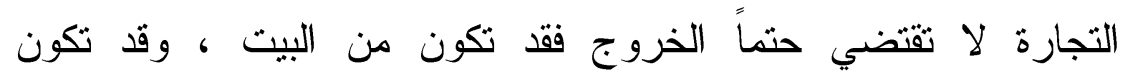
بالمشاركة كما صنعت أم المؤمنين خديجة رضى الله عنها ، بل إن الأمر

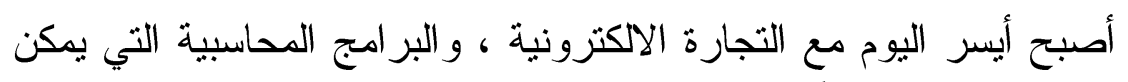

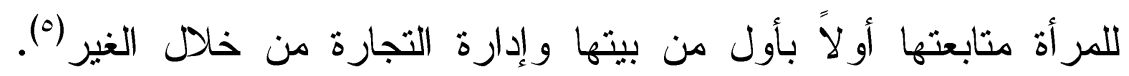

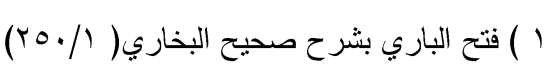

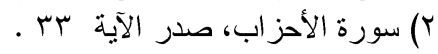

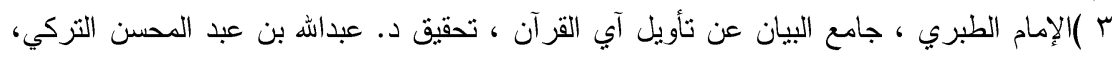

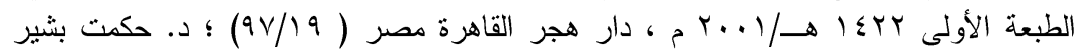

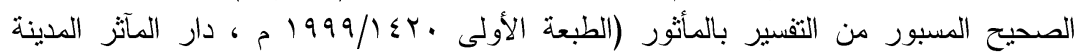

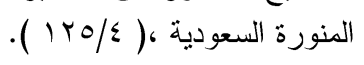

؛ ) البخاري ، صحيح البخاري ، كتاب الآذان ، أبو اب صفة الصلاة ، باب استئذان المرأة زوجها

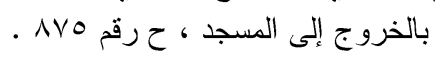

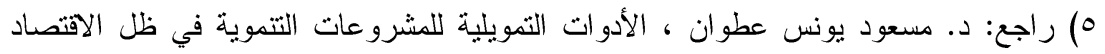

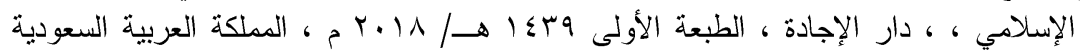

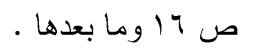


التجارة

وفي الأنظمة السعودية : يقضى قرار مجلس القوى العاملة رقم (1/م 19

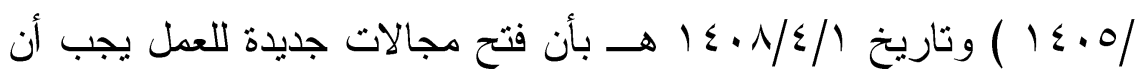

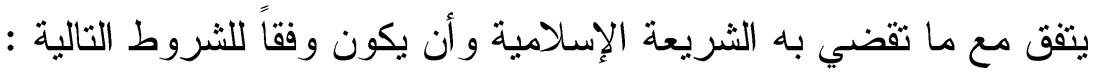

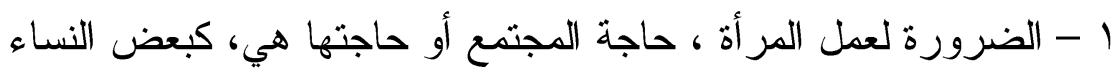
المعيلات وقد رأيتهن يبعن في السوق المجاور للحرم النبوي الثريف.

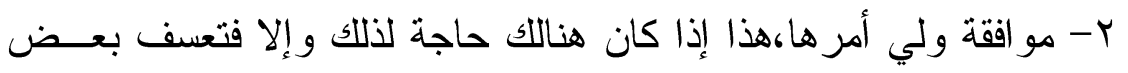

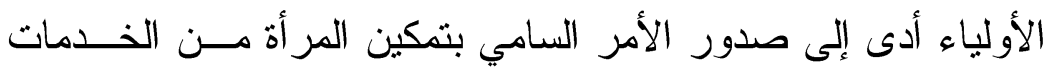

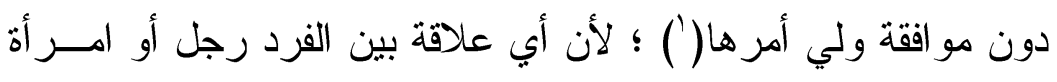
وبين الدولة لا تشترط مو افقة شخص آخر لإتمام تلك العلاقة (r).

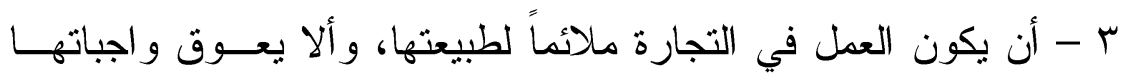

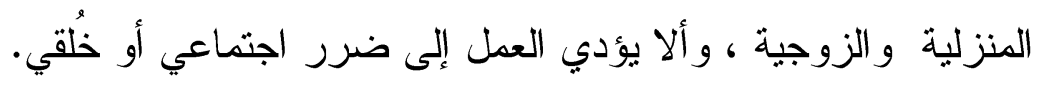

( )حيث وجه خادم الحرمين الثريفين الملك سلمان بن عبدالعزيز آل سعود - حفظه الله - بعدم

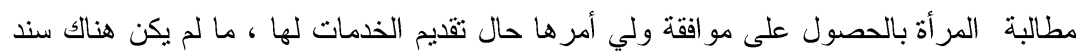

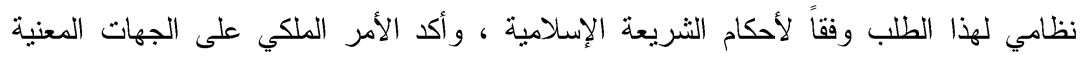

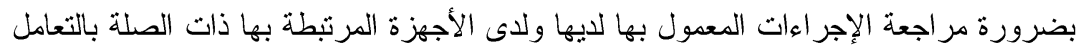

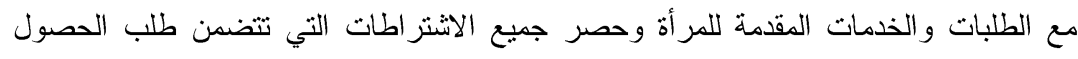

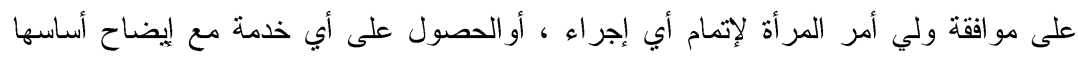

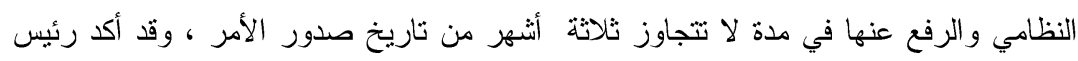

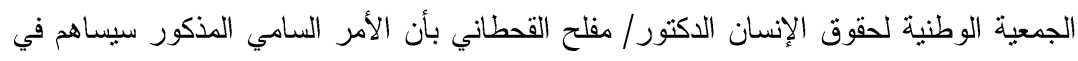

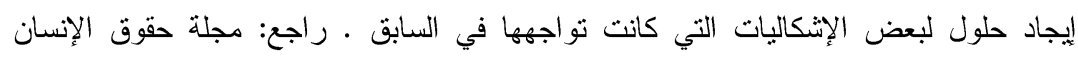

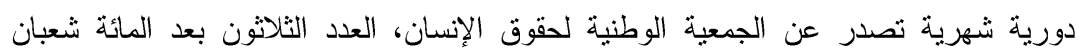

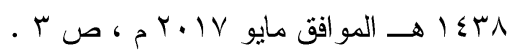
r ) تعليق رئيس الجمعية الوطنية لحقوق الإنسان بالمملكة العربية السعودية في نعليقه على القرار

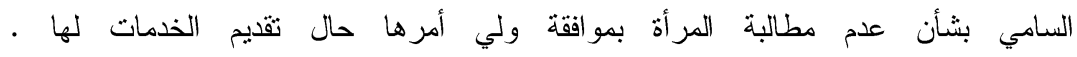
راجع :مجلة حقوق الإنسان دورية شهرية تصدر عن الجمعية الوطنية لحقوق الإنسان ، العدد

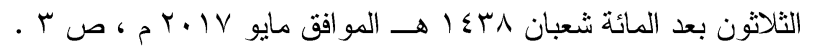


ـ - أن تؤدي المر أة عملها في تجارتها في مكان منفصــل تمامــاً عـن

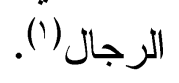

ونرى أن هناك من الأعمال الكثيرة في مجال التجار ات و الأعمال تخص

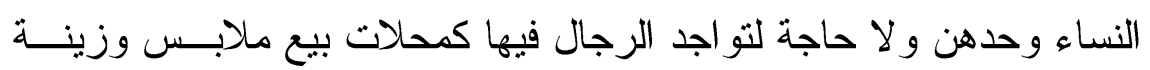

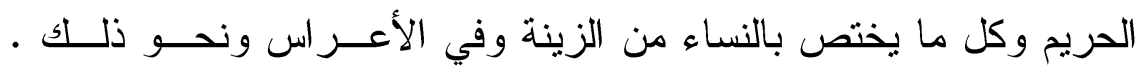

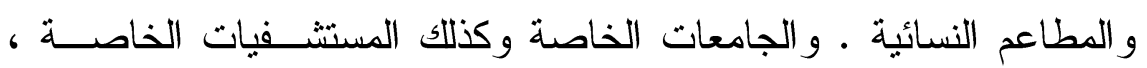

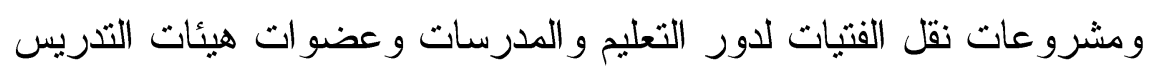

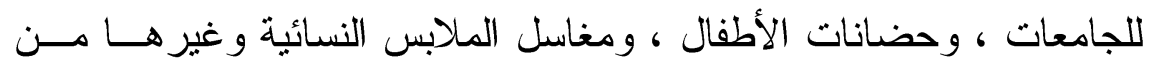

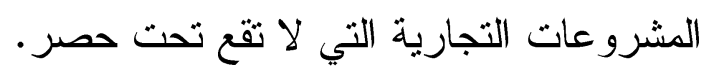

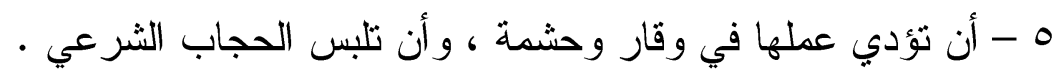

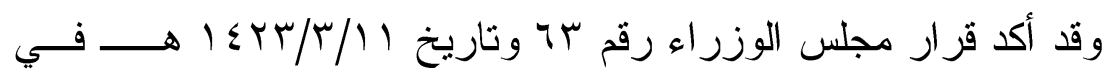

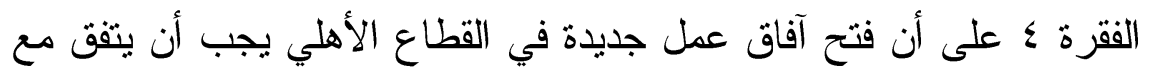
أحكام الثريعة الإسلامية وفي ضوء وان ما ورد في قرار مجلس القوى العاملة

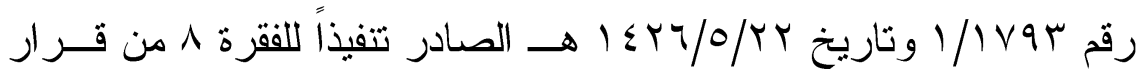

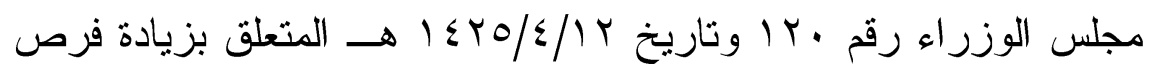

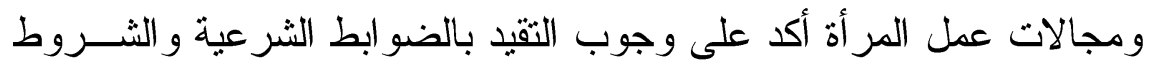

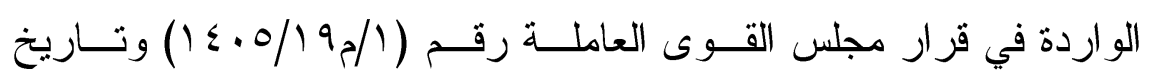

$$
\cdot(r) \cdot 1 \leqslant \cdot 1 / \varepsilon / 1
$$

(1) ويرى جانب من الفقه أنه أصبحت مسألة الاختلاط تمثل مبدأ يتسم بالتفاوت وفقاً لطبيعة النشاط

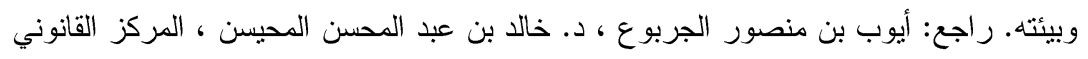

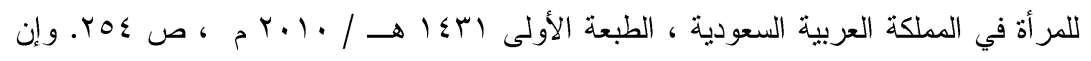

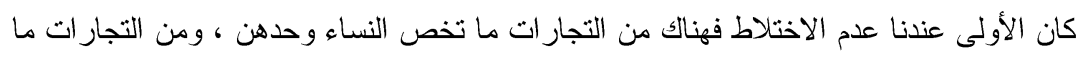

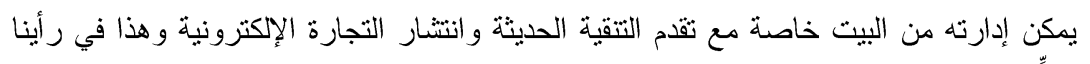

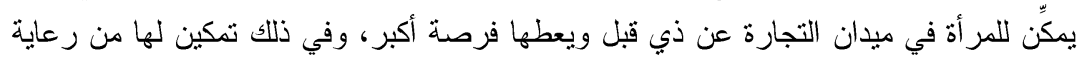

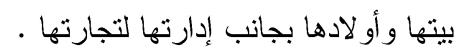

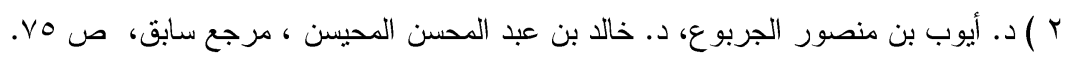


" أحقية المرأة في ممارسة التجارةودورها في تحقيق رؤية المملكة •ب.r ( دراسة مقارنة ...

المبحث الثالث

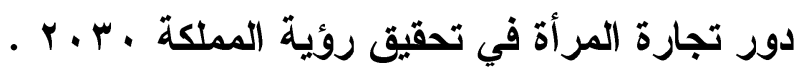

تمهي⿻ وتقنيم:

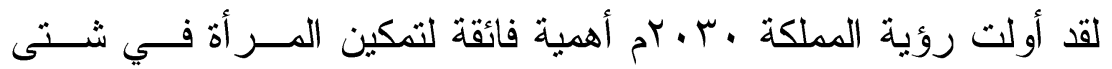
مجالات الحياة، وذلك لدورها البارز منذ القدم في تتمية بلادهـــا ووقوفهـــا بجانب الرجل وتحملها المسؤولية معه فهي راعية في بيت زوجها ومسؤولة

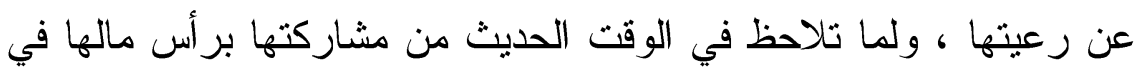
التنمية من خلال إقامة مشروعات تجارية كما هو ثابت من بيانات الغــرف التجارية ـ و ايضاح ذللك في مطلبين: المطلب الأول: عناية رؤية المملكة بتعاظم دور المر أتجاريا ـ المطلب الثاني: مساهمة تجارة المر أة في تحقيق الرؤية. المطلب الأول

عناية رؤية المملكة بتعاظم دور المرأة تجاريا

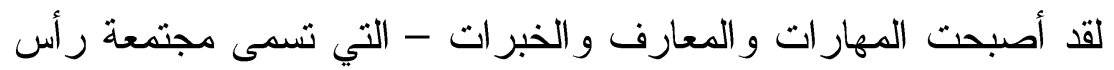
المال البشري - تشكل نسبة هائلة من الثروة العالمية أكبر من رأس المــال

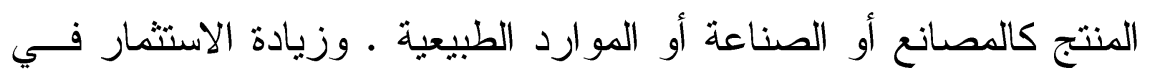
هذا الجانب تعنى تمكين المرأة وتعزيز مشاركة المر أة في القوى العاملـــة وملكية الأعمال وتحسين الإنتاجية يمكن أن تضيف المليار ات إلى الاقتصاد

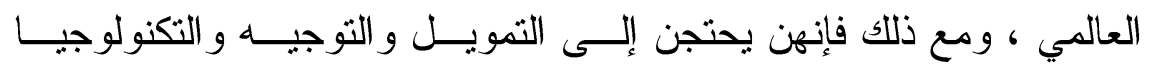
و المعرفة (') ـ و هذا ما أكدث عليه رؤية المملكة حيث جاء فيها :" لســــــا

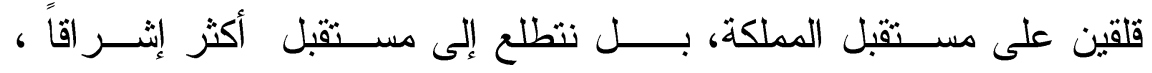

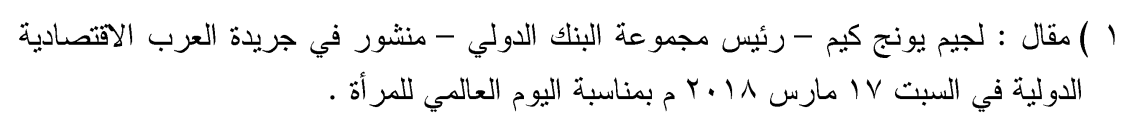




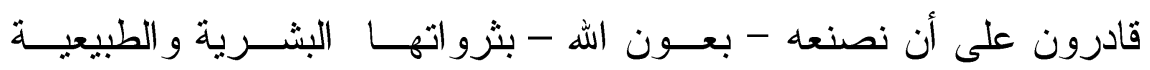

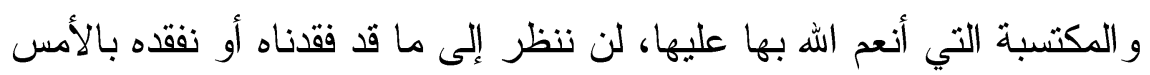

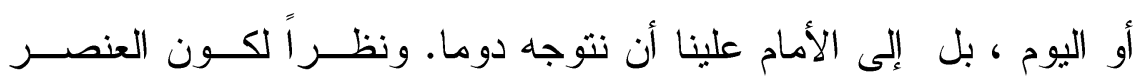

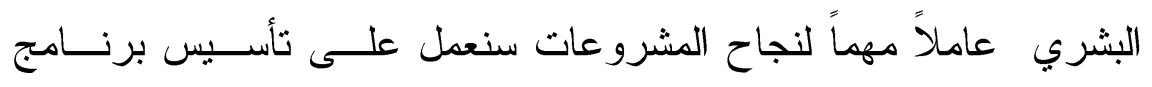
متخصص لدعم وتفعيل هذا العنصر المهم ، وسيعنى البرنــامج بتحقيـق

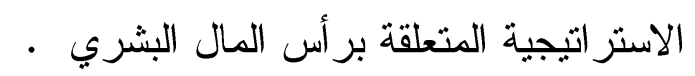

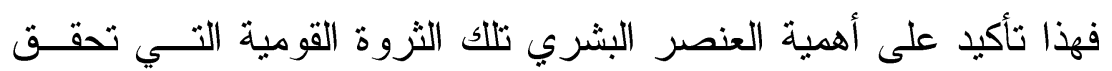

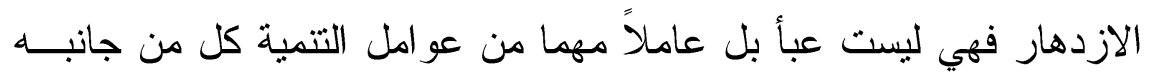
رجالاً ونساء . رلاء

ونرى أن مشاركة المر أة في ميدان الأعمال المتعلقة بها يؤدي إلى تحسين جودة الحياة وزيادة قدرة البلدان على الازدهار في الاقتصاد العالمي وهـــا

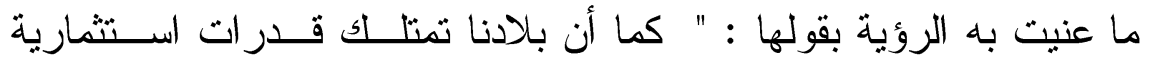

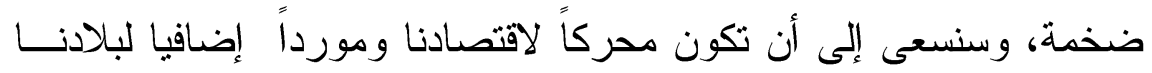

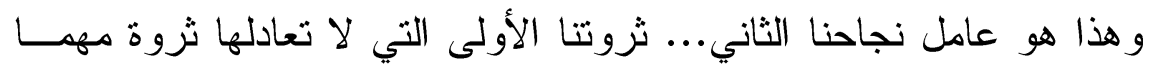
بلغت شعب طموح معظمه من الثباب(')، هو فخر بلادنا ولا ننسى أنـــه بسو اعد أبنائها قامت هذه الدولة في ظروف بالغة الصعوبة، عندما وحـــدها

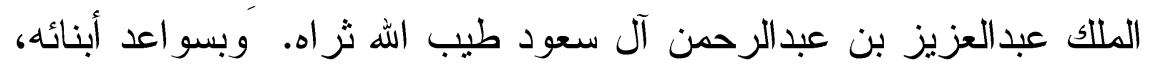
سيفاجئ هذا الوطن العالم من جديد. ومن الأفكار الجديرة بالرعاية نظــام

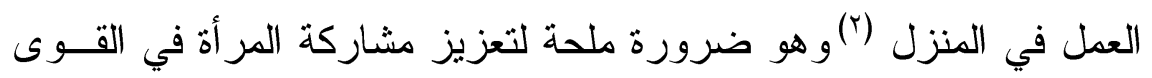

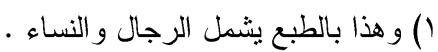

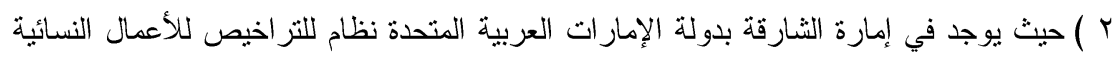

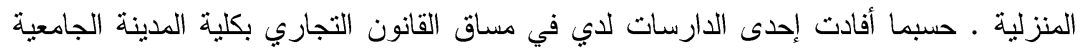

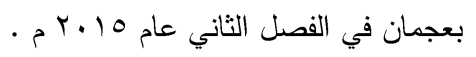




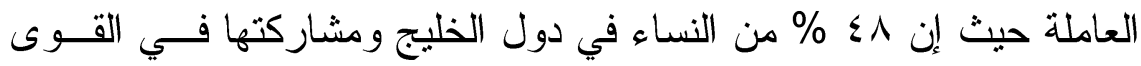

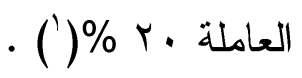

ولهذا عملت رؤية المملكة على تعزيز دور المرأة والعمل على تمكينها للاستفادة من رأس المال البشري ومن الاستفادة مما تملكه من رأس المال في الاستثمار بما يؤدي في النهاية للمزيد من التنمية والتقدم ؛ حيث ورد فيها :" ما نطمح إليه ليس تعويض النقص في المداخيل فقط، أو المحافظة على المكتسبات و المنجزات، ولكن طموحنا أن نبني وطناً أكثر ازدهارا

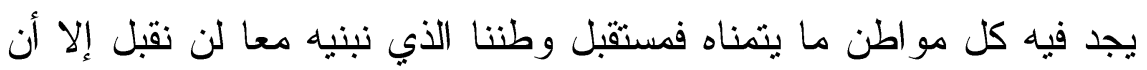
نجعله في مقدمة دول العالم، بالتعليم والتأهيل، بالفرص التي نتاح

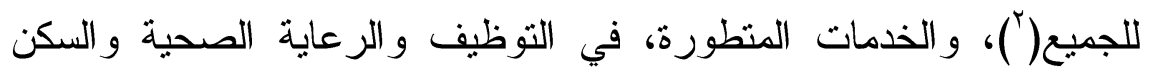
و التزفيه، وسنفتح مجالاً أرحب للقطاع الخاص ليكون شريكا، بتسهيل أعماله، وتشجيعه، لينمو ويكون واحدا من أكبر اقتصادات العالم، ويصبح محركا لتوظيف المواطنين ، ومصدرا لتحقق الازدهار للوطن و الرفاه للجميع. هذا الوعد يقوم على التعاون والثراكة في تحمل المسؤولية، ونؤمن بتطوير أدواتتا الاستثمارية، لإطلاق إمكانات قطاعاتتا الاقتصادية الو اعدة وتتويع الاقتصاد وتوليد فرص العمل للمو اطنين".

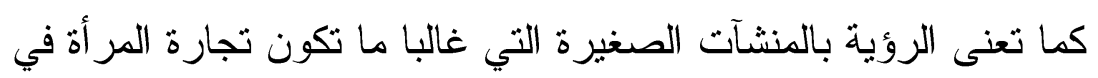

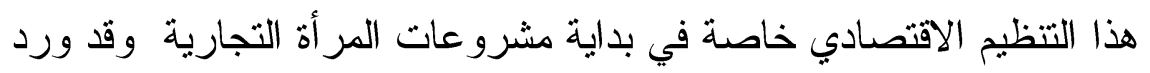

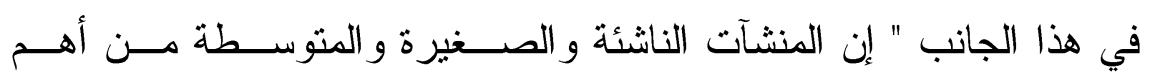
محركات النمو الاقتصادي، إذ تعمل على خلق الوظائف ودعــم الابتكـــار

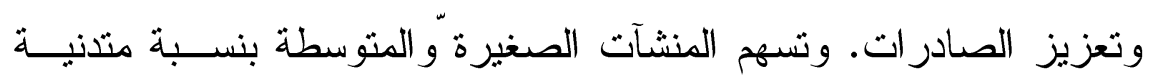




\section{مجلة كلية الدراسات الإسلامية والعربية بنات - دمنهور العدد الثاني - المجلد السابع Vا.rم م}

بالاقتصادات المتقدمة. سنسعى إلى خلق فرص توظيف مناسبة للمــو اطنين في جميع أنحاء المملكة عن طريق دعم ريادة الأعمال وبر امج الخصخصة و الاستثمار في الصناعات الجديدة. وفي هذا الصدد، قمنا بتأســيس الهيئــة العامة للمنشآت الصغرية و المتوسطة، وسنو اصل تشجيع شباب الأعمال على ولى النجاح من خلال سن أنظمة ولوائح أفضل ، و إيجاد طرق تمويل أيسـر .

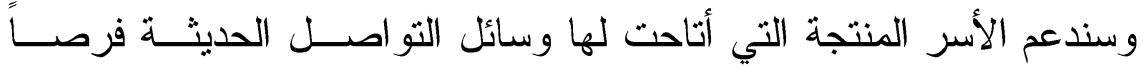
تسويقية و اسعة . كما عنيت الرؤية بالتدريب و التأهيل للرجال و النســاء دعمـــاً لنهـوض وض الجميع بمشروعاتهم الاستثارية حيث نصت الرؤية على " سيمنح اقتصادنا الفرص للجميع، رجالا ونساء ، صغار ا وكبار ا ؛ لبسهمو ا بأفضل ما لــديهم من قدرات، وسنركز على التدريب المســتمر الــذي يــزود ابناؤنـــا بمــــا بالمهار ات التي يحتاجونها ، وسنسعى إلى تحقيق أقصى استفادة من قدر اتهم عبر تشجيع ثقافة الأداء. ولتتسيق الجهود في تحقيق ذلك قمنا بتأسيس هيئة توليد الوظائف ومكافحة البطالة.

إن من أهم عو امل قوتتا هو شبابنا المفعم بالحيوية و النشاط وبخاصة إذا

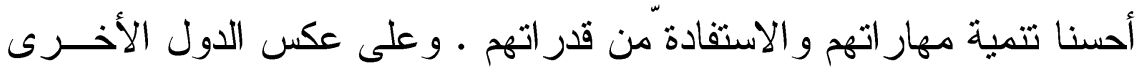
التي يساورها القلق من تقدم سكانها في السن، إن أكثرمن نصف السعوديين تقل أعمار هم عن خمسة وعشرين عاماً ، ويشكل ذلك ميزة يجب أن نحسن لهن

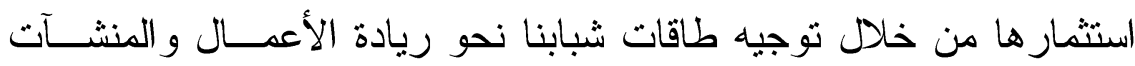
الصغيرة و المتوسطة. وأخيراً أكدت الرؤية على أهمية دور المر أة داخلياً بــلـ ودوليــاً بعــدما شملتها مع الرجال على اعتبار أنها الجزء الركين مــن الثــروة البشــرية

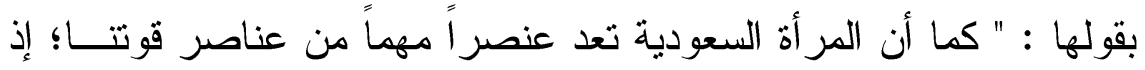
تشكل ما يزيد على •0 \% من إجمالي عدد الخريجين الجامعيين وسنستمر 
في تتمية مو اهبها و استثمار طاقاتها وتمكينها من الحصول علــى الفـرص المناسبة لبناء مستقبلها و الإسهام في تتمية مجتمعنا و اقتصادنا ، ورفع نسبة هونة

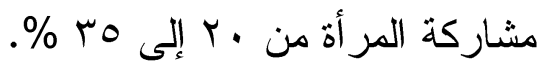

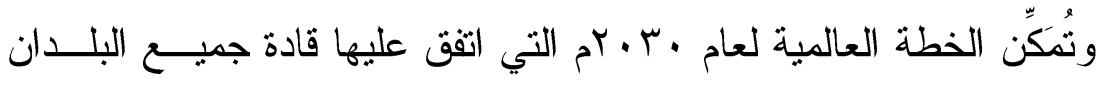

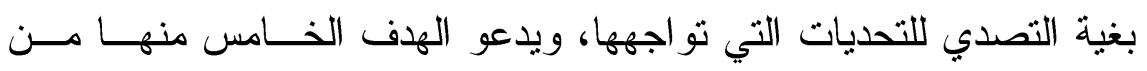
أهداف التنمية المستدامة إلى تمكين المر أة، حيث جاء فيها :" و إنني ملتـزمز بزيادة مشاركة المر أة في جهودنا لبسط السلام و الأمن ، ويزيد قيام النســاء بالمفاوضات من فرص تحقيق السلام المستدام" (').

\section{المطلب الثاني}

\section{مساهمة تجارة المرأة في تحقيق الرؤية.}

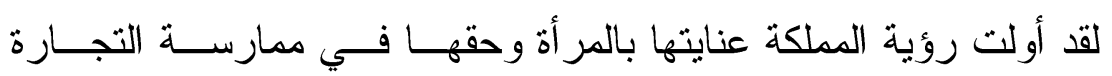

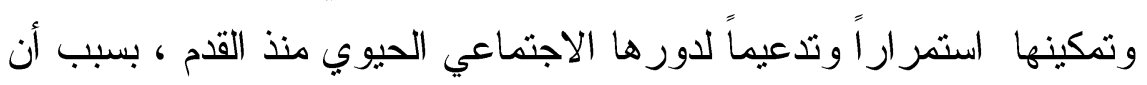
الرجل كان يترك البيث لفترة طويلة سعياً لطلب الرزق و الجهاد في سـبيل

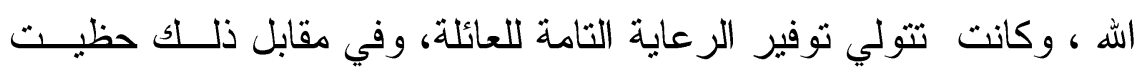

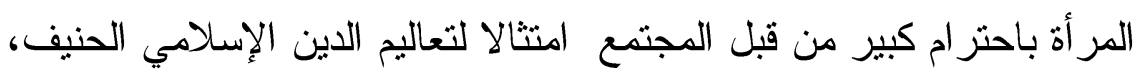

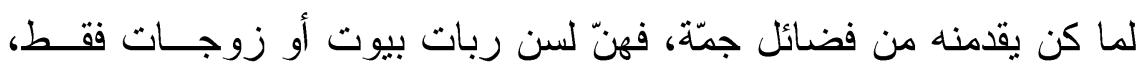
و إنما الركن الأساس في إدارة المنزل . ولقد تعزز دور المر أة السعودية، و اكتسب أبعاداً جديدة مع نطور المملكة

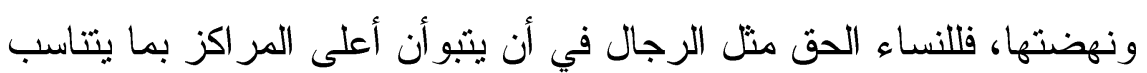

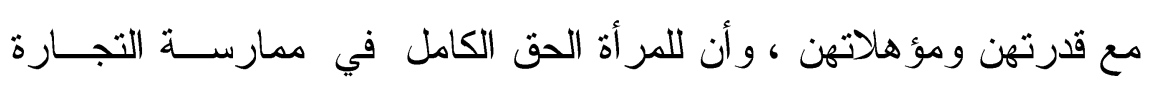

1 )مجلة حقوق الإنسان دورية شهرية تصدر عن الجمعية الوطنية لحقوق الإنسان ، العدد الثثلثون

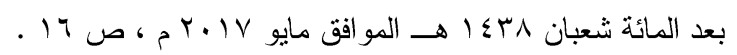


فضلاً عن التعليم و العمل و الوظائف مثلها مثل الرجال وذلك فــي نطــاق

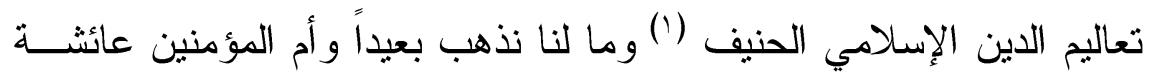
تتصدق من كسبها وأن أطيب الصدقة ماكان من كسب البد . وقد كثفت بيانات للبنك الدولي عن تتامي دور النساء في مجــال المــال

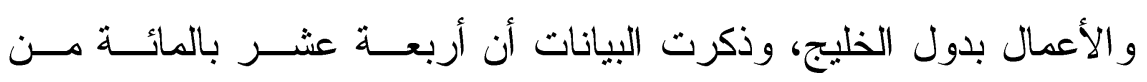

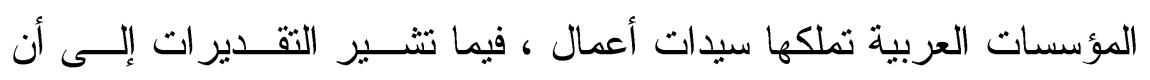
إجمالي حجم ما نملكه سيدات الأعمال في المملكة العربية السعودية يتجاوز خمسة وأربعون مليار ريال في البنوك السعودية كما تبلغ قيمة الاستثمار ات

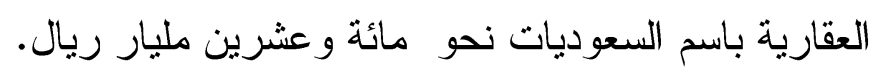
كما أن عشرين بالمائة من السجلات التجارية في المملكة بأسماء نســاء ماتهاء

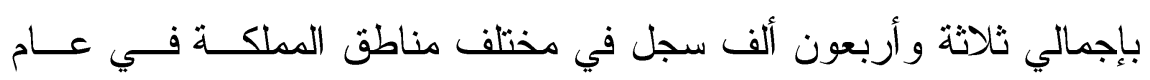

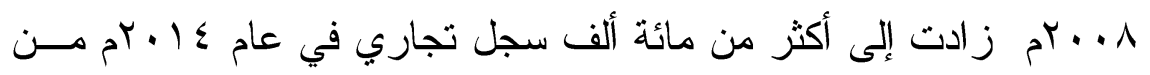
إجمالي تسعمائة ألف سجل تجاري. وقد أثبتت در اسة إحصائية أعدها مركز السيدة خديجة بنت خويلد التـابع للغرفة التجارية الصناعية بجدة، إلى أن مشاركة رؤوس الأموال النســائية تخصصت في استثمار ات جريئة ومربحة تدير ها سيدات أعمال سعودي اتو ارتفع حجم رؤوس الأمو ال النسائية في المملكة الى ستين مليار ريال ، و أن أكثر من عشرين في المائة من الأموال الموظفة في صـــناديق الاســتشمار

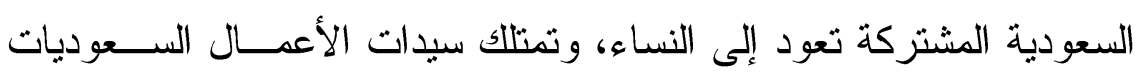
نسبة تصل إلى خمس وسبعين في المائة من مدخر ات المصارف السعودية.

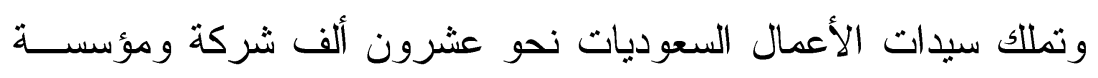

(1) نتكل المر أة 1) (1\% من القوى العاملة في المملكة ، وتبلغ نسبة مشاركتها في قطاع الدولة

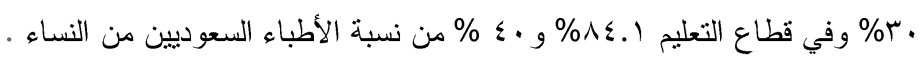


صغيرة ومتوسطة ،كما يشارك عدد من الســيدات فـي مجــالس الغــرف التجارية في الرياض وجدة و غيرهما.

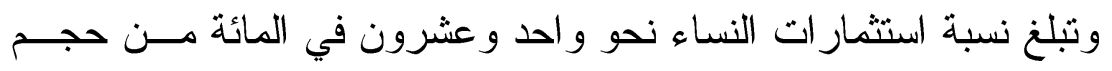
الاستثمار الكلي للقطاع الخاص في المملكة. وهناك إقبال كبيز من المرأة السعودية على استخر اج السجلات التجارية و التوجه الاستثماري في جميع المجالات وخاصة العقارية و الأســهم التـي

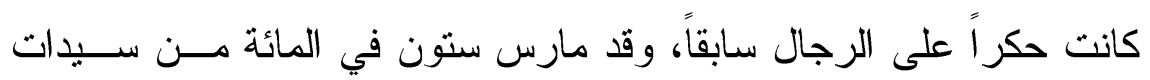

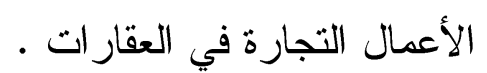
وتمثللك النساء السعوديات نحو ؟ب\% من مجموع الثركات الســعودية داخل المملكة متتوعة الأنشطة ما بين الاعمال البنائية و التصنيع، و الديكور الداخلي، و التعليم، بالإضافة إلى المو اد التجميلية و الملابس بمختلف أنو اعها،

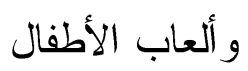
وعدد المصانع التي تمنلكها سيدات أعمال سعوديات في مدينة الريــاض

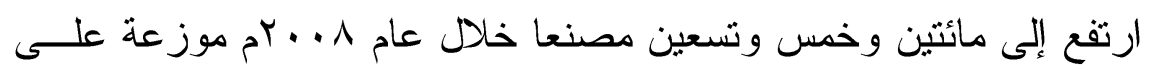
عدد من الأنشطة الصناعية المتنوعة. وقد تصدرت المصانع الكيميائية النسائية وبلغ عــددها ســبعا وســبعين

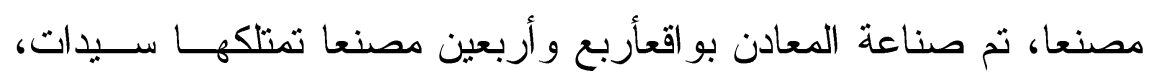

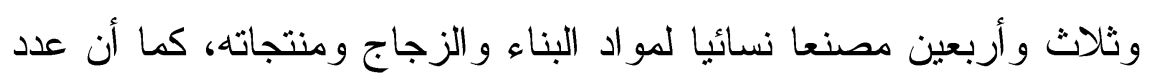

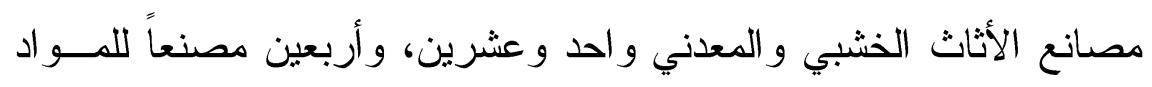

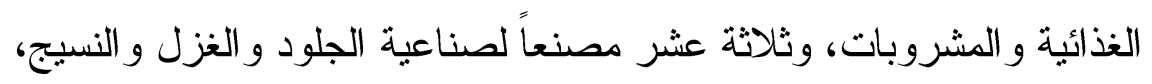

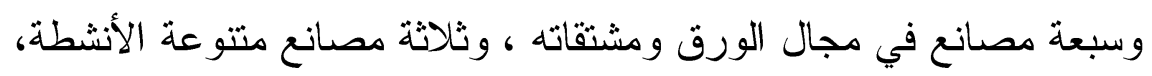

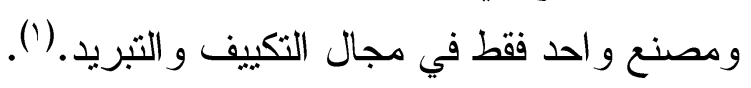

1) saudiwomen.wordpress.com/stats ، http://www.aleqt.com/2014/07/17/article_868081.ht 
وأوضحت رئيسة اللجنة الوطنية النسائية التابعة لمجلس الغرف السعودية أن هناك حو الي عشرة آلاف سيدة سعودية حالياً يعملن في مجال الاستثمار الغذائي بدون تزخيص مز اولة مهنة عادّةً وهذا مخالفاً من الناحية النظامية؛ وذلك لحاجة مثل هذه الأعمال للعملية الرقابية، وقالت إن هناك محاو لات مع درة وزارة الثؤون البلدية و القروية للمطالبة بعمل نز اخيص للقيــام بزيــار ات

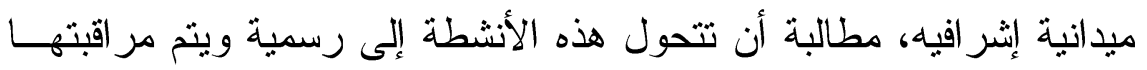
من قبل الجهات الرقابية المعنية بها؛ لما فيها من خطورة على المستهلك.

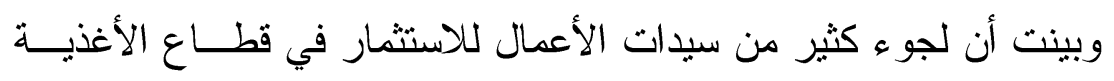

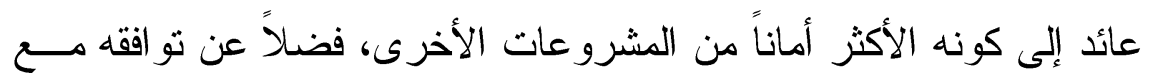

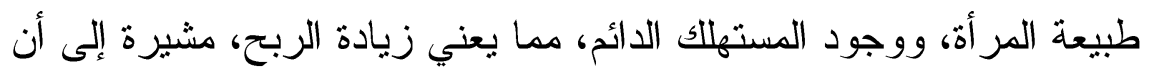

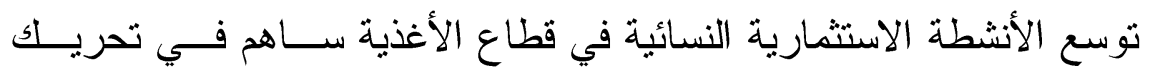
الأمو ال النسائية في المملكة المجمدة التي تقدر بالمليار ات وذلك فـي حـــال قامت تلك الأنشطة الاستثمارية من خارج المنزل عن طريق التصنيع وزيادة

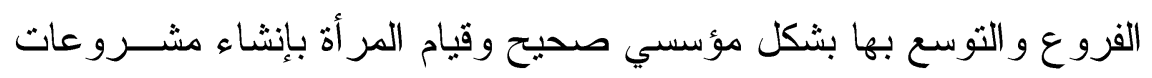
كبيرة في ذات القطاع. كما أشارت سيدة الأعمال ومؤسسة تنظيم المعارض وض المؤتمر ات بالمملكة

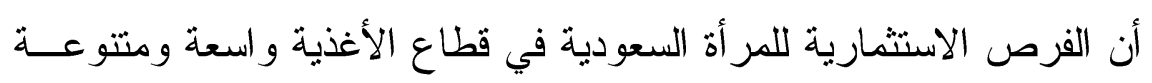

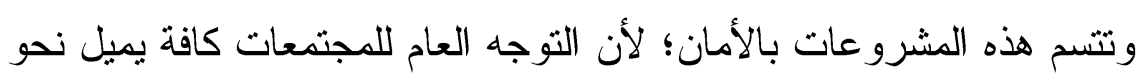
الاستهلاك الغذائي من خارج المنزل، وقالت : إن طبيعة المر أة جعلت منها لهان التهان

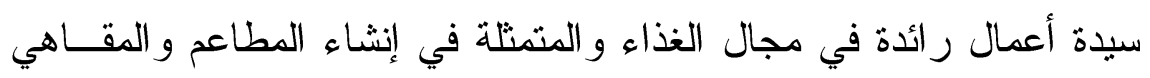
ومحلات الحلويات، مشيرةً إلى أن توسع المر أة في الأنشطة الاستثمارية في ولي جميع القطاعات و المجالات يساهم في تحريك عجلة الاقتصاد الوطنية. وذكرت إحدى سيدات الأعمال أن الاستثمار في قطاع الأغذية لقي دعماً ورواجاً كبيراً للمستثمرات السعوديات؛ لما تتميز به هذه المشروعات مــن 
المرونة؛ كونها لا تتطلب رأس مال كبير أ كبداية للمشروع، مشيرةً إلـى أن

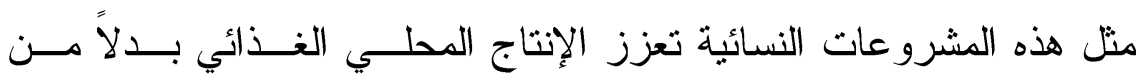

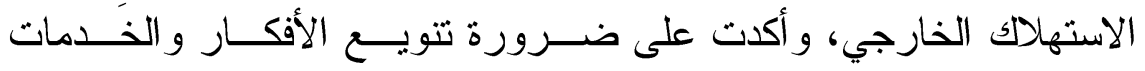

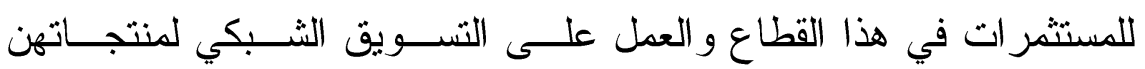

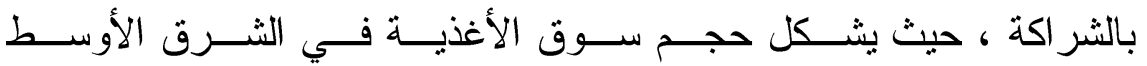
ما يقدر بمائة وستين مليار دولار سنوياً، وتستحوذ منطقة الخليج العربـي لهي منها على تسعين مليار دولار سنوياً، ويبلغ حجم استثمار سوق الأغذية في المملكة ما يقارب ستين مليار دو لار سنوياً. وفي إحصائية قام بها صندوق النقد الدولي ذكر فيها أن عدد سيدات الأعمال السعوديات تجاوز ثلاثين ألف سيدة، ممن يمتلكن سجلات تجارية، وأن حجم الأمو ال الر اكدة بالبنوك للسيدات وصل إلى خمس وستين مليار اً. وهذا ما أكدت عليه السكرتيرة الثالثة في الوفد السعودي الدائم لدى

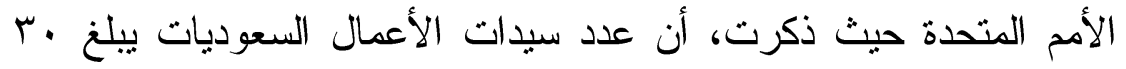
ألف سيدة ، وأن حجم الاستثمار ات العقارية للنساء السعوديات ييلغ مليار دولار، وأن عدد المشاريع الصغيرة والمتوسطة التي تتر أسها المرأة يصل أكثر من • r ألف مشروع، فيما أصبح حجم الاستثمار ات النسائية في المملكة أكثر من اYY\% من حجم الاستثار الكلي للقطاع الخاص، و أكثر من ·r\% من الأموال الموظفة في صناديق الاستثمار السعودية

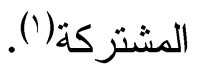

() وذلك في كلمتها ضمن أعمال البند الرابع و العشرين في الأمم المتحدة بشأن القضاء على الفقر

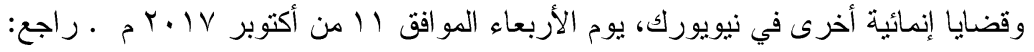
ttp://www.aleqt.com/2014/07/17/article_868081.ht 
ومجمل القول أن تحريك الاستثمار بالأموال التي تمتلكها المر أة بدخولها

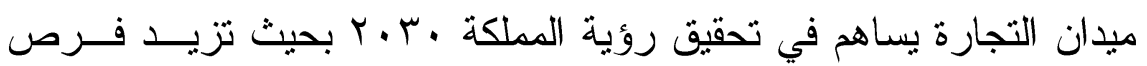

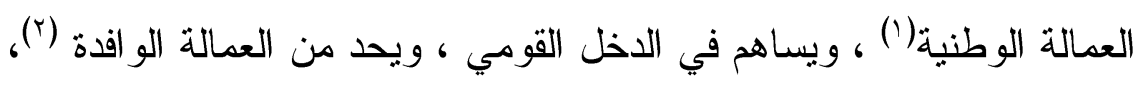

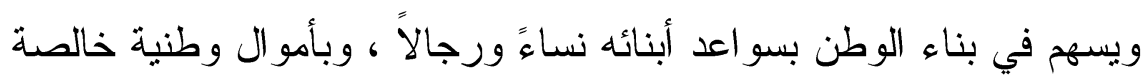

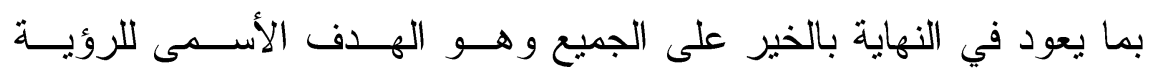

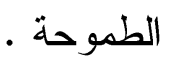

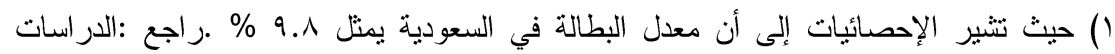

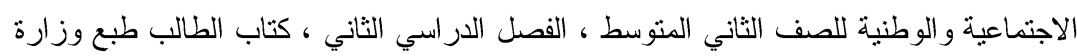

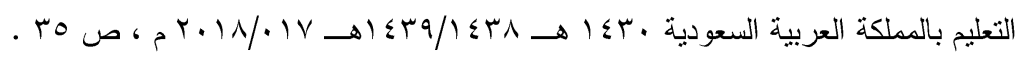

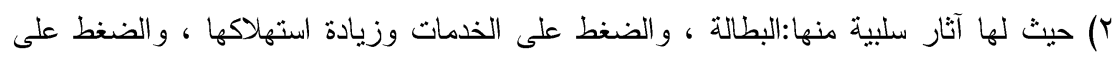

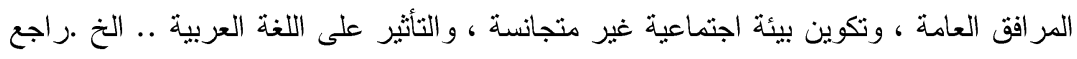

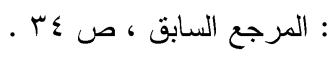




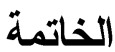

الحمد لله في البدء وفي الختام ، وبعد سبر أغوار موضوع أحقية الـــرأة

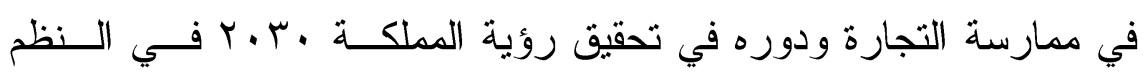
الوضعية و الثريعة الإسلامية فقد خلص إلى عدة نتائج ، التي تردف بــأهم التوصيات وذللك على الوجه الثالي: أولا: النتائج :

1 - ثبوت ممارسة المر أة التجارة تاريخياً .

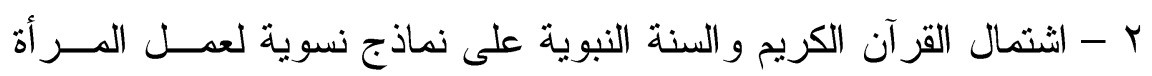

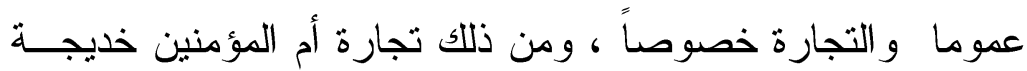
رضي الله عنها .

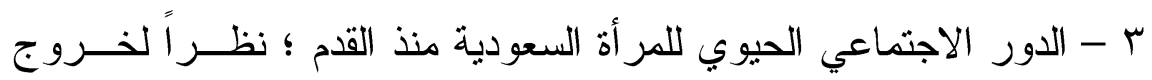

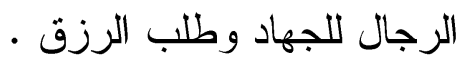

ع - مساهمة تجارة المر أة في نشر الدعوة وخدمة الدين الحنيف . ه - ثبوت أحقية المر أة في ممارسة التجارة في المو اثيق الدولية ، والــنظم

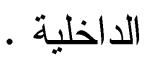
1 - عناية الأنظمة السعودية بتقريز أحقية المر أة في ممارســة التجــارة ،

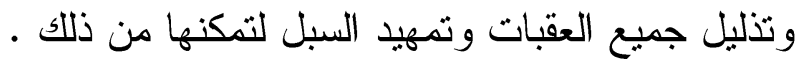

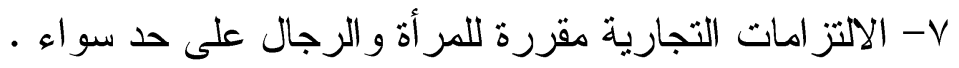

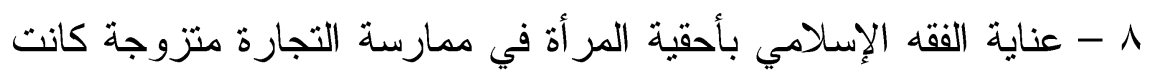
أم غير منزوجه .

9 - عدم أحقية الزوج في منع الزوجهة من من مارسة التجارة ، و إن كان لــه

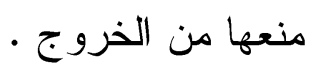

• 1 - جواز مشاركة المر أة للغير من النساء و الرجال في التجارة . 11 - 11 


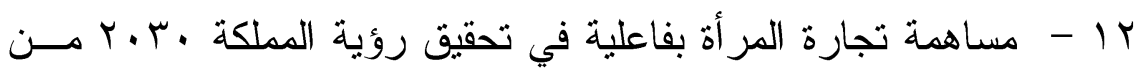

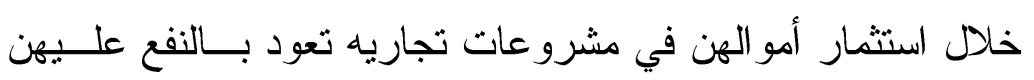

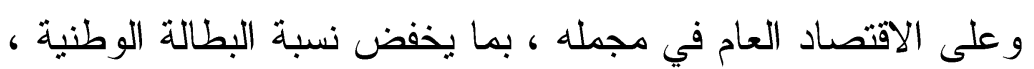
ويخفض من العمالة الأجنبية وفي ذلك منافع جمة للوطن . ثانيا: التوصيات ضرورة اكتمال البناء التشريعي للأنظمة التجارية ، بما في ذلك التجارة

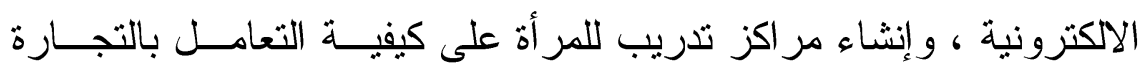
الإلكترونية، وسن الأنظمة الخاصة بممارسة و إدارة التجارة المنزلية للقضاء على التجارة العشو ائية. هذا و الله من ور اء القصد ،6، 


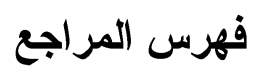

أولاً : المراجع الثرعية :

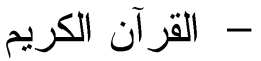

ثانياً: : التفسير وعلوم القرآن

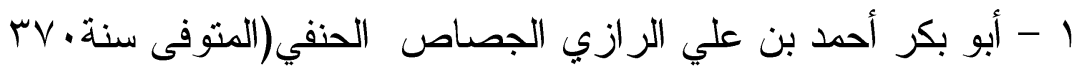

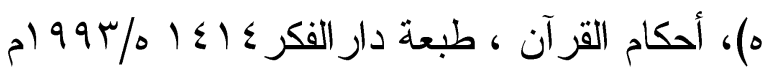
r - الإمام الطبري ، جامع البيان عن تأويل آي القرآن ، تحقيق د. عبدالله

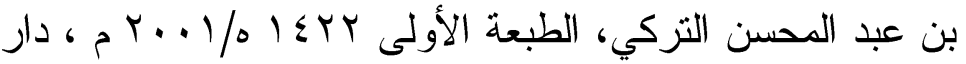

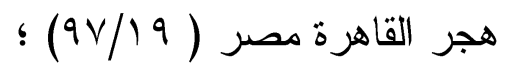

r - د. حكمت بشير الصحيح المسبور من التفسير بالمأثور (الطبعة

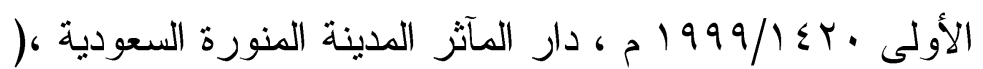

$$
\text { . ( ) }
$$

ثالثاً : كتب الحديث الشريف

1 - أبو جعفر أحمد بن محمد بن سلامة بن عبد الملك بن سلمة الأزدي

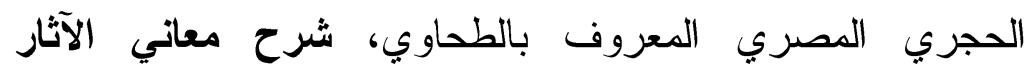
(المتوفى: ابrاه) ،حققه وقدم له:(محمد زهري النجار - محمد سيد جاد الحق) من علماء الأزهر الثريف راجعه ورقم كتبه وأبوابه وأحاديثه:د يوسف عبد الرحمن المرعشلي - الباحث بمركز خدمة الرهن

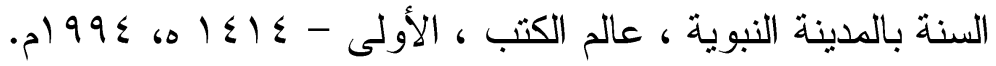

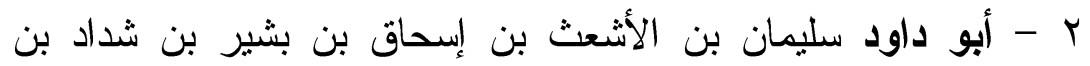

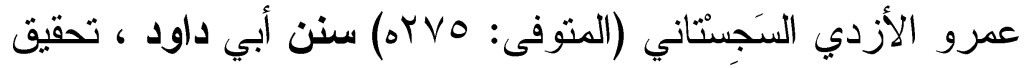

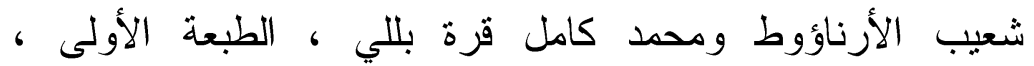

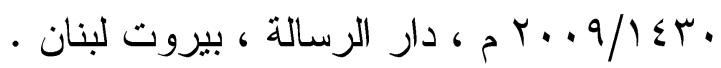
r - أبو سليمان محمد بن محمد الخطابي البستي، معالم السنن ، المكتبة

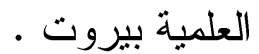


ع - أبو عبد الله محمد بن سعد بن منيع الهاشمي بالولاء، البصري،

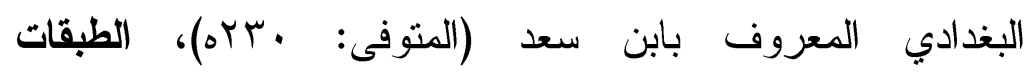
الكبرى،تحقيق: محمد عبد القادر عطا الناشر: دار الكتب العلمية بيروث.

ه - الإمام أبي عبد الله محمد بن إسماعيل بن إبر اهيم ابن المغيرة بن

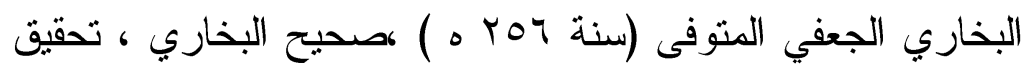

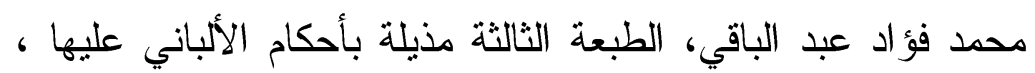

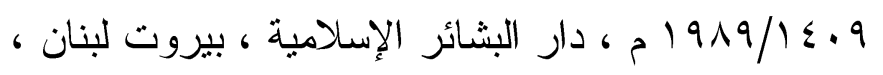

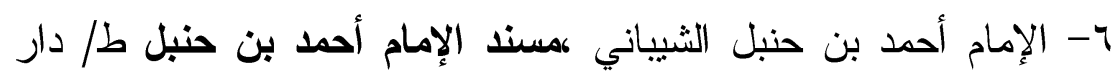

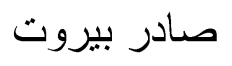

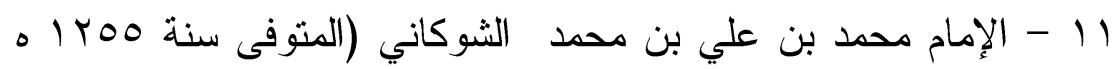

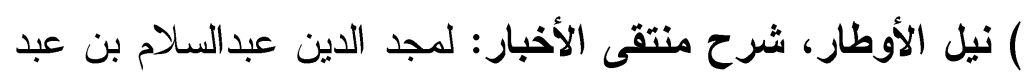

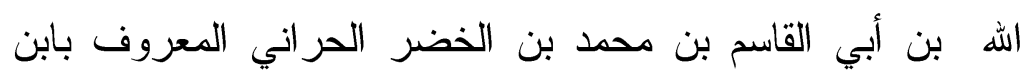
تيمية ، طبعة دار الجيل بيروت.

- V أيوب ابن قيم الجوزية، عون المعبود على سنن أبي داود، ومعه: شرح ابن القيم، المحقق: عبد الرحمن محمد عثمان ، الناشر:

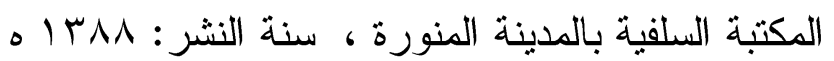

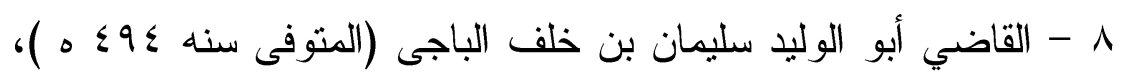

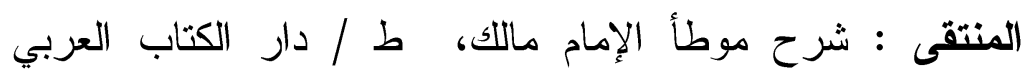

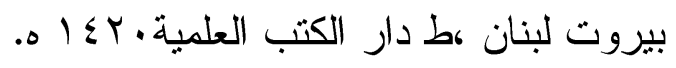


كتب اللغة :

1

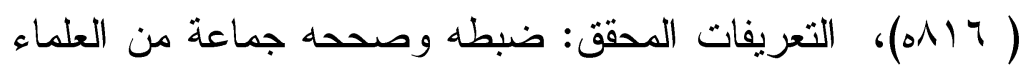

بإشر اف الناشر : دار الكتب العلمية بيروت -لبنان الطبعة: الأولى.

r - محمد رواس قلعجي، معجم لغة الفقهاء، دار النفائس للطباعة و النشر

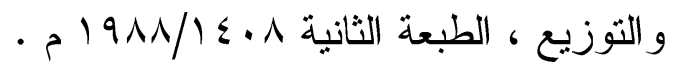

كتب التراجم : (أن

1 - أحمد بن حجر العسقلاني ، الإصابة في تمييز الصحابة ، بيروت ،

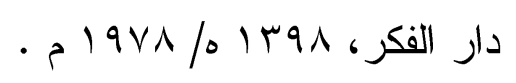

r - د. أحمد شلبي ، موسو عة الحضارة الإسلامية ، جزء الحياة

الاجتماعية في الفكر الإسلامي ، الطبعة الخامسة النهضة المصرية

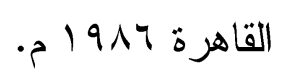

r - أسبار للار اسات و البحوث و الإعلام ، معجم أسبار للنساء السعوديات

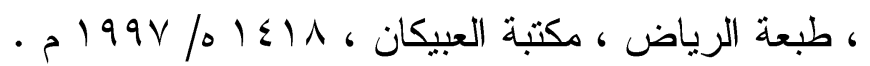

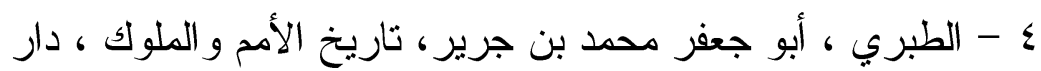

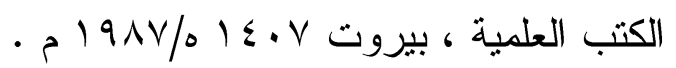

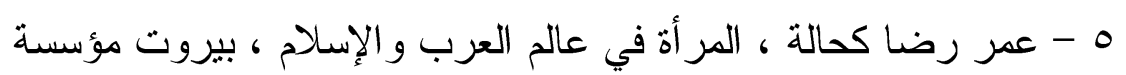

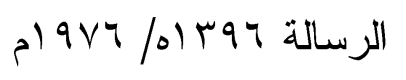

7 - د. محمد سعيد مبيض ، موسوعة حياة الصحابيات ، سوريا ، دار

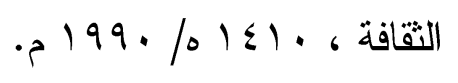

كتب الفقه :

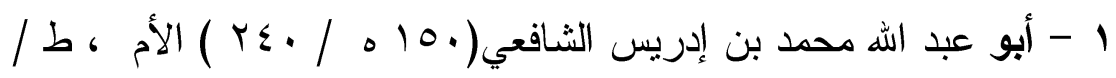

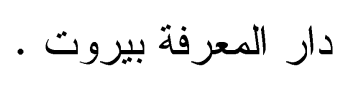

r - شمس الدين أبو عبد الله محمد بن محمد بن عبد الرحمن الطر ابلسي

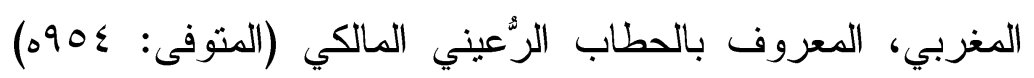


كمو اهب الجليل في شرح مختصر خليل ، الناشر:دار

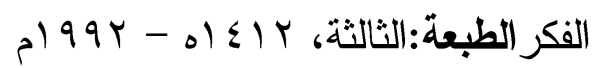

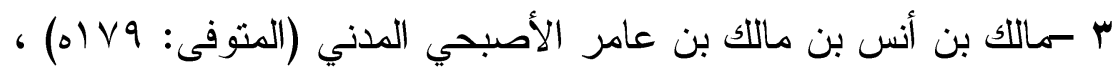

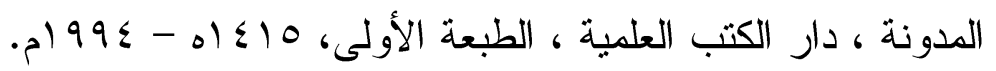
ـ - منصور بن يونس بن إدريس البهوتى كثاف القناع (على منن الإقناع

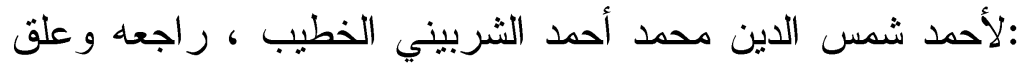

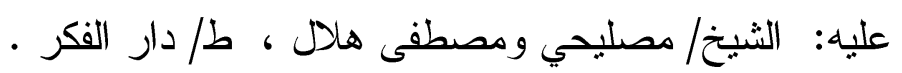

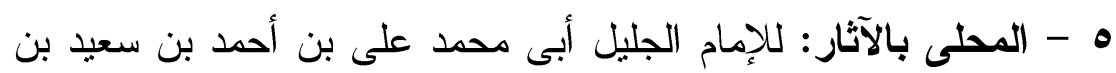
الأندلسي بن بن بن بن

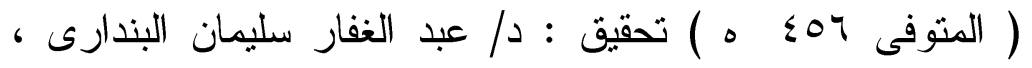

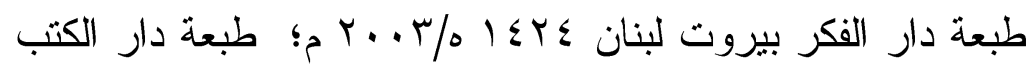

$$
\text { العلمية بيروت لبنان. }
$$

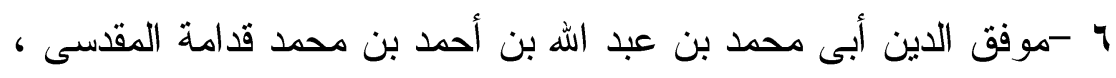

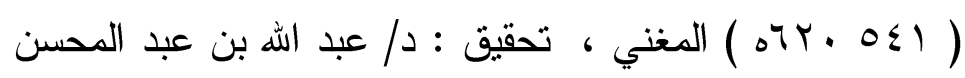

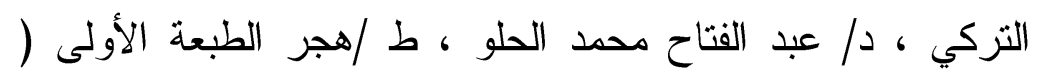

$$
\text { . ( ) } 9 \wedge \vee 0) \leqslant \cdot \Lambda
$$

- موفق الدين عبداله بن أحمد بن قدامة): لأبى إسحاق برهان الدين

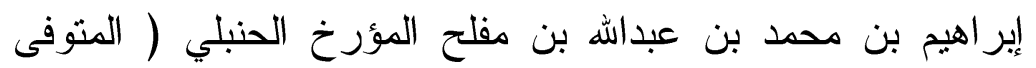

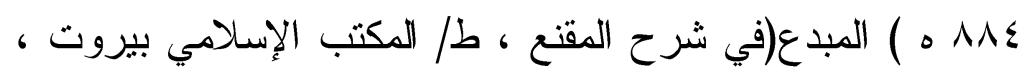

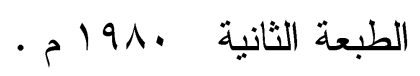

\section{مؤلفات حديثة متنوعة :}

1 - أيوب بن منصور الجربوع ، د. خالد بن عبدالمحسن المحيسن ،

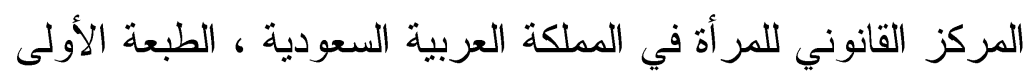

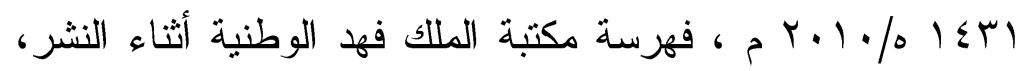

$$
\text { ردمك }
$$


r الدر اسي الثاني ، كتاب الطالب طبع وزارة التعليم بالمملكة العربية

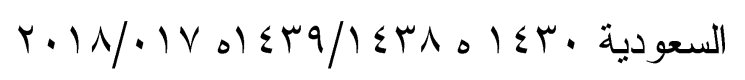

r - د. حنان أحمد عبدالعزيز القطان ، عمل الزوجة وأثزه في نفقتها الثرعية " دراسة فقهية مقارنة " رسالة دكثور اه ـ سلسلة الرسائل الجامعية . النز

ـ - د. خلف بن حمود بن سالم الثغدلي ، و آخرون ، عمل المرأة في الحسبة و أحكامه الفقهية ومقاصده الثرعية وضرورتنه الاجتماعية

$$
\cdot 0 r \cdot 1 v / 1 \leqslant r \Lambda
$$

ه - د. سعد الراشد .زبيد هدرب ، طريق الحج من الكوفة إلى مكة ،

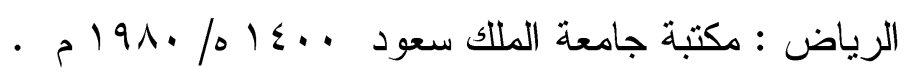

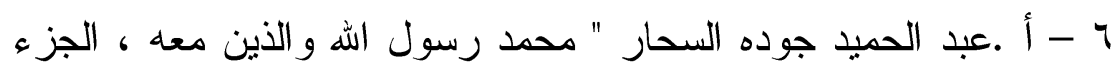
الثامن خديجة بنت خويلد ، طبعة سنة 9 VVV م. 19 م.

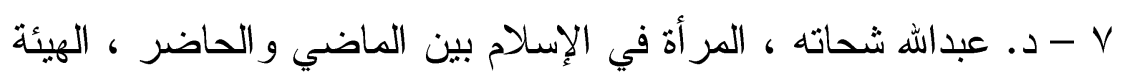

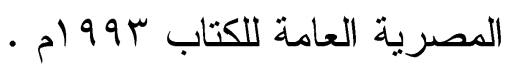
1 - أ. مصطفى أبو المعاطي ، . 10 قصة من حياة خديجة بنت خويلد

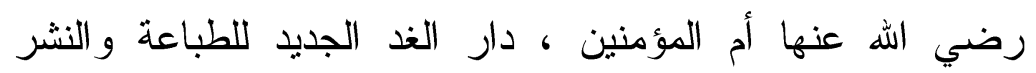

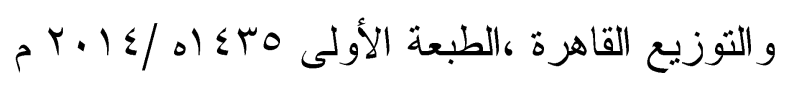

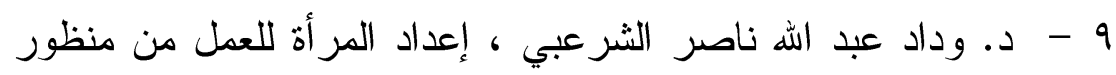

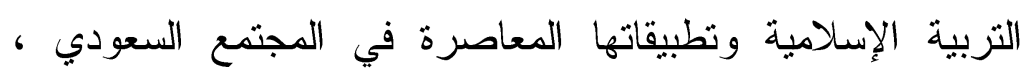

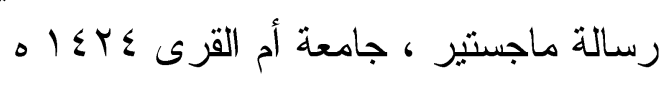

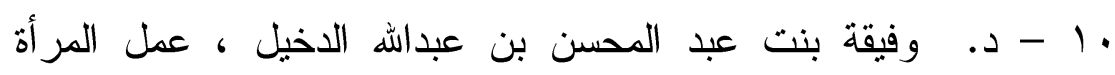

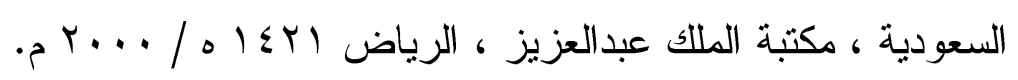

$$
\text { المراجع القانونية : }
$$

1 -د. أنس قاسم جعفر، الحقوق السياسية للمر أة في الإسلام و التشريع 
المعاصر ، دار النهضة العربية .

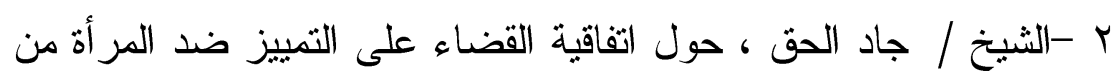

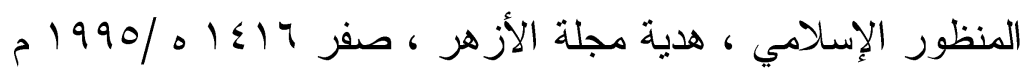

r - د. خالد مصطفى فهي ، حقوق المرأة بين الاتفاقيات الدولية

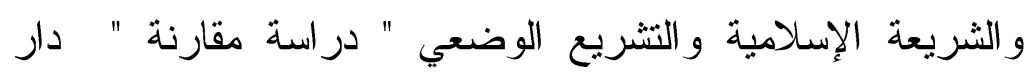

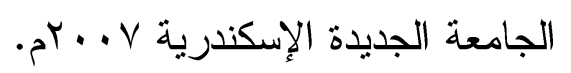

؟ - د. السيد العربي، القانون القديم دراسة عن تطور النظم القانونية

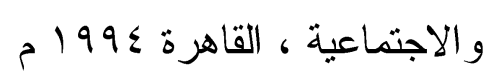

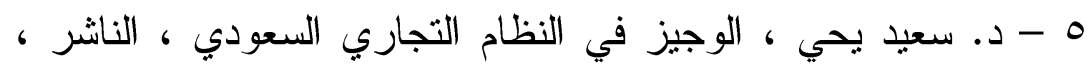

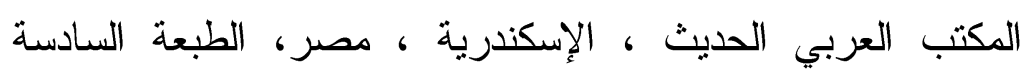

$$
\text { r. } r \text {. }
$$

7 - ـ د. عبد الحليم محمود ، المرأة المسلمة وفق الدعوة إلى الله ، دار

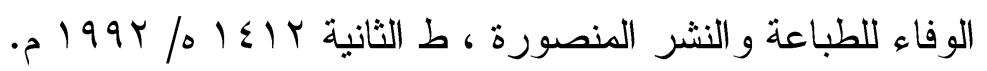
V - د. عبد الو احد محمد الفار، قانون حقوق الإنسان في الفكر الوضعي

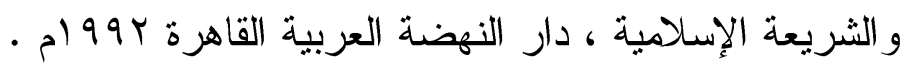
^ - د. على البارودي، القانون التجاري ، منشأة المعارف بالإسكندرية

$$
\text { م } 1917
$$

9 - د. على عبدالواحد و افي ، مشكلات مصر و العالم العربي ، دار

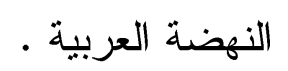

• 1 - د. علي الخفيف ، أحكام المعاملات الإسلامية ، القاهرة ، دار

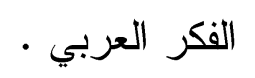

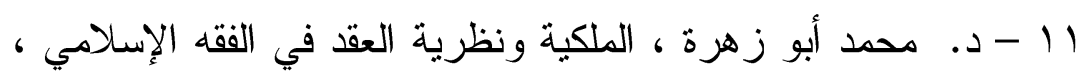

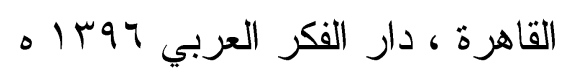

r ا - د. محمد الزحيلي ، حقوق الإنسان في الإسلام " در اسة مقارنة مع 
الإعلان العالمي والإعلان الإسلامي لحقوق الإنسان ، دار الكلم

الطيب ، دار ابن كثير دمشت سوريا بيروت لبنان الطبعة الثانية

$$
\text { م 199V01 1 11 }
$$

سا - مجلة حقوق الإنسان دورية شهرية تصدر عن الجمعية الوطنية

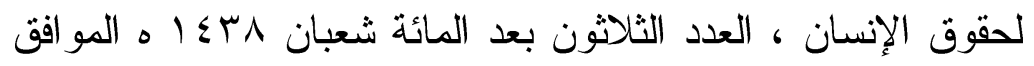

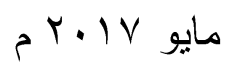

ع - الثيخ / محمد أبو زهرة ، الملكية ونظرية العقد في الثريعة

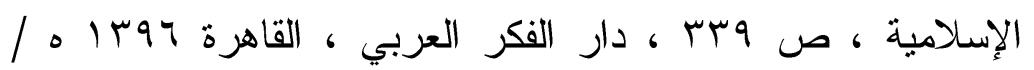

$$
\text { - } 19 \vee 7
$$

10 - د. محمد حسن الجبر ، القانون التجاري السعودي ، الطبعة الر ابعة

$$
\text { . } 1997 / 1 \leq 1 \mathrm{~V}
$$

17 - د. محمد حسني عباس ، د. على جمال الدين عوض ، القانون

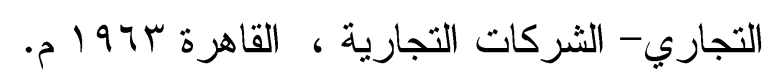

IV - د. مسعود يونس عطوان ، الأدوات التمويلية للمشروعات التتموية

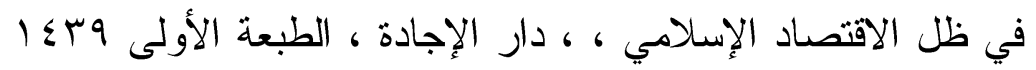

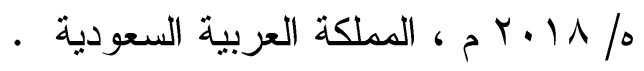

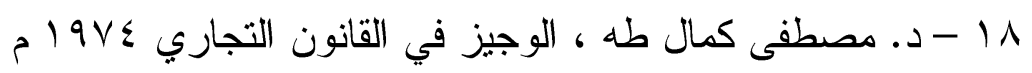

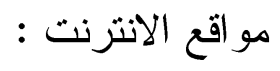

1-http://www.alukah.net/social/0/27156/\#ixzz5CehbwgQu

$2-/ /$ saudiwomen.wordpress.com/stats /

3 - www. Ahevar . org . 


\section{فهرس الموضوعات}

$\leqslant \vee$

مقدمة

$\varepsilon \vee Y$

التمهيد الدور التاريخي لممارسة المرأة التجارة

$\varepsilon \vee Y$

المطلب الأول ممارسة المر أة التجارة في العصور القديمة

المطلب الثاني الدور التاريخي لتجارة المر أة في نشر الدعوة الإسلامية 1؟

المبحث الأول عناية النظم الوضعية بأحقية المر أة في ممارسة التجارة بیى؟ المطلب الأول أحقية المر أة في ممارسة التجارة في المعاهدات و المو اثثق الدولية_AV؛ المطلب الثاني أحقية المر أة في ممارسة التجارة في النظم الداخلبة المبحث الثاني موقف الثريعة الإسلامية من ممارسة المر أة التجارة. ب9؟ المطلب الأول أحقية المر أة الغير مثزوجة في ممارسة التجارة في الثريعة الإسلامية و؟ المطلب الثاني أحقية المر أة المتزوجة في ممارسة تجارة منفردة عن زوجها في الثريعة الإنسلامية ب.

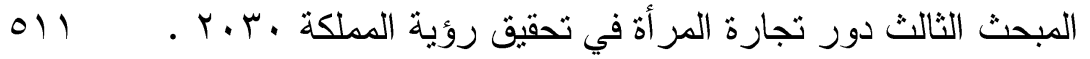
المطلب الأول عناية رؤية المملكة بتعاظم دور المر أة تجاريا 010 المطلب الثاني مساهمة تجارة المر أة في تحقيق الرؤية. or)

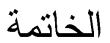

Orr

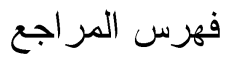
or. فهرس الموضو عات 